\title{
Advanced Functional Metal-Ceramic and Ceramic Coatings Deposited by Low-Pressure Cold Spraying: A Review
}

\author{
Marcin Winnicki (D) \\ Faculty of Mechanical Engineering, Wroclaw University of Science and Technology, 5 Łukasiewicza Street, \\ 50-371 Wroclaw, Poland; marcin.winnicki@pwr.edu.pl
}

check for updates

Citation: Winnicki, M. Advanced Functional Metal-Ceramic and Ceramic Coatings Deposited by Low-Pressure Cold Spraying: A Review. Coatings 2021, 11, 1044 https://doi.org/10.3390/ coatings11091044

Academic Editor: Salvatore Grasso

Received: 26 July 2021

Accepted: 25 August 2021

Published: 30 August 2021

Publisher's Note: MDPI stays neutral with regard to jurisdictional claims in published maps and institutional affiliations.

Copyright: (C) 2021 by the author. Licensee MDPI, Basel, Switzerland. This article is an open access article distributed under the terms and conditions of the Creative Commons Attribution (CC BY) license (https:/ / creativecommons.org/licenses/by/ $4.0 /)$.

\begin{abstract}
Based on the recent analysis of various databases, cold spray (CS), the newest method among thermal spraying technologies, has received the unabated attention of hundreds of researchers continuously since its invention in the 1980s. The significance of CS lies in the low process temperature, which usually ensures compressive residual stresses and allows for the formation of coatings on a thermally sensitive substrate. This paper concerns the low-pressure cold spray (LPCS) variant employed for forming metal matrix composites (MMCs) with high ceramic contents and all-ceramic coatings. At the very beginning, the influence of LPCS process parameters on deposition efficiency (DE) is analysed. In the next part, the most useful feedstock powder preparation techniques for LCPS are presented. Due to the combination of bottom-up powder production methods (e.g., sol-gel (SG)) with LCPS, the metal matrix that works as a binder for ceramic particles in MMC coatings can be removed, resulting in all-ceramic coatings. Furthermore, with optimization of spraying parameters, it is possible to predict and control phase transformation in the feedstock material. Further in the paper, differences in the bonding mechanism of metal-ceramic mixtures and ceramic particles are presented. The properties and applications of various MMC and ceramic coatings are also discussed. Finally, the exemplary direction of CS development is suggested.
\end{abstract}

Keywords: low-pressure cold spraying; ceramic coatings; multi-functional coatings; deposition efficiency; powders preparation methods

\section{Introduction}

Cold gas dynamic spraying, also known as kinetic spraying or simply cold spraying (CS), was originally developed in the mid-1980s as a coating deposition process by A. Papyrin and his team at the Institute of Theoretical and Applied Mechanics of the Russian Academy of Sciences in Novosibirsk [1]. Russian researchers reported several patents, including [2-4], and then published the first manuscript on CS in 1990 [5]. This invention was outstanding in the field of thermal spray technologies as the process enabled the deposition of solid-state metal particles. While improving the CS process, Papyrin's team successfully deposited a wide range of pure metals, metal alloys, and metal-ceramic composites on a variety of substrate materials and demonstrated the feasibility of cold spraying for various applications. To safeguard this innovative technology in other continents, a U.S. patent on CS was issued in 1994 [6], and a European one in 1995 [7]. Until now researchers all over the world have been developing the CS process and widening its applications.

CS compared to other thermal spraying techniques is characterized as a low-temperature process $[8,9]$. Thermal energy necessary for powder deposition is replaced in CS by kinetic energy. The working gas gains supersonic velocity in the de Laval nozzle and, due to drag force, accelerates the powder particles. The velocity can be controlled by the pressure and temperature of the gas. In addition, the process temperature increases the plasticity of the metal particles, enabling mechanical bonding. Nevertheless, the melting point of the applied powder material is not exceeded and thus the particles are sprayed in the solid state. Low thermal energy generates many benefits, such as: (i) high coating purity with 
low porosity or oxidation level [10,11], (ii) controlled phase transformation [12,13], (iii) uniform microstructure without grain growth $[14,15]$, (iv) possibility of coating of thermally sensitive substrates, e.g., polymers or aluminium moulds [4], as well as (v) relatively low and mostly compressive residual stresses resulting from the tamping effect of impinging solid particles [3].

Several parameters are influencing the CS process, including, powder and substrate material, particle morphology, oxidation level and spraying temperature, which decide about the coating formation and deposition efficiency as well $[8,9,16]$. However, a key parameter is the velocity of the particles resulting from the geometry of the spray gun nozzle, the type of working gas, and its temperature and pressure [17-19]. Therefore, the particles have to exceed the so-called critical velocity for a successful deposition. With velocities lower than a critical one, particles will abrade the substrate and rebound. Starting with the critical limit, which depends on the process parameters, particle adhesion to the substrate occurs. However, when the velocity is too high, the particles will provide strong erosion of the substrate [19-26]. High-pressure cold spraying (HPCS), as a more advanced method with high performance, is suitable for various ranges of metals. Simultaneously, it is stated that the application of low-pressure cold spraying (LPCS) compared to HPCS is significantly limited to easy-plastic-deformable materials such as tin, zinc, copper, aluminium, and nickel. The presented division results from process parameters and can be extended in the case of LPCS by proper powder modifications, e.g., ceramic to metal powder addition, two or more metal powder mixtures [27-29].

It is worth emphasising that CS was initially developed for spraying ductile metal powders due to the necessity of plastic deformation upon solid particles impact on the substrate. Therefore, mainly metals and various mixtures of metals and metal with ceramics were applied as feedstock powders $[1,10]$. The basic function of ceramic powder is to improve the mechanical and physical properties of the coating. The incoming hard particles cause peening and additional work hardening of metal particles, and thus coating densification, reinforcement, and grain refinement [30,31]. Parts of ceramics are crushed and wedged mechanically or interlocked by the soft matrix providing dispersion strengthening [32]. As a result, CS composite coating microstructures are composed of a highly deformed matrix and non-deformed reinforcement. Simultaneously, ceramic powder supports the deposition process by the following: (i) eliminating the nozzle clogging in spray gun models without water cooling $[28,33,34]$, (ii) activation of the surface by removing the oxide layer and contamination [35-37], and (iii) roughening the surface increasing contact area $[37,38]$. On the other hand, the application of pure ceramic powder in CS usually requires a "soft" matrix. According to the latest research results, the proper preparation of ceramic powders ensures successful deposition. The mechanism based on plastic deformation can occur in ceramics. However, fine particles must be applied [39,40]. What is more, the velocity of nanosized ceramic powder can be increased by particle agglomeration. Appropriate powder production methods, e.g., spray drying or sol-gel, provide residues of organic additives, which work as a binder. Finally, nanosized agglomerated particles due to fragmentation will bond to the substrate.

Except for low process energy, typical advantages of the CS process include also high deposition efficiency, in situ micro-grit blasting, flexible substrate-coating materials combination and low process costs $[41,42]$. Moreover, deposited coatings are usually characterized by high density and wide thickness range, as well as improved electrical and thermal conductivity, corrosion resistance, strength, and hardness [41,43,44]. On the other hand, the main disadvantages that must be challenged include low toughness [41,45], ductility $[46,47]$, and cohesion $[48,49]$. As a result, some applications may require postspraying heat treatment (PSHT) [47,50]. A great opportunity for further development of the CS is the fabrication of nanostructured MMC and ceramic coatings. An optimized nanocrystalline powder material and the parameters of the spraying process provide many benefits, such as simultaneously high mechanical properties and high toughness [51,52], superior thermal and electrical properties [53], excellent transparency [50], or improved 
photocatalytic efficiency [54]. These improvements can be achieved in CS coatings by tailoring the composition and microstructure of the composite or ceramic powder. However, the control of nanostructures in the coating via powder preparation and processing parameters remains a challenging issue.

After three decades of worldwide research on the CS process, more and more unique functional materials (such as composite or ceramic nanomaterials) are being found, increasing the possible range of applications. LPCS seems to be especially promising as an economic, mobile, safe and easy-to-operate system. Within the presented paper, modern applications of LPCS divided into metal-ceramic composite and al-ceramic coatings are discussed.

\section{LPCS Deposition Efficiency}

It is commonly known that HPCS has superior deposition efficiency (DE) over LPCS due to significantly higher process parameters (e.g., pressure and temperature). Taking aluminium powder as an example, the DE equals $95 \%$ for HPCS [25] and 7\% for LPCS [48,55]. As one may guess, additive manufacturing using LPCS has very limited capabilities. LPCS, however, has several advantages over HPCS from an economical point of view, concerning gas consumption, installation and maintenance cost $[1,25,27]$. Therefore, optimization of LPCS process parameters using commercially available or self-synthesized powder materials provides access to the advanced functionalization of substrate surfaces for various applications in many industrial fields.

A basic method to improve the DE in LPCS is mixing soft metal powder with hard phase, e.g., ceramic powder, which provides a tamping effect and increases plastic deformation [48]. As a result, more metal powder will be embedded with additional ceramics. Nevertheless, the size of the ceramic particles in the mixture significantly affects the DE of the powder. Sova et al. [56] found that only fine ceramic particles in powder significantly increase the DE of the metal component due to the roughening, cleaning, and mechanoactivating of the surface or previously sprayed metal particles. What is more, coarse particles decrease the DE due to lower velocity and enhanced erosion of the surface [57]. On the other hand, the particle mass loading influences significantly their acceleration by working gas. By using numerical calculations and experimental verification, Meyer et al. [58] revealed that increasing the feed rate up to $120 \mathrm{~g} / \mathrm{min}$ caused a decrease of particle velocity of $14 \%$. It is worth emphasising that in LPCS the most popular feedstock are powders mixtures with a particle size of 5-50 $\mu \mathrm{m}[59,60]$. The DE of particles out of the range is limited due to lower velocity. It results from high mass or deceleration in the bow shock region for larger and smaller particles, respectively. Another factor influencing DE is metal powder shape. Dendritic or irregular metal particles deform easier than spherical [61]. Application of spherical and dendritic copper powder in LPCS resulted in DE = $6.9 \%$ and $28.6 \%$, respectively [62]. Further admixture of hard phase to dendritic powder increases DE to 35.8\%. Melendez and McDonald [63] sprayed tungsten carbide (WC) +4 wt.\% Ni powder mixture and obtained DE of WC equal to $68 \%$. It is generally stated that DE of LPCS remains low and does not exceed $40 \%$ with common process parameters [64]. However, there are other more demanding methods to increase DE based on application, including laser-assisted cold spray process [65], powder feedstock oxide reduction before spraying [66,67], long preheating of the powder feedstock [21], additional heating of the substrate during spraying [61,68], as well as utilizing another working gas instead of air $[61,68,69]$.

It is advisable to start the DE optimization with proper LPCS process parameters selection. The parameters can be categorized into four main types [70]: gas parameters, nozzle geometrical parameters, particle parameters, and substrate parameters (Figure 1). Those parameters influence the critical velocity of particles. According to the literature, the deposition efficiency is determined by the ratio of particle exit velocity to the critical velocity [26,69]. As a result, using a proper mathematical model, the DE can be calculated [5]:

$$
\mathrm{DE}=0.0019 \mathrm{~V}_{\text {particle }}-0.8934
$$




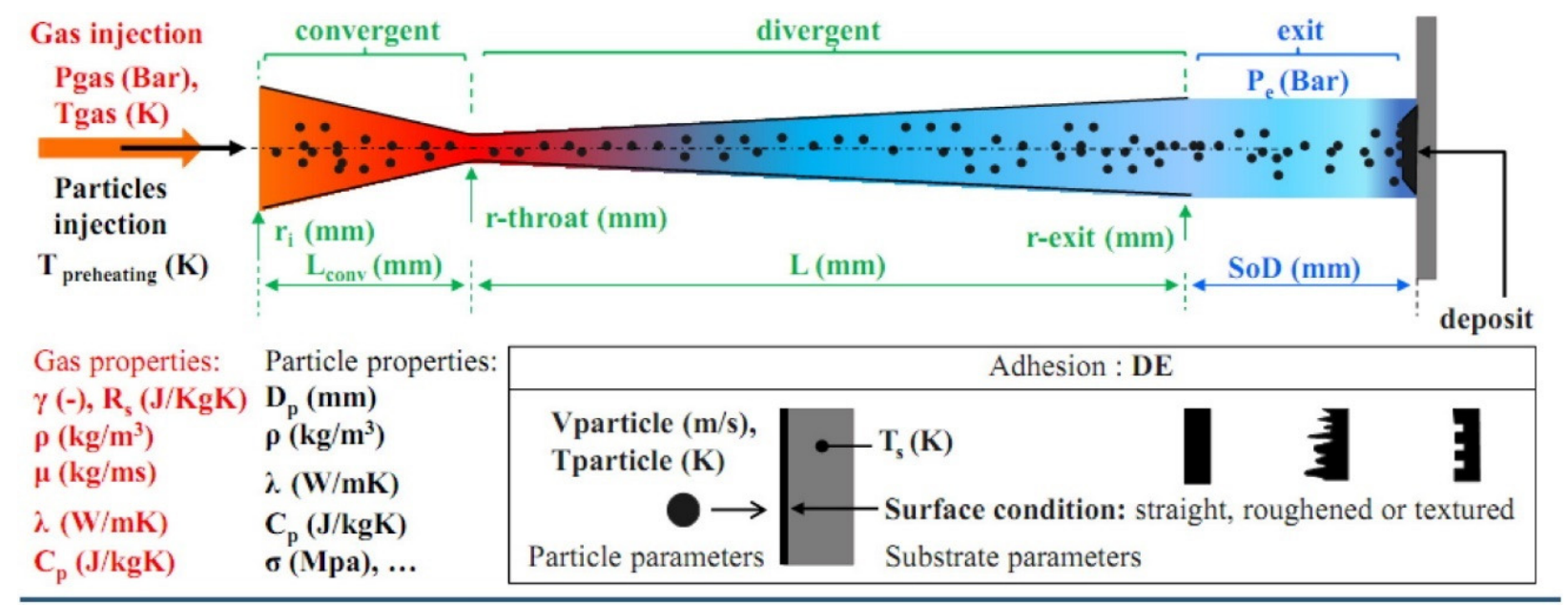

Computational procedure for the DE prediction

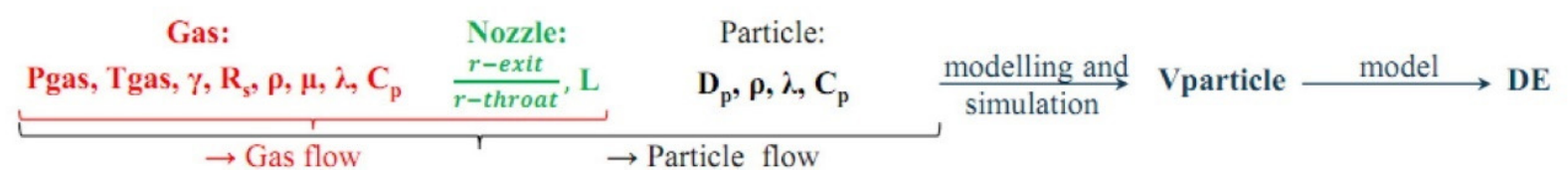

Figure 1. Major CS process parameters and computational procedure of the DE. Reprinted with permission from [69]. Copyright 2016 Elsevier.

Raoelison et al. [69] applied 1-D computing tests of the gas flow through the de Laval nozzle and by the interaction with the particles identified potential solutions to increase the DE. Using air as a propellant gas set at $10 \mathrm{bar}$ and $630^{\circ} \mathrm{C}$ and particles with a diameter higher than $10 \mu \mathrm{m}$, resulted in the maximum DE of $20 \%$ (see Figure 2). What is more, particles with a diameter above $15 \mu \mathrm{m}$ will rebound. To increase the DE up to $90 \%$ or more, LPCS parameters, such as particles size, working gas, nozzle length, and expansion ratio, should be adjusted (Table 1). Nevertheless, according to Raoelison et al. [69], the highest influence has the working gas. Helium, compared to nitrogen and air, remains the most efficient gas due to its high specific gas constant. It is worth emphasizing that the standoff distance $(\mathrm{SoD})$ of the nozzle to the substrate is crucial for particles velocity and should be between 5 and $15 \mathrm{~mm}$. When the SoD increases, the gas velocity decreases due to viscous effects at the spraying jet periphery. However, the gas velocity remains supersonic for the longest time at the centre of the jet, since here the gas velocity is highest [70] (Figure 3).

Table 1. Influence of LPCS parameters on the DE (inspired by Raoelison et al. [69]).

\begin{tabular}{ccc}
\hline LPCS Process Parameter & Positive Impact (Advantages) & Negative Impact (Disadvantages) \\
\hline $\begin{array}{c}\text { Decrease of the particles size below } 3 \mu \mathrm{m} \\
\begin{array}{c}\text { Change the nozzle expansion ratio } \\
\text { (r-exit/r-throat): 1.2-2.0 }\end{array}\end{array}$ & High DE, up to 70\% & $\begin{array}{c}\text { Tend to stick on the nozzle wall } \\
\text { and cause clogging }\end{array}$ \\
\hline $\begin{array}{c}\text { Increase the length of the diverging part } \\
\text { of the nozzle from } 130 \text { to } 400 \mathrm{~mm}\end{array}$ & $\begin{array}{c}\text { For the particle diameter of } 10 \mu \mathrm{m}, \mathrm{DE} \\
\text { increase from } 20 \% \text { to } 50 \%\end{array}$ & $\begin{array}{c}\text { Long nozzle may cause: } \\
\text { (ii) bending of the overheated nozzle }\end{array}$ \\
\hline Apply helium as working gas & $\begin{array}{c}\text { Helium alone enables a great increase of } \\
\text { DE due to its high specific gas constant }\end{array}$ & Extremally higher costs of the process \\
\hline
\end{tabular}



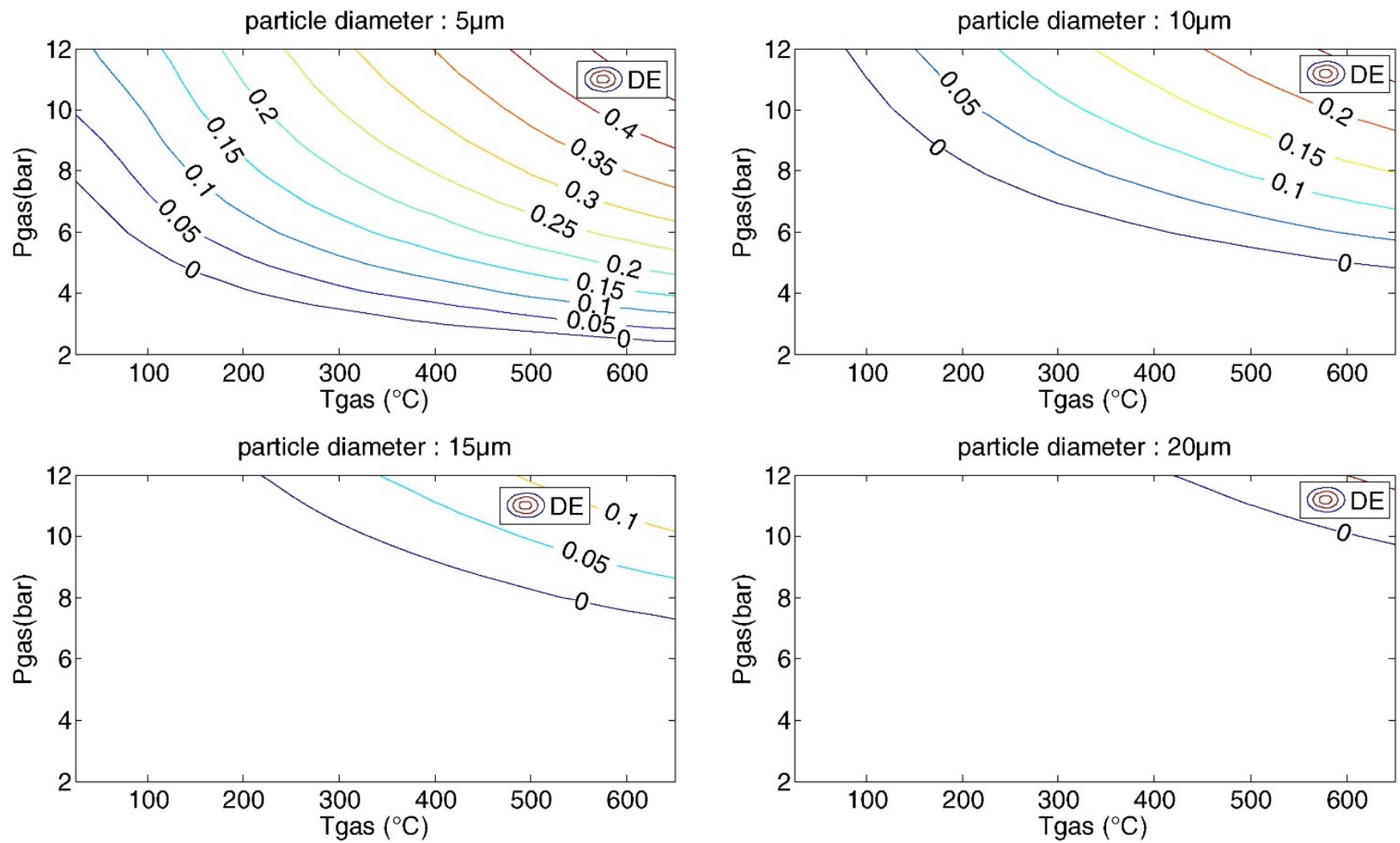

Figure 2. Computed DE for an air pressure range of 2-12 bar, a gas temperature range of $20-630{ }^{\circ} \mathrm{C}$, and a particle diameter of 5, 10, 15 and $20 \mu \mathrm{m}$. Reprinted/Adapted with permission from [69]. Copyright 2016 Elsevier.

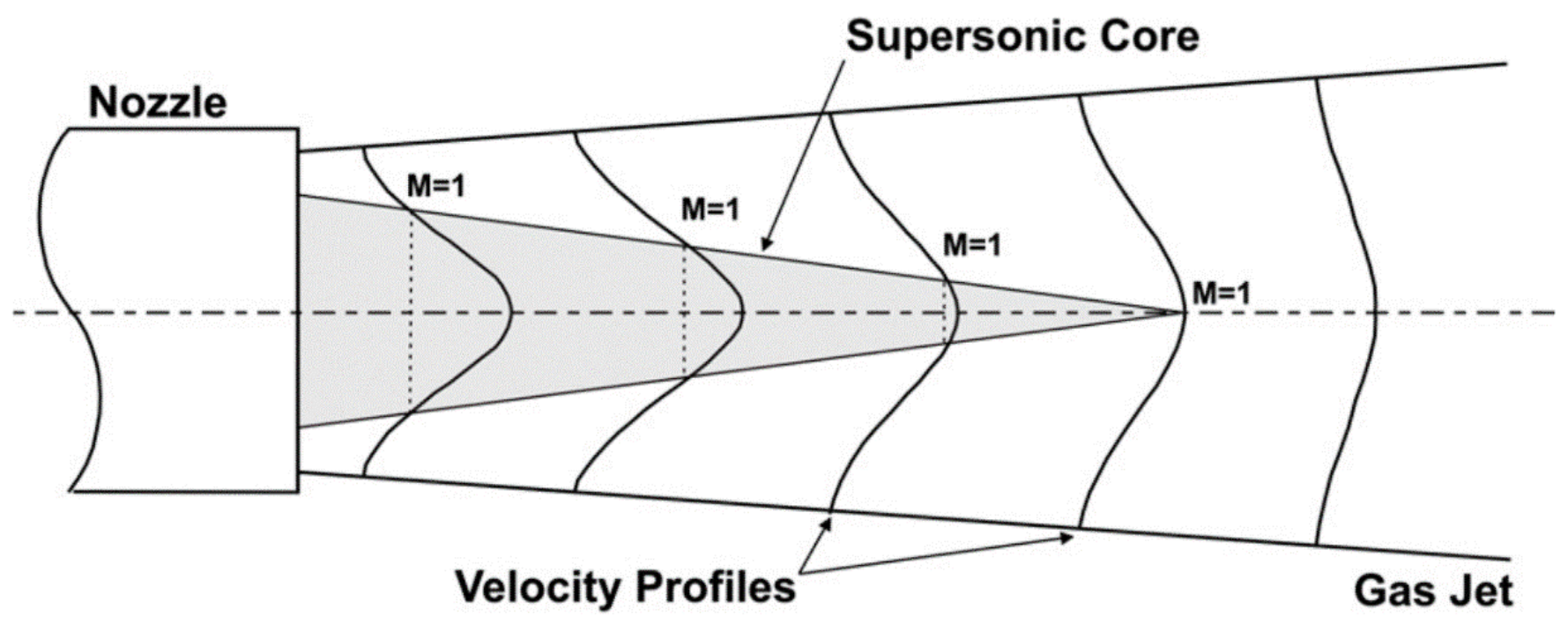

Figure 3. Schematic representation of a nozzle's supersonic core. Reprinted with permission from [70]. Copyright 2008 Elsevier.

It is well known that the higher velocity of impacting metal particles in CS the higher deformation and DE [70]. However, the velocity should not exceed erosion velocity, in which substrate degradation occurs (Figure 4). The range between critical velocity and erosion velocity restricts a deposition window. It is visible in Figure 4 that the range is broad for ductile metals. What is more, Schmidt et al. [71] concluded that brittle materials (e.g., ceramics) would cause erosion for any velocity as long as their temperature is below the melting point. Kliemann et al. [72] tested HPCS to spray $\mathrm{TiO}_{2}$ coating on various 
ductile metal substrates and found that the deposition of ceramics could be possible for ductile substrates that allow for the activation of shear instability in metal. Nevertheless, due to the high energy impact, the fracture of the brittle particles leave only small particle fragments on the substrate surface. The subsequent coating layers can be deposited on the condition that pieces of metal detached from the substrate would act as a binder for ceramics. Consequently, the thickness of the ceramic coating is limited due to difficulties with delivering metal particles from the substrate.

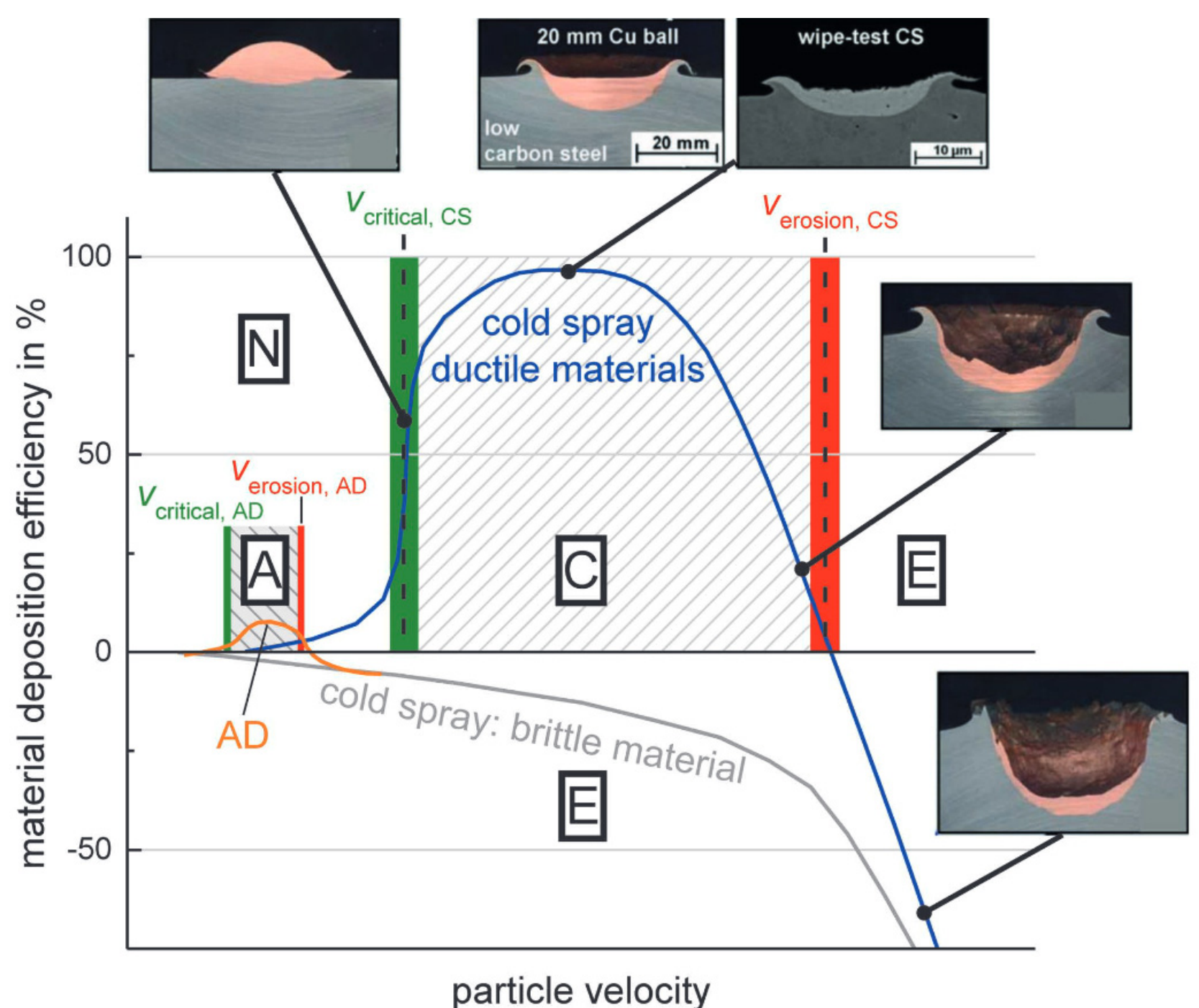

Figure 4. "Deposition Window" for ductile (CS) and brittle (AD) materials as a DE vs particles velocity function. Areas: A-AD deposition window, C-CS deposition window, E-substrate erosion (too high particles velocity) or ceramics application in $\mathrm{CS}, \mathrm{N}-$ no deposition [73].

The deposition of pure ceramic particles is possible by a method similar to LPCS known as aerosol deposition (AD) [73]. The process parameters include lower working gas stagnation pressure, ambient temperature without heating and nanosized ceramic particles. As a result, lower particle velocities are obtained. Nevertheless, the deposition is possible owing to the controlled atmosphere as the process is run in a vacuum. Therefore, compared to CS, AD uses significantly lower pressure ranges, 60-1066 mbar [74]. Glosse et al. [75] analysed the influence of process parameters on DE in AD to conclude that higher chamber back pressures (10-20 mbar) decrease film thickness, despite the working gas stagnation pressure maintained in the range of 319-558 mbar. The pressure in the 
vacuum chamber has to be much lower than the nozzle exit pressure to produce a highly under-expanded supersonic jet. Therefore, the applied vacuum has a significant influence on the process and simultaneously preclude this procedure to be implemented for HPCS or LPCS in an air atmosphere. Furthermore, according to Glosse's results [75], increasing gas flow rates increases the kinetic energy of the impacting particles, resulting in a highly abrasive effect of particles on the coating, decreased DE, and finally thinner deposited layers. According to Hanft et al. [74] and Akedo [76], critical velocities also exist for AD and depend on the material of the ceramic particles and the substrate (Figure 4). Similar to CS of metal powder, the ceramic particles should not exceed erosion velocity, otherwise the powder will grit-blast the substrate, fracture, and bound off. Akedo [76] found that the critical velocity of nanosized ( $300 \mathrm{~nm}$ particles diameter) $\alpha-\mathrm{Al}_{2} \mathrm{O}_{3}$ particles was $150 \mathrm{~m} / \mathrm{s}$. It arises from small particles sizes, their agglomeration and applied vacuum. Therefore, DE depends not only on particles velocity but also on the substrate material, nature of the aerosolized particle and their distribution [73]. It appears that the same parameters are responsible for successful coating fabrication via LPCS. However, in LPCS, the stream of ceramics has to overcome the air atmosphere, which decelerates the particles, and thus requires higher velocity compared to AD. Particles velocity in LPCS can be increased by modifying the morphology of the particles. In my previous research [61], I concluded that the velocities of copper dendritic particles were much higher than spherical ones. It arises from higher drag coefficient of irregular particles [21]. Therefore, the agglomeration of ceramic particles increases the velocity of nanosized powder. What is more, nanosized agglomerated particles due to fragmentation will bond to the substrate. The methods of ceramic powder preparation for LPCS process and bonding mechanics are described in further parts of the manuscript.

\section{Metal Matrix Composite Coatings}

Particle reinforced metal matrix composite (PRMMC) coatings consist of a ductile matrix (pure metal or metal alloy) and hard reinforcement phase (different metal, ceramics, intermetallic phase, organic or inorganic material), and as a result, combine properties of both materials, e.g., resistance for high-temperature mechanical loading, maintaining increased durability $[77,78]$. Due to high strength, hardness, chemical inertness, high melting point, and many functional applications, ceramic powder is the most commonly selected material for reinforcement in PRMMC coatings [77,79-82]. The uniformly distributed, coherent, and continuous hard phase in the metallic matrix increases the following properties of the coating: (i) mechanical properties, such as strength, elastic modulus, hardness, and wear resistance [81,83,84], (ii) chemical properties, including corrosion resistance [62,82,83], and (iii) physical properties, e.g., high-temperature stability [79,85], or electrical and thermal conductivity [62,86-88]. Among other thermal spraying techniques, CS ensures a solid state of PRMMC coatings deposition, without tensile thermal stresses, phase transformation, decarburization, oxidation, or high porosity $[28,48,89,90]$. The low cost of commercially available powder mixtures and easy control of coating composition makes PRMMC coatings an attractive alternative for complex alloys.

Metal particles in CS impact the substrate with high kinetic energy and as a result undergo severe plastic deformation at a high strain rate [18,61]. Strong pressure waves interact with the expanding edge of the particle forming a jet, which is prone to localized fragmentation under a spall-like process [91]. Additionally, the temperature may increase locally in the particle boundary region and cause adiabatic shear instability [61,92]. Despite the low temperature of the process, the flow of metal and jet formation occurs. This phenomenon favours the adhesion and cohesion of the particles. What is more, the deformation is increased in PRMMC by the tamping effect of hard ceramic particles. Therefore, despite lower particles velocities obtained in LPCS, ceramic powder ensures additional work hardening of the metal particles and significantly increases the mechanical properties of the PRMMC coating. 


\subsection{Powders Preparation}

In the CS process, PRMMC coatings are deposited as a mixture of two or more metalceramic powders. The powders mixture can be prepared by several methods illustrated in Figure 5, such as: (i) mechanical blending of powders, offering simple operation and easy control over the composition of the composite powder $[82,93,94]$, (ii) satelliting, to improve dispersion of the small reinforcing particles by the formation of satellites on the surface of large particle of second phase [95,96], (iii) powder cladding to form a continuous and uniform metal coating on the ceramic powder and increase control of the volume fractions of the hard phase [68], (iv) mechanical ball milling to improve the distribution of reinforcement phases with control of size and content of mixed phases [97,98], (v) ball milling combined with self-propagating high-temperature synthesis or annealing in controlled atmosphere to obtain a modified structure, and (vi) spray drying to facilitate the atomisation of slurry followed by drying in hot gas, agglomeration, and sintering, which ensures homogeneous, agglomerated composite powders [99,100]. Selecting a proper mixture preparation method should be matched with matrix phase and reinforcement phase, and most importantly with mixture application. In thermal spraying processes, various powders can react differently, e.g., high temperature causes decarburization, high plastic deformation leads to a decrease of DE, etc. All the methods are compared in Figure 5 and are precisely described below.

The blending of powders is the simplest and cheapest way to prepare the mixture and various materials with a high range of particles sizes that can be used in the process. Many commercially available powders for LPCS are prepared this way, including Al$\mathrm{Al}_{2} \mathrm{O}_{3}[48,93,101], \mathrm{Cu}-\mathrm{Al}_{2} \mathrm{O}_{3}[62,102,103]$ (Figure 6), $\mathrm{Zn}-\mathrm{Al}_{2} \mathrm{O}_{3}$ [81,102,104], $\mathrm{Sn}^{-\mathrm{Al}_{2} \mathrm{O}_{3}}$ [81, $105,106], \mathrm{Ni}-\mathrm{Al}_{2} \mathrm{O}_{3}[68,81,102]$, and other powder mixtures for special application, such as $\mathrm{Cu}-\mathrm{SiC}$ [82,107], Al2319-TiN [108], and WC-Ni [80]. Due to their higher kinetic energy,

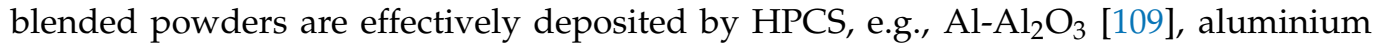
alloys: $\mathrm{A} 380-\mathrm{Al}_{2} \mathrm{O}_{3}$ [110,111], $\mathrm{AA2024}-\mathrm{Al}_{2} \mathrm{O}_{3}$ [112], $\mathrm{Al5056-SiC} \mathrm{[113],} \mathrm{Cu}-\mathrm{CuO}_{2}$ [114], and $\mathrm{Ni}-\mathrm{B}_{4} \mathrm{C}$ [115]. It should be emphasised that increasing differences in the particle size, morphology, or density of mixed powders result in various ranges of particles velocities. As a result, mixed materials show divergence in DE and, in consequence, nonuniform material distribution in the deposited coating [116]. What is more, particles size range should be above $5 \mu \mathrm{m}$, as smaller particles decelerate in the bow shock formed above the substrate [98]. Therefore, another method was proposed, known as satelliting. In this process, two powders with various particles sizes are mixed in liquid binder [95] or lowenergy vibration mill $[117,118]$ (Figure 6). As a result, small particles of the first phase form satellites on the surface of the second phase particles due to the action of van der Waals force. However, such a weak adhesion causes easy separation during satellite impact and usually some part of reinforcement rebounds. Al-Hamdani et al. [119] mixed Al powder (15-45 $\mu \mathrm{m}$ size range) and TiC powder (particle size $<5 \mu \mathrm{m}$ ) in a tubular mixer with the addition of a binder. Afterwards, the powder was dried at $100{ }^{\circ} \mathrm{C}$ for $12 \mathrm{~h}$. Al-Hamdani et al. noticed the more evenly distributed $\mathrm{TiC}$ in the satellited feedstock, and subsequent more steady flow during spraying, compared to blended powders. As a result, a high proportion of ceramic that was attached to the satellited powder was embedded in the coating. 


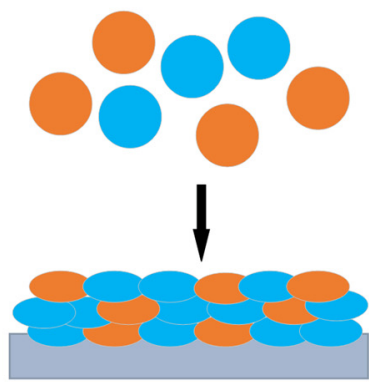

A:

- low cost and easy operation,

- no reactions,

- various material's combinations

\section{D}

- nonuniform components distribution,

- no bonding between components,

- feeding problems
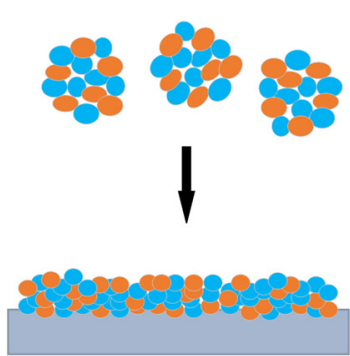

A:

- homogeneous components

distribution,

- effective size control,

- strong bonding between components

D:

- complex parameters optimization

- particle shape and oxidation control

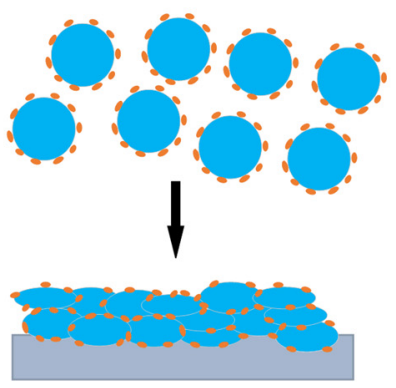

A

- increase of hard phase small particles fraction area,

- more uniform particles distribution

D

- particles dispersion problems

- poor interface bonding of smaller particles
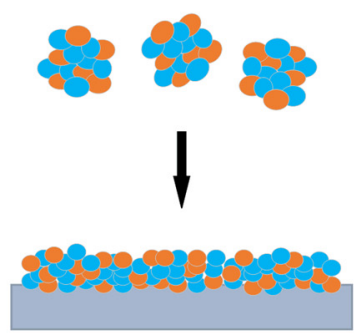

- dedicated for cermets, e.g. WC-Co, - near spherical morphology

D:

- powders density depended on many parameters, e.g. powders morphology,

- high production costs

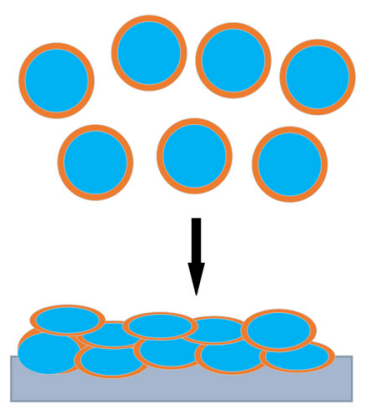

A

- volume fraction regulation by coating layer thickness,

- composite powders with single or multiple hard phase regulation

D:

- thickness optimization needed,

- complex process with high costs
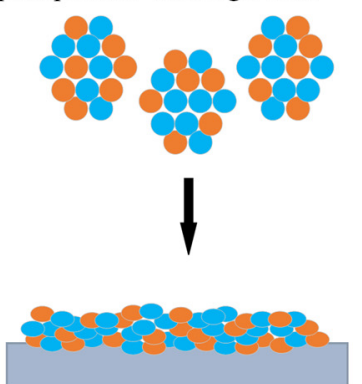

A:

- homogeneous agglomerated powders mixture,

- high control of particles size and oxidation level

D

- poor bonding between components, - high process costs and low production efficiency

Figure 5. Comparison of different powder preparation methods and schematic deposition onto the substrate: mechanical blend (upper left), satelliting (upper middle), powder cladding (upper right), mechanical ball milling (lower left), ball milling with SHS or annealing (lower middle) and spray drying (lower right). Blue and orange colours mean various phases. A—advantage, D—disadvantage (inspired by [98]). 


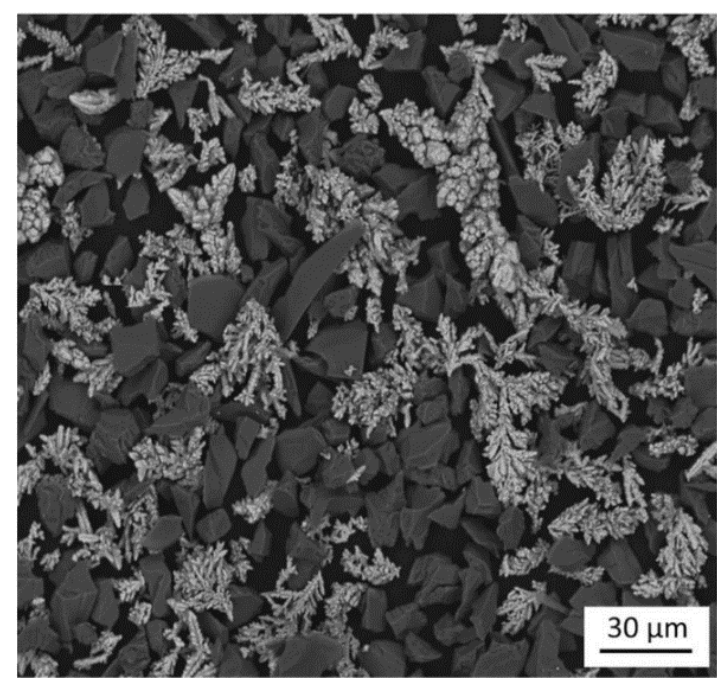

(a)

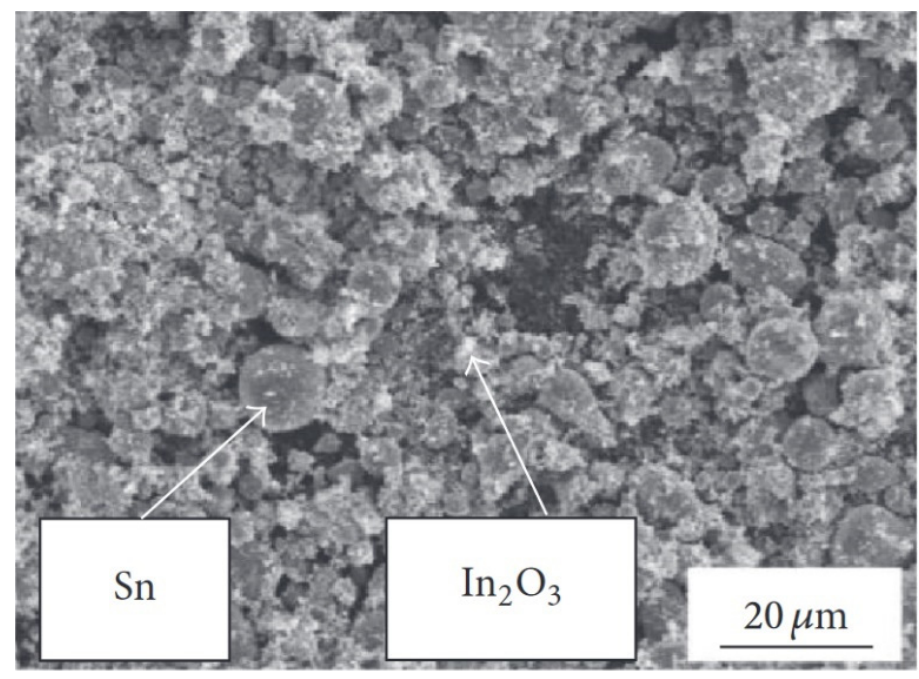

(b)

Figure 6. Mechanically blended $\mathrm{Cu}+\mathrm{Al}_{2} \mathrm{O}_{3}$ powder (a) (Reprinted with permission from [82]. Copyright 2017 Springer Nature) and satellited $\mathrm{Sn}+\mathrm{In}_{2} \mathrm{O}_{3}$ powder (b) [117].

Powder cladding can be used to increase the amount of ceramic in the coating. Within the process, the selected metal is coated on a hard phase with defined thickness to obtain a desired fraction of ceramic material $[68,120]$. The method is dedicated to manufacturing cladded powders and mainly includes [68]: (i) immersion coating; (ii) electroless chemical plating; (iii) electrolytic deposition; (iv) mechanical coating; (v) chemical vapor deposition (CVD); (vi) physical vapor deposition; and (vii) hydrothermal hydrogen reduction method. By selecting the appropriate process and its optimal parameters, the thickness of the coated layer can be regulated. Deposited metal works as a binder and joins particles of hard phase to agglomerates [120] (Figure 7). The process enables the deposition of a coating with a high and controlled volume fraction of the hard phase. However, CS requires a metal matrix to spray any hard particles, including ceramics. Therefore, the thickness of the clad layer should be sufficient to ensure particle adhesion [68]. It should be noted that the reinforcing phase can be cladded on the metal particles. Okimura et al. [121], to increase hard phase in the LPCS coatings, proposed the deposition of diamond-like carbon (DLC) films on the surface of Ti and $\mathrm{Cu}$ powders by (CVD). Meanwhile, Wang et al. [122] encapsulated aluminium powder particles with graphene to increase the corrosion resistance of the coating.

One effective way to increase the volume fraction of hard particles in the composite is mechanical ball milling. It solves the problem with various sized particles bonding. The process parameters (including ball-to-powder ratio, milling speed, time, and atmosphere) ensure control on the content and distribution of mixed phases and increases material uniformity [123] (Figure 8). A high energy ball mill is beneficial to the plastic deformation, work hardening, and refining of metal-ceramic composite powders into small particles, and hence improves the distribution of submicron or nanosized ceramic particles [124]. Luo et al. [125] found that the grain size of the $\mathrm{NiCrAl}$ matrix in the cBN-NiCrAl composite powder prepared by mechanical alloying decreased to a few tens of nanometres with increasing mechanical alloying duration (Figure 9). However, to retain these features of powders in the as-sprayed coatings, a low-temperature process, such as cold spraying, has to be used. Salur et al. noticed that by setting milling time, the lattice strain, dislocation density and $\mathrm{Al}$ crystallite size can be controlled in the mixture with $\mathrm{TiC}$ nanoparticles (see Figure 10) [126]. Many studies reported increased coating quality and properties, such as bond strength [127] or hardness [128]. Nevertheless, the high energy of the mill produces enhanced work hardening of the ductile phase [129] or particles cold-welding into multi-agglomerates [117]. Consequently, the DE of the mixture can be decreased, and 
the uniformity of materials deteriorated. Therefore, this preparation method is dedicated for HPCS $[128,130]$. What is more, mechanical treatment can be combined with selfpropagating high-temperature synthesis (SHS) to produce fine and controlled hard phase particles in a metal matrix. Kim et al. [131] mixed in ball mill powders of Ti, B and $\mathrm{Cu}$ to obtain $\mathrm{TiB}_{2}-43$ vol.\%-Cu nanocomposite powder with the ceramic particle of size 50-100 $\mathrm{nm}$. The SHS reaction was uniform in the mixing powder volume due to the high thermal conductivity of copper. Neri et al. [132] coupled the SHS synthesis with high-energy ball milling to prepare nanostructured solid solutions for oxygen-sensing applications. A series of SrTi1 $-\mathrm{xFexO}-\delta$ (STO or STFO) perovskite powders, with $\mathrm{x}$ ranging from 0 to 0.6 were prepared to start from $\mathrm{SrO}_{2}, \mathrm{Ti}, \mathrm{TiO}_{2}$ and Fe powders mixture. Based on the reported data Neri et al. concluded that the ball milling combined with SHS reaction: (i) stabilizes the formation of non-equilibrium structures; (ii) decreases the particle size, increases surface defects and hence surface reactivity; and (iii) favours the substitution of titanium by iron in the $\mathrm{SrTiO}_{3}$ perovskite structure. Vasanthakumar et al. [133] mixed metal powders (Ti, W, Ta, $\mathrm{M}, \mathrm{V}$ ) in equimolar proportions and with carbon black to synthesize high entropy carbide (HEC) compact by reactive spark plasma sintering of ball milled metal-carbon elemental mixture. High-energy ball milling significantly reduced the sintering temperature of the powder.

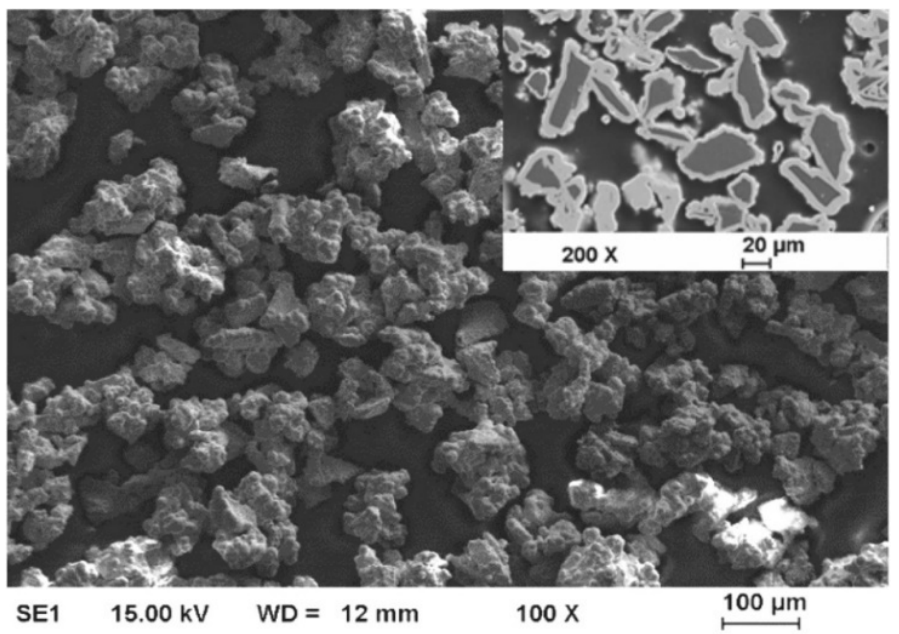

(a)

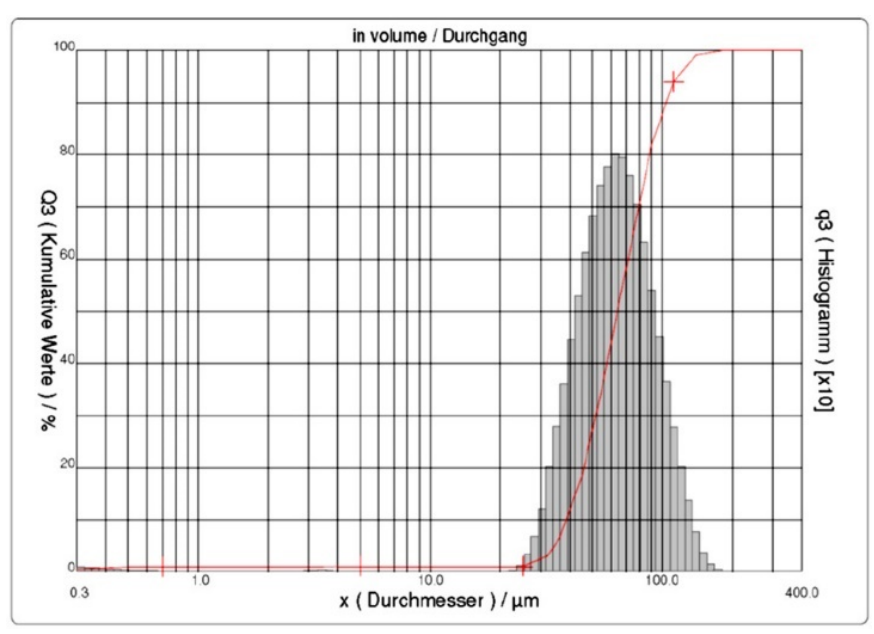

(b)

Figure 7. Nickel cladded alumina powder agglomerates fabricated by hydrothermal hydrogen reduction: SEM (SE) micrograph of powder (a) and particles' size distribution (b) Reprinted with permission from [68]. Copyright 2021 Elsevier. 


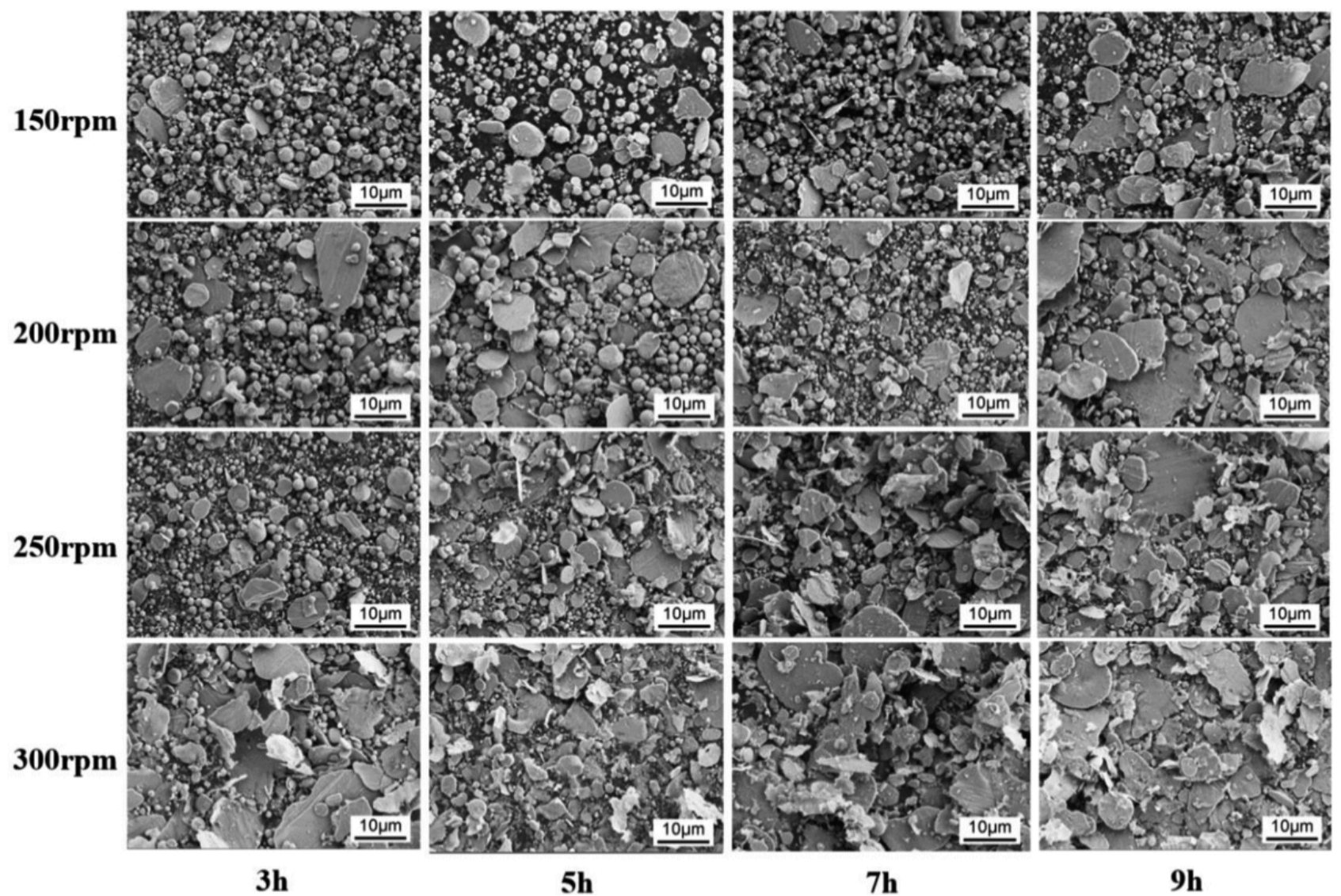

Figure 8. Micrographs (SEM, SE) of mixed $5 \mathrm{wt} \%$ nano-diamond reinforced 2024Al alloy composite powder fabricated under different ball milling conditions: the ball milling speed and process time. Reprinted with permission from [124]. Copyright 2021 Elsevier.

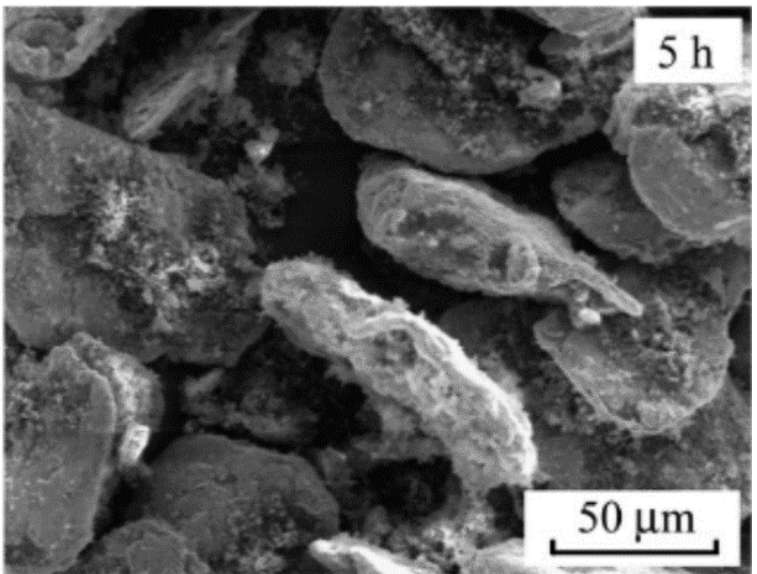

(a)

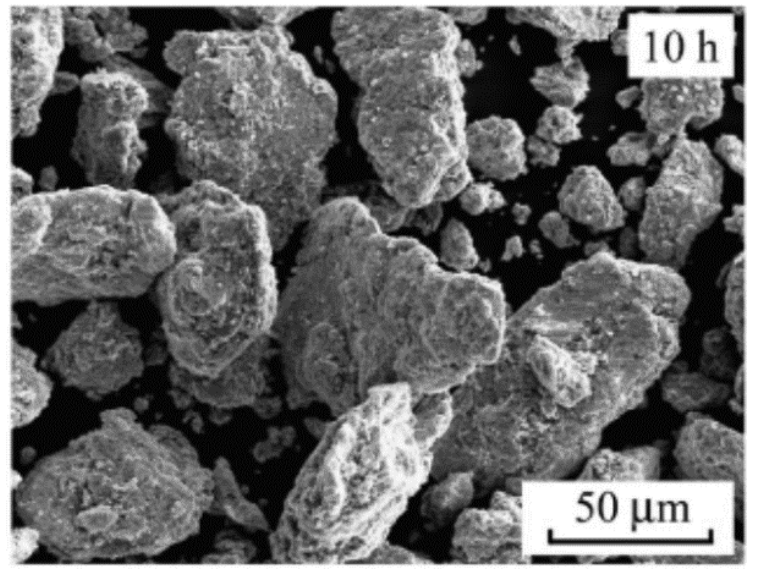

(b)

Figure 9. Cont. 


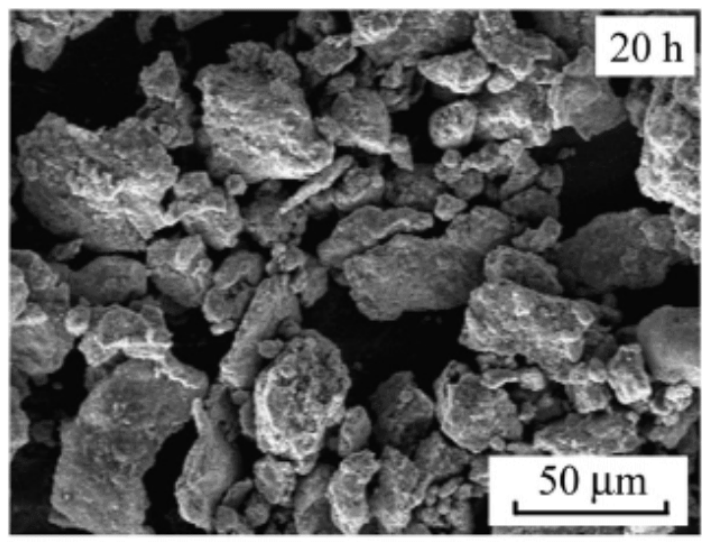

(c)

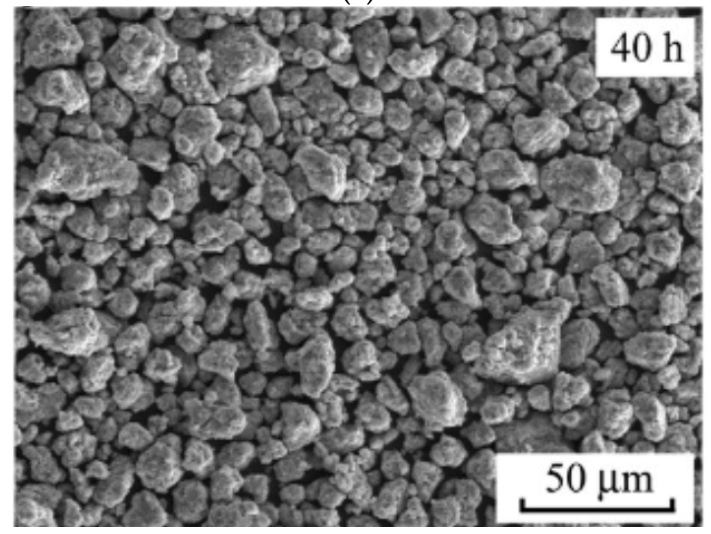

(e)

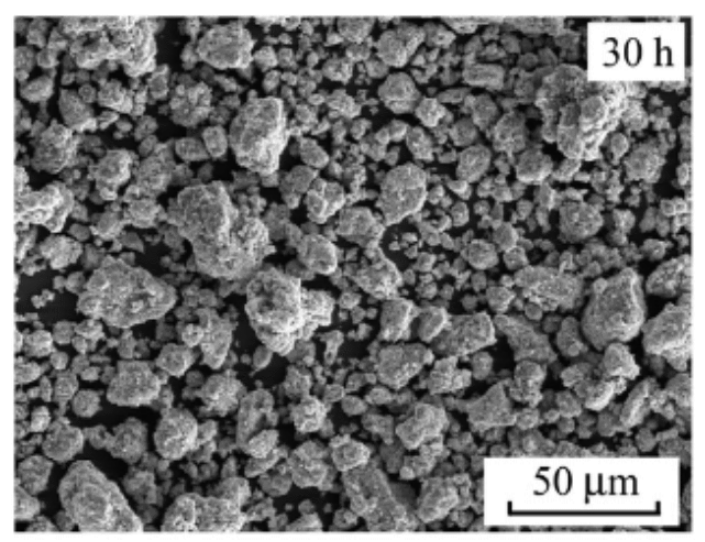

(d)

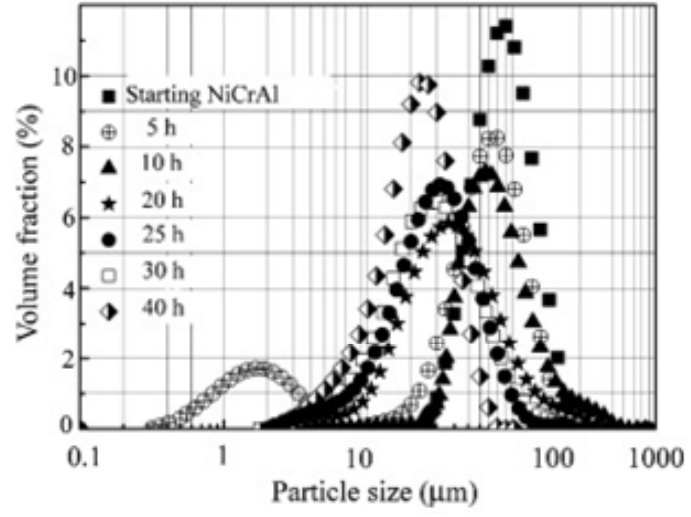

(f)

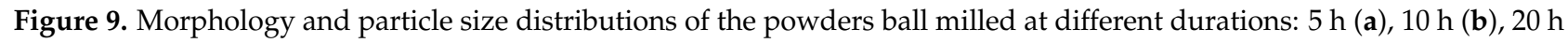
(c), $30 \mathrm{~h}(\mathbf{d}), 40 \mathrm{~h}(\mathbf{e})$, the particle size distributions (f). Reprinted with permission from [125]. Copyright 2012 Elsevier.

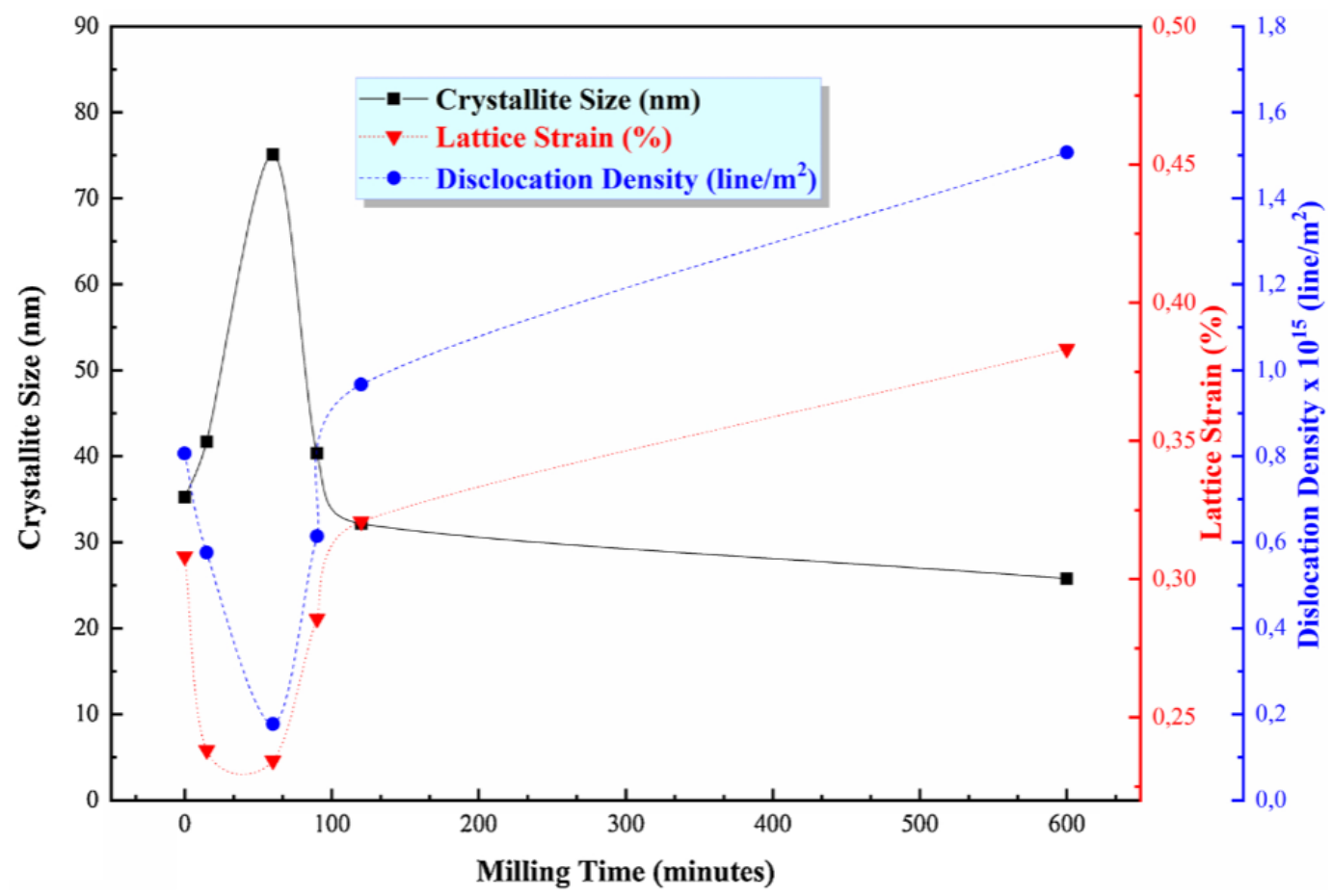

Figure 10. The variation of the crystallite size, lattice strain, and dislocation density of TiC/AA7075 powders estimated from XRD curves. Reprinted with permission from [126]. Copyright 2021 Elsevier. 
Another method enabling the production of homogeneous nanostructured composite powder from submicron or nano-sized particles is spray drying. The process includes the following stages: (1) raw powders mixing to prepare slurry with the use of binder, (2) atomization of the slurry to fabricate composite powders and (3) heat treatment (also called calcination) of prepared powders. A wet ball milling can be used to blend the nano-sized particles homogeneously [134]. After atomization of the slurry, micro-sized nanostructured composite powders are received. However, powder morphology depends strongly on the spray drying process parameters, such as the rotating speed of nozzle, as well as inlet and outlet temperature. The final particle size and degree of sphericity of the as spay dried powders is affected by the rotating speed of the nozzle. Higher rotating speed promotes the refinement and the sphericity of the powders [134]. Afterwards, in the calcination process, organic additives are removed, and porosity is reduced. The final agglomerate grain size is usually in tens of micrometres. Kang et al. [100] used spray drying to produce $75 \mathrm{~W}-25 \mathrm{Cu}$ wt. $\%$ nano-composite powder mixture with agglomerates size below $75 \mu \mathrm{m}$ to achieve consistent powder feeding and a homogeneous deposit layer. It should be emphasized that spray drying enables to prepare powder dedicated to the CS process, where agglomerates are needed due to: (i) proper working of conventional powder feeder [135] and (ii) expected higher velocity to overcome bow shock formed above the substrate [100]. To increase the cohesion of agglomerated particles in cermet (e.g., WC-Co), powder sintering is suggested [136,137]. It is worth emphasising, that a major challenge in the nanosized powder mixture preparation is a uniform distribution of the ingredients, especially with a higher specific surface, e.g., carbon nanotubes (CNT) [77]. Bakhsi et al. fabricated aluminium-silicon eutectic alloy powder with an agglomerate particle size of $57 \pm 21 \mu \mathrm{m}$ containing multiwalled CNT, and they used it in atmospheric plasma spraying [99] and HPCS [138] (Figure 11). Nevertheless, to increase deposition efficiency in HPCS, spray dried powder was mixed with pure Al powder.

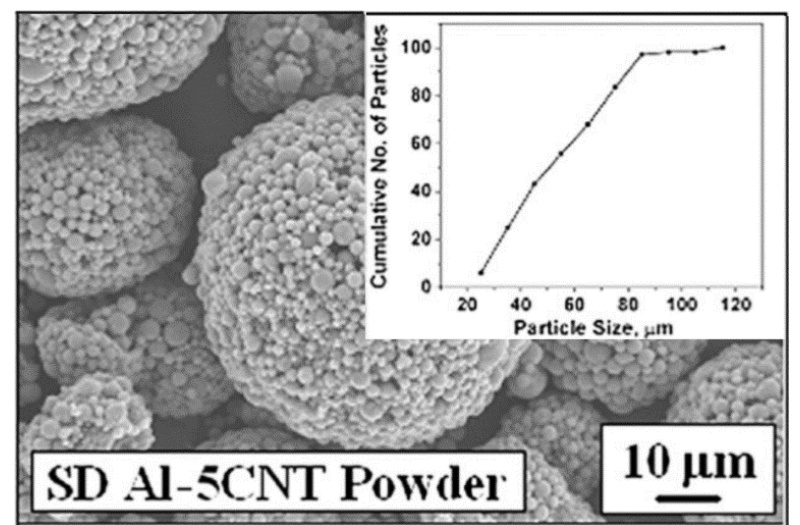

(a)

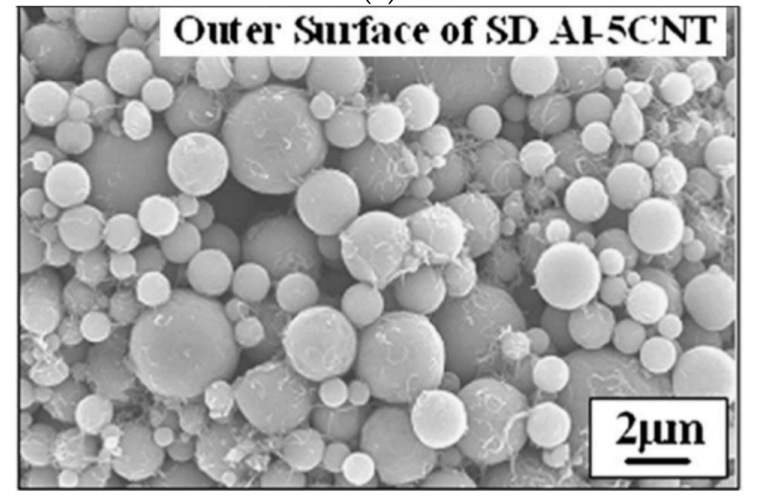

(c)

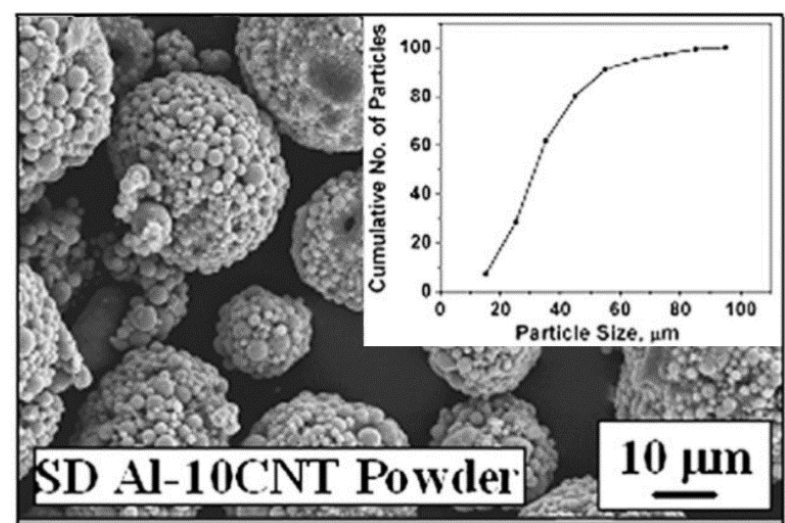

(b)

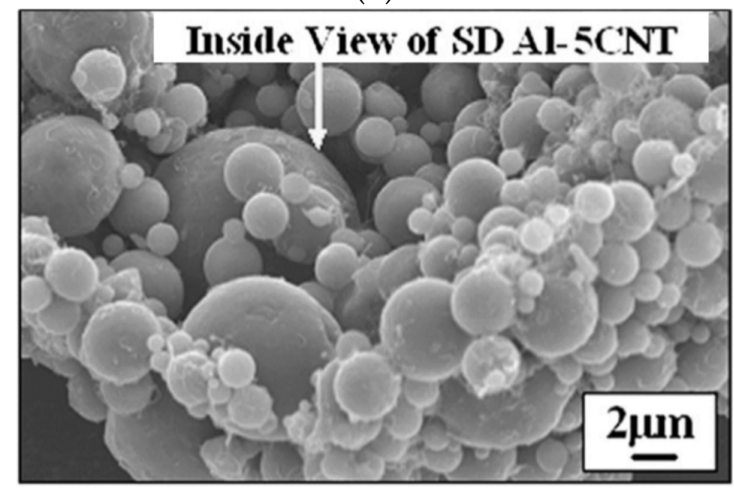

(d)

Figure 11. Cont. 


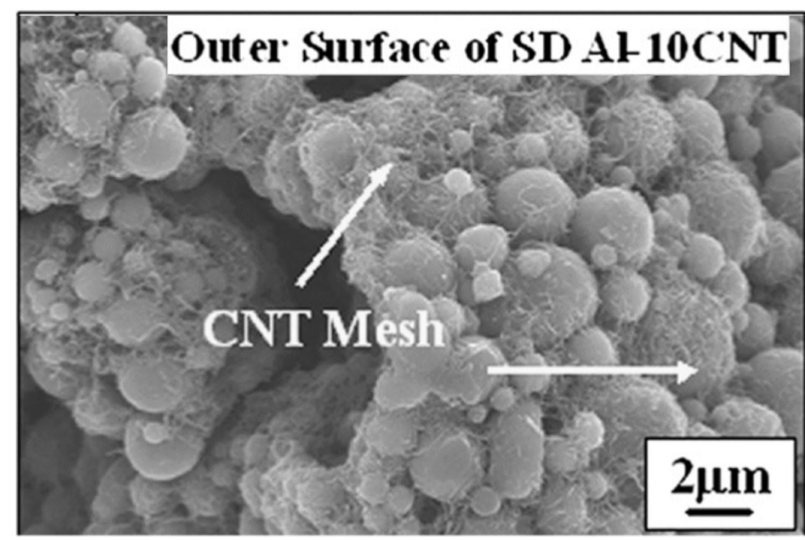

(e)

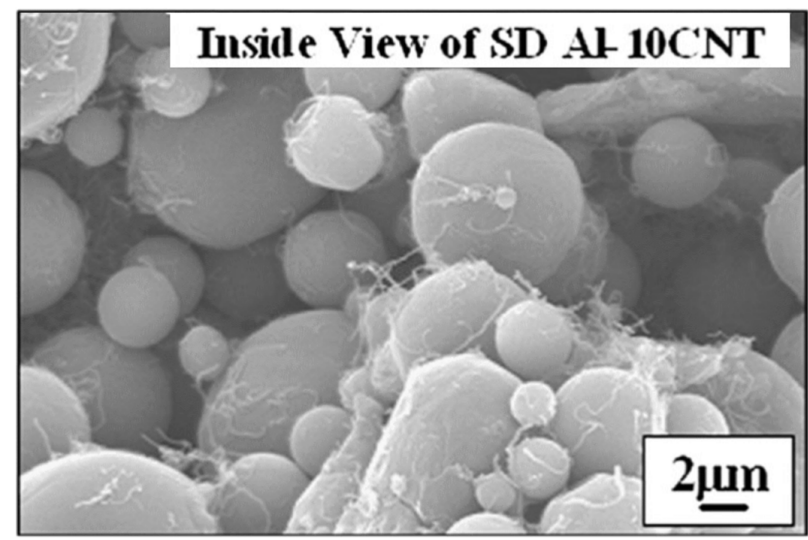

(f)

Figure 11. SEM micrographs of the spray-dried (SD) spherical agglomerates of SD Al-5CNT (a) and SD Al-10CNT powder (b), the outer surface of a single SD Al-5CNT powder (c), inside view of fractured SD Al-5CNT powder (d), the outer surface of a single SD Al-10CNT powder (e), and inside view of fractured SD Al-10CNT powder (f). Inset of (a) and (b) shows the powder size distribution. Reprinted with permission from [138]. Copyright 2009 Elsevier.

\subsection{LPCS PRMMC Coatings Applications}

PRMMC LPCS coatings combine various materials, resulting in advisable properties, e.g., good wear behaviour and increased fatigue strength, a high thermal conductivity combined with an increased creep resistance, great creep and corrosion resistance at high temperatures, as well as coupled high electrical conductivity and mechanical resistance [65].

Despite LPCS limitations, deposition of coatings with low porosity and high adhesion is possible, however, requires highly deformable powder materials and appropriate process parameters. Therefore, in metal -ceramic composites following materials are applied as a matrix: (a) aluminium [48,93,101,122,139-141], (b) copper [62,82,103,142-145], (c) zinc $[81,144]$, (d) tin $[81,105,106]$, or (e) nickel $[63,68,146-149]$. Other metals with higher mechanical properties can be deposited in the form of metal-metal composite, e.g., $\mathrm{Fe} / \mathrm{Al}$ [150], Ti/Al [151], Ni/Zn [152], or by specific powder preparation method, e.g., DLC film by CVD on Ti powder [121]. Nevertheless, some materials are mixed for further intermetallic phase generation in additional PSHT [150,151,153].

The role of hard phase in metal-ceramic composites usually is played by ceramic powders, such as $\mathrm{Al}_{2} \mathrm{O}_{3}[48,101,109,111,112,140]$, $\mathrm{SiC}[82,107,108,113,154], \mathrm{B}_{4} \mathrm{C}[115,146]$, WC $[80,146,147] \mathrm{TiC}[126,146]$. The plastic deformation of impacting metallic particles is responsible for ceramic deposition due to mechanical interlocking in ductile metal. The high content (e.g., $50 \mathrm{wt} . \%)$ of coarse ceramic admixture (e.g., $-30 \mu \mathrm{m}$ ) in initial powder significantly increases the probability of particles collision, fracturing and bouncing off. Consequently, more than $80 \mathrm{vol} . \%$ of the ceramic powder included in the mixtures usually rebounds, decreasing the volume of ceramics in the coating [62]. To increase ceramic content in the coating, the higher mass of ceramic powder should be mixed with metal. Melendez and McDonald [63] obtained 52 vol.\% of WC particles in WC + Ni coating deposited with the use of $96 \mathrm{wt} . \% \mathrm{WC}+4 \mathrm{wt} . \% \mathrm{Ni}$ powder blend mixture. The powder preparation method is meaningful as well. Feng et al. [115] mechanically blended Ni with $\mathrm{B}_{4} \mathrm{C}$ in various proportions. However, the ceramic content was always less than 20 vol.\%. By powder cladding with the use of the CVD method, Feng et al. obtained a much higher deposition efficiency of $\mathrm{B}_{4} \mathrm{C}$ particles in the cold spray coatings. Ceramic content in the coating reached 44.0 vol. $\%$ for the $\mathrm{Ni}_{\mathrm{CVD}}-87$ vol. $\% \mathrm{~B}_{4} \mathrm{C}$ powder mixture. In one of my research [68], I coated $\mathrm{Al}_{2} \mathrm{O}_{3}$ with $\mathrm{Ni}$ to increase alumina content in the coating and to avoid the fracture of ceramic particles. As a result, the ceramic contribution in the coating sprayed with mechanically blended commercial $\mathrm{Ni}-\mathrm{Al}_{2} \mathrm{O}_{3}$ and $\mathrm{Ni}$ coated $\mathrm{Al}_{2} \mathrm{O}_{3}$ increased from $7.3 \%$ to $30.5 \%$. Nevertheless, ceramic content in the coating should be optimized to achieve expected properties. Zhang et al. [140] sprayed pure Al2024 
and $\mathrm{Al} 2024-\mathrm{Al}_{2} \mathrm{O}_{3}$ composite coatings on 2024-T3 aluminium alloy substrate and noticed that the addition of $20 \mathrm{wt} . \% \mathrm{Al}_{2} \mathrm{O}_{3}$ significantly increased the residual compressive stress (48.3 MPa) (Figure $12 \mathrm{a})$ and adhesion strength $(\sim 50.68 \mathrm{MPa})$ and decreased porosity $(0.55 \%)$ (Figure $12 \mathrm{~b})$ and surface roughness $(11.82 \mu \mathrm{m})$ due to the tamping effect of metal powder by ceramics. However, increasing the ceramic content in the powder to $40 \mathrm{wt} . \%$ and $60 \mathrm{wt} . \%$ resulted in an increased presence of fractured $\mathrm{Al}_{2} \mathrm{O}_{3}$ particles inside the composite coating. As a result, enhancement of the material was limited.

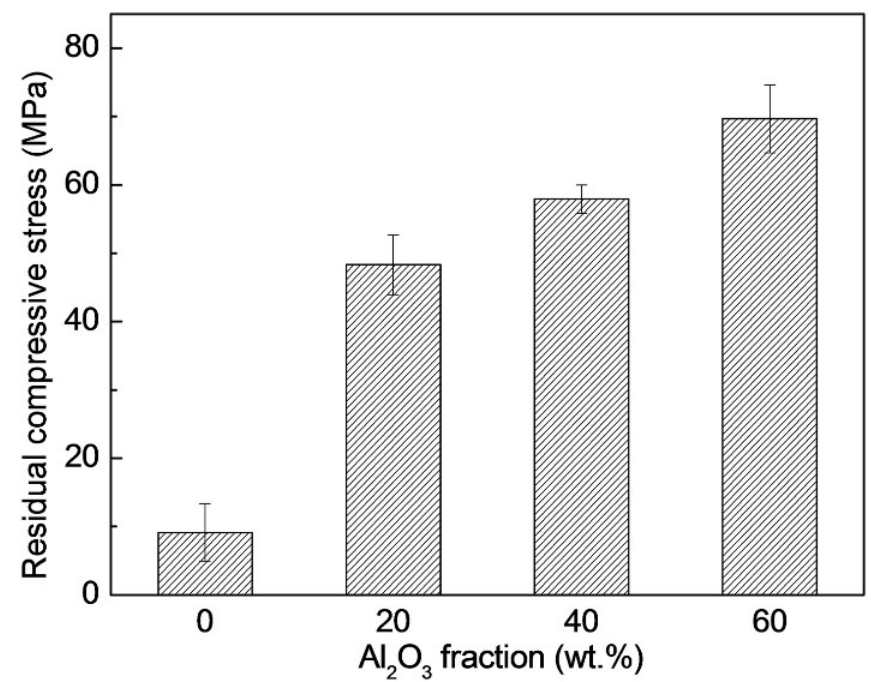

(a)

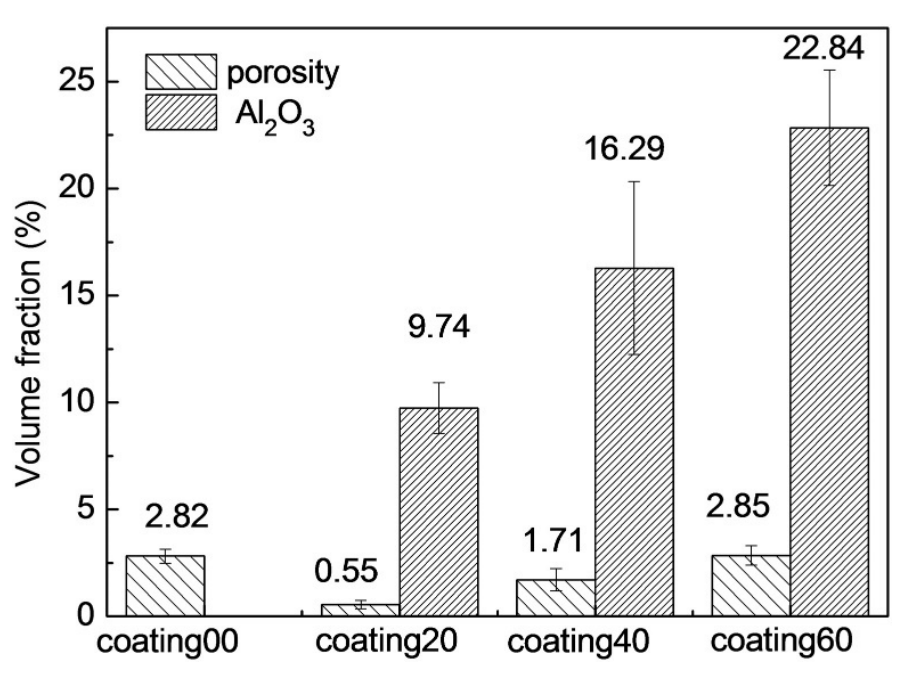

(b)

Figure 12. Residual compressive stress variations with different $\mathrm{Al}_{2} \mathrm{O}_{3}$ weight fractions (wt.\%) on the surface layer (a), porosity and $\mathrm{Al}_{2} \mathrm{O}_{3}$ volume fraction (b) of the coatings. Reprinted with permission from [140]. Copyright 2019 Elsevier.

The conditions of LPCS make the process attractive for many applications. Previously, as a portable unit with a handy spraying gun, it was employed first of all for structural, dimensional, or functional restoration, and since the nozzle exit diameter is $5 \mathrm{~mm}$, the work is precise without any additional masking. A good coating's machinability ensures high surface quality with the possibility of on-site repair [64]. What is more, the method can be adapted to the recycling process and elongating selected products' life cycle. In the field of art, LPCS can be applied as decoration of various panel natures including glass, rusty sheets of iron, copper plates. Different metal-ceramic feedstock powders are explored as paintwork due to possible metal colour mixing and surface topography modifications. Further applications of LPCS depend on the expected functionality and include mostly coatings with high electrical conductivity $[103,145]$, electrochemical corrosion resistance $[62,83,102,105]$, high-temperature corrosion resistance [155,156], wear resistance $[79,157,158]$, solid lubrication $[121,159]$, interlayers in welding or soldering processes $[160,161]$, etc. The high quality of the coating and its properties arise from ceramic addition, which significantly reduces the porosity and increases the contact surface area of metal particles [122,162].

LPCS ensures uniform distribution of ingredients in dense PRMMC composite coatings and as a result high electrical conductivity and corrosion resistance. According to my previous research [62], ceramic admixture increases the surface contact between copper particles due to plastic deformation and as a result electrical conductivity up to $62.5 \%$ IACS. A further increase in electrical conductivity is possible due to the PSHT of the coating (Figure 13a) [62,145]. It should be noted that dense $\mathrm{Cu}-\mathrm{Al}_{2} \mathrm{O}_{3}$ coatings with low porosity exhibit high electrical conductivity (about $90 \%$ of initial value) after salt-spray and Kesternich corrosion tests [82]. Moreover, copper-alumina composite coatings can significantly increase the corrosion potential of aluminium busbars due to the reduction of porosity and densification of the coating [62] (Figure 13b). Dzhurinsky et al. [163] examined 
aluminium, aluminium-alumina and aluminium-zinc-alumina coatings and demonstrated by accelerated corrosion test that corrosion of the sprayed composites intensified as the concentration of alumina particles increased within the coating. Wang et al. [162] tested by HPCS deposition of Al 5056-SiC mixture and concluded that SiC particles crack due to high-velocity impact and provide passage for electrolyte through inter-particle boundaries intensifying corrosion progress. On the other hand, Bai et al. [104] showed that the presence of $\mathrm{Zn}$ elements played a role in sacrificial anodic protection in $\mathrm{Zn}-\mathrm{Ni}$ composite coatings and ensured higher corrosion resistance compared to pure zinc coatings. Therefore, the composite mixture should be matched to the designed application.

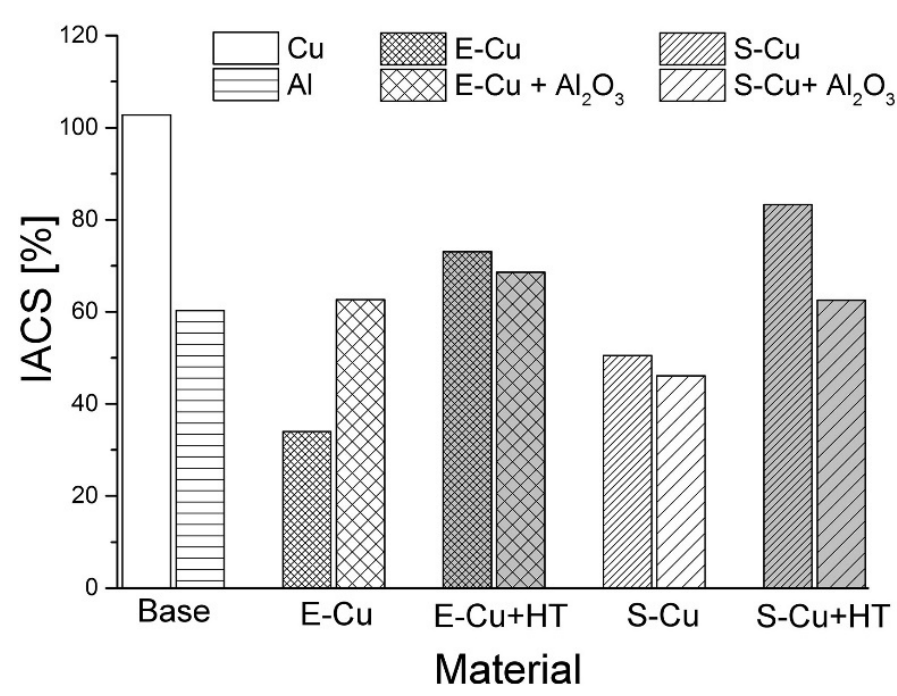

(a)

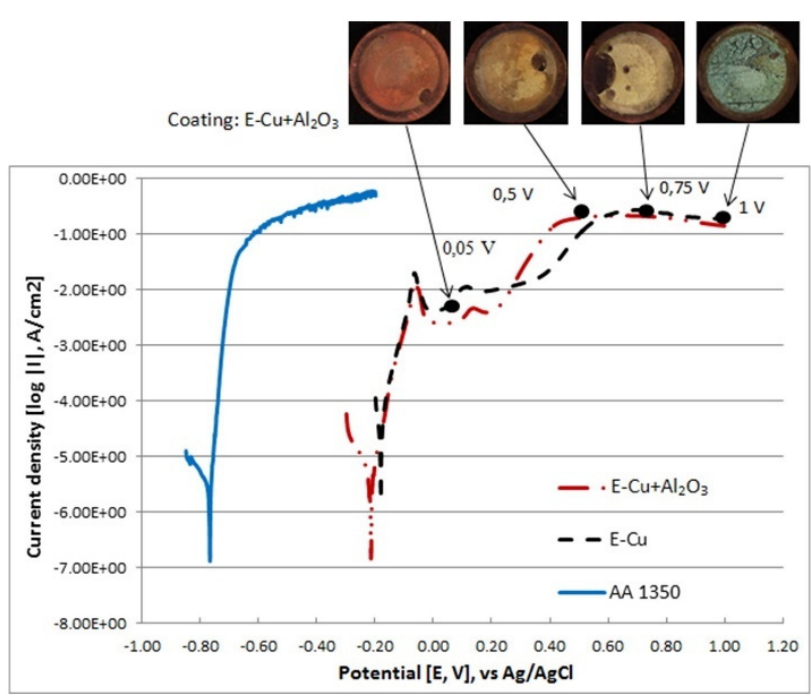

(b)

Figure 13. Electrical conductivity (a) and polarization behaviour (b) of LPCS coatings on AA1350 substrate. Powder designation: E-dendritic, S-spherical, HT-heat treatment of the coating. Reprinted with permission from [62]. Copyright 2017 Elsevier.

High-temperature corrosion-resistant coatings by CS are usually sprayed with the use of HPCS units [164-166]. The commonly applied powder material is Ni-based superalloy with chromium admixture, which has to block the penetration of corrosive species toward the substrate. Kilicay [156] applied $\mathrm{Ni}-\mathrm{Zn}-\mathrm{Al}_{2} \mathrm{O}_{3}$ to spray MMC coating on TZM alloy by LPCS. Kilicay chose $\mathrm{Ni}$ and $\mathrm{Zn}$, which are very prone to oxidation and formed $\mathrm{NiO}$ and $\mathrm{ZnO}$ films on the coating surface. As a result, coating prevented contact of oxygen to the titanium-zirconium-molybdenum (TZM) alloy by the reaction of Ni and Zn with oxygen at high temperatures of $900{ }^{\circ} \mathrm{C}$. The $\mathrm{Al}_{2} \mathrm{O}_{3}$ was chosen to densify the coating and improve coating adhesion. The specific mass changes of the TZM substrate and MMC coating at high temperature and air atmosphere is shown in Figure 14a. The mass of the TZM alloy sharply decreased by forming $\mathrm{MoO}_{3}$ oxide layers at temperatures above $600{ }^{\circ} \mathrm{C}$ due to the evaporation mechanism. The results showed that the Ni-Zn- $\mathrm{Al}_{2} \mathrm{O}_{3} \mathrm{MMC}$ coating exhibited a remarkable oxidation resistance on the TZM alloy at the test temperatures. It is thus an interesting alternative for hot corrosion resistant superalloys coating, which was shown, e.g., by Zhang et al. [165] for CoNiCrAlY deposited with LPCS. 


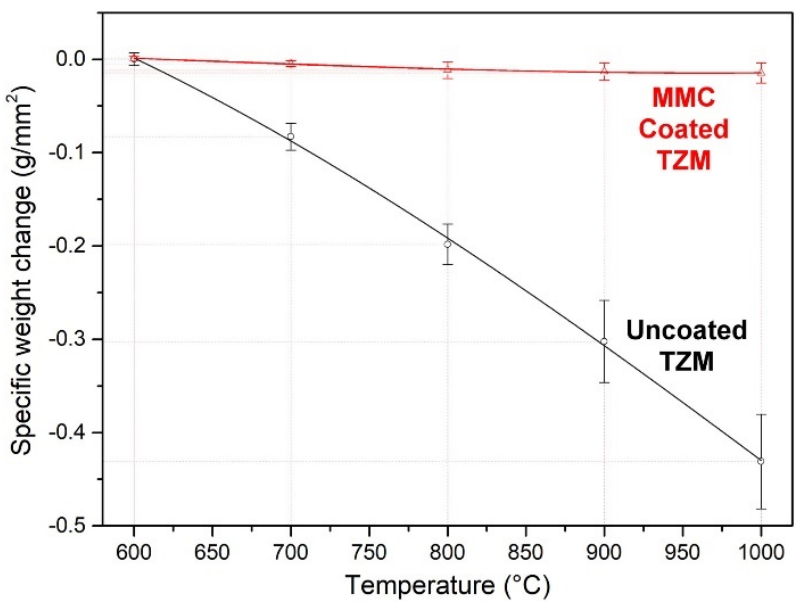

(a)

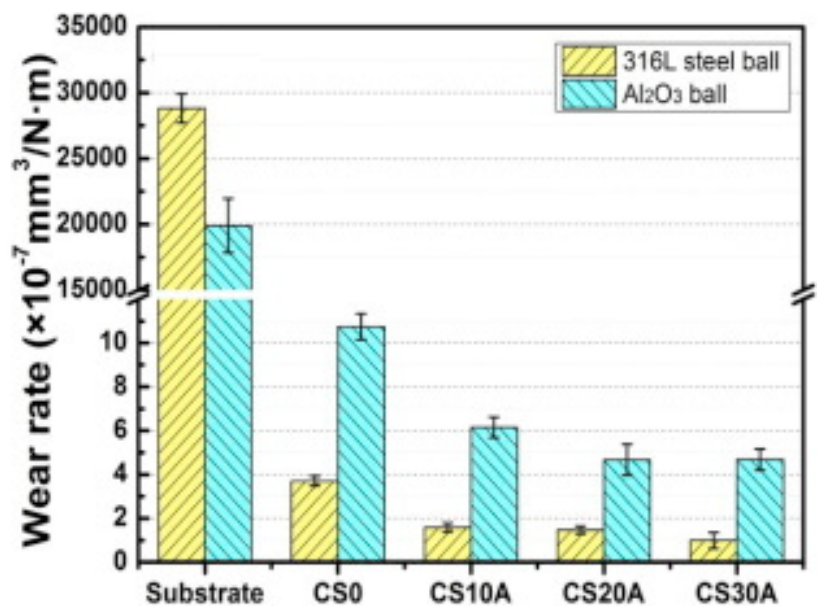

(b)

Figure 14. The specific mass changes of the TZM substrate and $\mathrm{Ni}-\mathrm{Zn}-\mathrm{Al}_{2} \mathrm{O}_{3}$ coating after high-temperature oxidation tests (a) (Reprinted with permission from [156]. Copyright 2020 Elsevier.) and wear rate in artificial seawater of $\mathrm{CuSn}_{5}+\mathrm{Al}_{2} \mathrm{O}_{3}$ $(0,10,20,30 \mathrm{wt} \%)$ coatings and aluminium alloy 7075-T651 substrate (b) (Reprinted with permission from [143]. Copyright 2012 Elsevier).

The wear resistance of the coating is highly influenced by MMC composition. The most popular LPCS process mixtures $\left(\mathrm{Al} / \mathrm{Al}_{2} \mathrm{O}_{3}\right.$ and $\left.\mathrm{Cu} / \mathrm{Al}_{2} \mathrm{O}_{3}\right)$ presents a relatively high coefficient of friction (COF) of 0.764 [84] and 0.88 [102], respectively. An optimization of spraying process parameters can decrease the COF value. For instance, Szala et al. [84] reported the COF of 0.555 . What is more, Szala et al. obtained in the wear tests a superior slide wear resistance of $\mathrm{Cu} / \mathrm{Al}_{2} \mathrm{O}_{3}$ coating $\mathrm{K}=7.41 \times 10^{-7} \mathrm{~mm}^{3} \cdot \mathrm{N}^{-1} \cdot \mathrm{m}^{-1}$. Wear resistance should be regulated by the content of the ceramic powder admixture. Chen et al. [143] examined the $\mathrm{CuSn} 5-\mathrm{Al}_{2} \mathrm{O}_{3}$ mixture and noticed that the wear rate of coatings decreases with the increase of $\mathrm{Al}_{2} \mathrm{O}_{3}$ content (up to $30 \mathrm{wt} . \%$ ) and obtained very satisfactory results (see Figure 14b). Lee et al. [146] sprayed Ni mechanically blended with $\mathrm{B}_{4} \mathrm{C}, \mathrm{TiC}$ and WC and analysed the effect of carbide particle momentum on coatings wear resistance. By the applied mathematical model Lee et al. showed that the momentum of WC particles was significantly higher compared to the other ceramic powder particles. Consequently, WC particles increased the level of work hardening of the nickel matrix. What is more, due to the higher fracture toughness of large WC (size of $36 \pm 11 \mu \mathrm{m}$ ) particles and increased work hardening of $\mathrm{Ni}$, the WC-Ni MMC coatings showed the lowest wear resistance. The proportion of metal-ceramic powders in PRMMC has a significant influence on the wear resistance of the coating. This statement was proven by Melendez et al. [147] who blended nickel with various contents of WC and showed that the wear rate of the coatings decreased significantly as the mean free path between the agglomerated WC particles decreased. The highest wear resistance, comparable to high-velocity oxygen fuel (HVOF) and HPCS WC-based coatings, Melendez et al. obtained for WC-Ni (96-4 wt.\%) powder mixture, resulting in a 66-44 wt.\% coating (Figure 15a). Furthermore, high ceramic content in PRMMC can promote other applications, such as steam reforming, which requires a catalyst with support. A popular couple would be nickel catalysts with alumina as support. The activity of the nickel-based catalyst is affected by the reduction degree of nickel species [167], while the alumina support is affected by a high specific surface area, providing a high dispersion of the metallic phase [168]. To assure high ceramic content, I sprayed by LPCS nickel-cladded alumina powder and obtained the coating with $\mathrm{Al}_{2} \mathrm{O}_{3}$ up to $30.5 \mathrm{wt} \%$ [68]. 


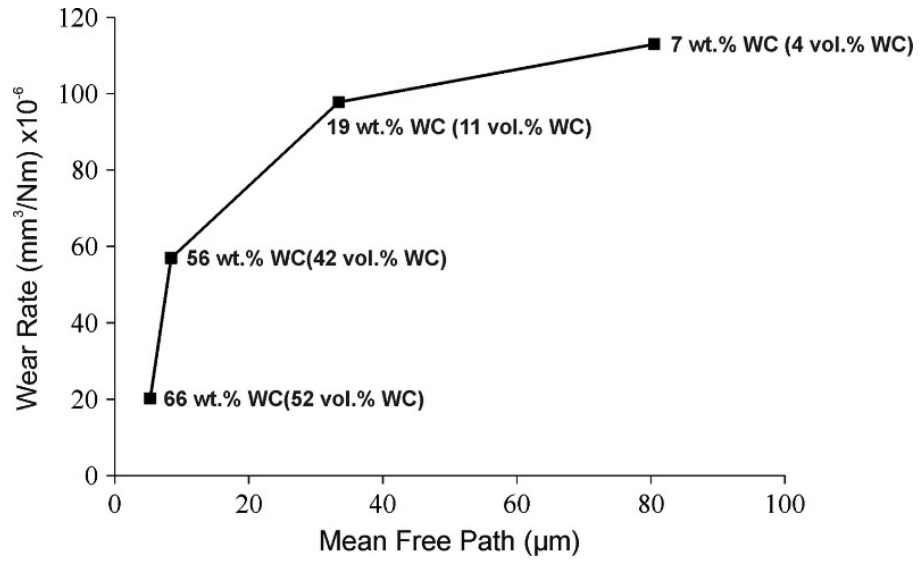

(a)

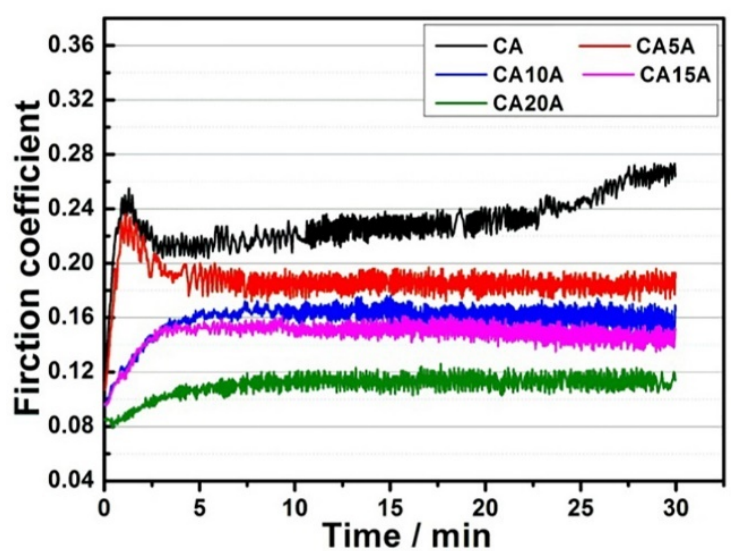

(b)

Figure 15. Curve of wear rate versus mean free path for various WC-Ni composite coatings (a) (Reprinted with permission from [147]. Copyright 2013 Elsevier.) and COF curves of (Cu-5Sn)/ $\mathrm{Al}_{2} \mathrm{O}_{3}-\mathrm{Ag}$ coatings with various $\mathrm{Ag}$ content (0-20 wt.\%) (b) (Reprinted with permission from [142]. Copyright 2020 Elsevier).

A great opportunity to decrease the COF gives the application of solid-lubricating coating. The most popular material is a mixture of metal $[159,169]$ or metal-ceramic [170] powders with graphite powder. Okimura et al. [121] coated $\mathrm{Cu}$ spherical particles with diamond-like carbon (DLC) by CVD method for further usage in the LPCS process and concluded that the Cu-DLC composite coatings deposited from thin DLC-coated Cu particles behaved like a solid lubricant in the ball-on-disk tests. For the protection of moving parts in seawater conditions, Chen et al. [142] applied to silver in the metal-ceramic mixture and sprayed (Cu-5Sn) $/ \mathrm{Al}_{2} \mathrm{O}_{3}$-Ag solid-lubricating LPCS MMC coating. Silver, similar to graphite, presents low friction and wear in artificial seawater environments. Via the controlled addition of silver powder, up to $20 \mathrm{wt} . \% \mathrm{Ag}$, the COF of the coatings was significantly decreased (Figure 15b).

The LPCS can also solve the difficulties of joining materials with low weldability. Due to significant differences in physical and chemical properties, such as melting and boiling temperature, coefficient of thermal and electrical conductivity, an oxide layer, the limited mutual solubility resulting in heterogeneous solutions at room temperature, thermal expansion mismatch, and suitability at higher temperatures, dissimilar materials show low bond strength [171-173]. As a result, the formation of bulky and directional intermetallic compounds detrimental to the joint occurs [173-175]. Among various joined construction materials, aluminium and steel are very popular. However, the resistance spot welding (RSW) joint of these metals is characterised by reduced mechanical properties resulting from the brittle intermetallic phases $[176,177]$. To prevent the formation of the hard phases, a smooth transition zone between two different metals by an intermediate layer can be obtained [177-181]. Nevertheless, most of the applied methods are based on large-area coating. LPCS enables coating a precise area of the material before welding. Analysing the material for the aluminium-steel intermediate layer I proposed free materials: $\mathrm{Al}^{-} \mathrm{Al}_{2} \mathrm{O}_{3}$, $\mathrm{Ni}-\mathrm{Al}_{2} \mathrm{O}_{3}$ and $\mathrm{Al}-\mathrm{Ni}-\mathrm{Al}_{2} \mathrm{O}_{3}$ to analyse the formation of advisable Al-Ni intermetallic phases inside the coating [160]. Nevertheless, $\mathrm{Ni}-\mathrm{Al}_{2} \mathrm{O}_{3}$ interlayer showed after welding the most uniform microstructure and as a result, the highest shear strength comparable with the aluminium + aluminium joints (Table 2). Furthermore, the fracture out of the welding nugget zone indicated a higher strength of joint than the aluminium base material. Wojdat et al. [161] applied multi-layered coatings as an interlayer in the soldering process of aluminium alloy to graphite. The graphite was coated by soft aluminium, then densified by $\mathrm{Al}-\mathrm{Al}_{2} \mathrm{O}_{3}$, to be finally sprayed by copper coating. The aluminium alloy was coated by copper as well and soldered by tin to multi-layered graphite. The metallic (e.g., $\mathrm{Al}$ and $\mathrm{Cu}$ ) and PRMMC (e.g., $\mathrm{Al}-\mathrm{Al}_{2} \mathrm{O}_{3}$ and $\mathrm{Cu}-\mathrm{Al}_{2} \mathrm{O}_{3}$ ) composites, LPCS interlayers effectively 
limits formation of the reaction zones in soldering process and improves the mechanical properties of the joint [182]. It is worth emphasising that pure metal coatings are better intermediate layers in the soldering process [182-185]. Nevertheless, ceramic particles present on the LPCS coating surface limit soldering properties, such as the wettability of the composite interlayer with $\mathrm{Zn}-\mathrm{Al}$ solder, which eliminates the use of $\mathrm{Al}^{-} \mathrm{Al}_{2} \mathrm{O}_{3}$ powder in the soldering process [183].

Table 2. Results of steel-aluminium tensile shear force measurements of RSW joints [160].

\begin{tabular}{ccccc}
\hline Scheme & Interlayer & $\begin{array}{c}\text { Coating } \\
\text { Thickness }[\mu \mathrm{m}]\end{array}$ & $\begin{array}{c}\text { Shearing Force } \\
{[\mathbf{N}]}\end{array}$ & Fracture \\
\cline { 1 - 4 } 1.1 & $\mathrm{Al}+\mathrm{Al}_{2} \mathrm{O}_{3}$ & 250 & 1080 & Cohesive \\
\cline { 3 - 5 } 1.2 & & 500 & 625 & $\begin{array}{c}\text { Adhesive, } \\
\text { cohesive }\end{array}$ \\
\cline { 3 - 5 } 2.1 & $\mathrm{Al}+\mathrm{Ni}+\mathrm{Al}_{2} \mathrm{O}_{3}$ & 250 & 2400 & Adhesive \\
\cline { 3 - 5 } 2.2 & \multirow{2}{*}{$\mathrm{Ni}+\mathrm{Al}_{2} \mathrm{O}_{3}$} & 500 & 2500 & Adhesive \\
\cline { 3 - 5 } 3.1 & & 250 & 3060 & Base material \\
\cline { 3 - 5 } 3.2 & & 500 & 2850 & Base material \\
\hline
\end{tabular}

The LPCS can be combined with a magnetron sputtering (MS) process to produce transparent and conductive thin films. The MS can be used to deposit a variety of materials. Nevertheless, some ceramic coatings (e.g., indium-tin-oxide (ITO)) requires ceramic or metallic feedstock, called target. The ceramic $\mathrm{In}_{2} \mathrm{O}_{3}-\mathrm{SnO}_{2}$ sinter provides higher performance and thus is more frequently applied than metallic In-Sn. Nevertheless, the sinters are soldered to the copper carrier disk and show a tendency to wrap or crack due to differences in thermal expansion coefficient $[186,187]$. To solve this problem, I produced a composite Sn- $\mathrm{In}_{2} \mathrm{O}_{3}$ target by LPCS coating $[117,118]$. Due to the oxidation of Sn before spraying, an additional SnO phase was obtained in the coating. Deposited LPCS coatings showed mean thickens of $1 \mathrm{~mm}$ with uniform distribution of indium oxide and tin particles. Finally, high-quality ITO transparent thin films on glass substrate were obtained in the MS process, with the highest transmission of $88 \%$ at $\lambda=550 \mathrm{~nm}$ and the lowest resistivity of $0.03 \Omega \cdot \mathrm{cm}$.

Functional graded PRMMCs coatings can be sprayed by LPCS as well. As shown in one of my previous papers [103], the $3 \mathrm{~mm}$ thick $\mathrm{Al}-\mathrm{Al}_{2} \mathrm{O}_{3}$ coating on steel substrate had microhardness variations through the thickness from $83.7 \mathrm{HV} 0.3$ next to the substrate up to $129.5 \mathrm{HV} 0.3$ in the top part (Figure 16). It arose from the thermal recovery of the aluminium in the lower part of the composite coating as multi-layered spraying of thick coating. In this way, the coating gained high hardness on the surface while being ductile at the coating/substrate interface. Adebiyi et al. [154] sprayed a mixture of Ti-6Al-4V with $\mathrm{SiC}$ powder by LPCS process. Deposited coatings were free of phase transformations, decarburization, or decompositions. The high impact of the blend resulted in microstraining, amorphization, and grain refinement. The hardness was improved from $291 \pm 13.9$ HV0.3 in the substrate to $652 \pm 12.7$ HV0.3 in the coating due to the partially homogeneous distribution of $\mathrm{SiC}$. What is more, the hardness and other mechanical properties can be increased by using nanostructured coatings, deposited by nano-sized powders [188]. 


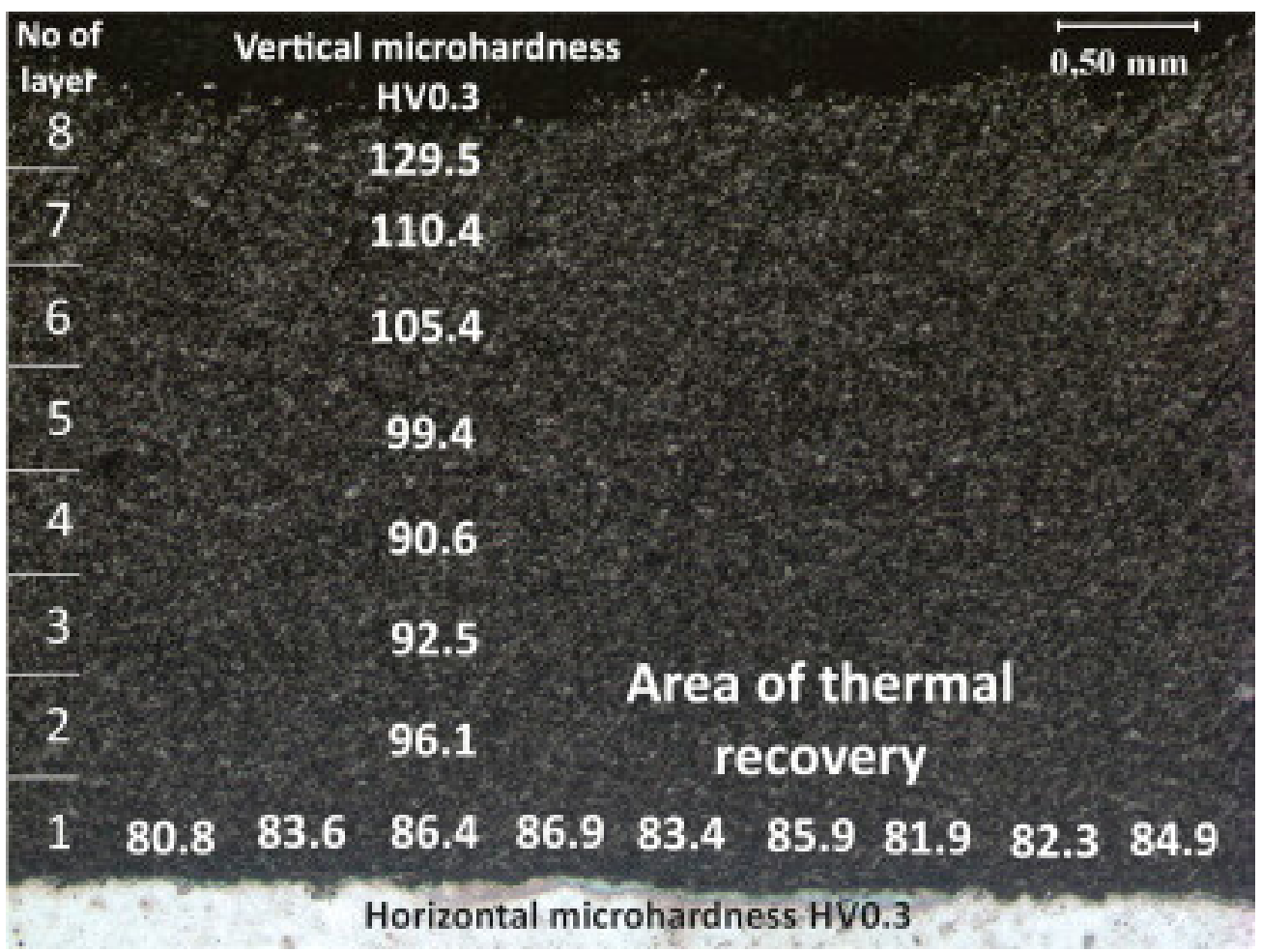

Figure 16. Microhardness distribution in $3 \mathrm{~mm}$ thick $\mathrm{Al}-\mathrm{Al}_{2} \mathrm{O}_{3}$ composite LPCS coating. Reprinted with permission from [101]. Copyright 2016 Elsevier.

The LPCS can be coupled with laser [65,189-192] or friction stir processing (FSP) [193-197] treatment to improve structure of as-sprayed coating. In a laser-assisted low-pressure cold spraying (LALPCS) process the cold spray spot interacts with the laser irradiation on the substrate and as a result, local temperature rises (Figure 17). Kulmala et al. [65] used LALPCS to spray copper-alumina and nickel-alumina coatings and found that laser irradiation increased deposition efficiency and densification of the coatings. Moreover, copper-alumina coating open cell potential was near bulk potential (Figure 18a). Another surface modification technique, friction stir processing (FPS), shows great capability in improving materials structures, quality, and preparing the surface of metal-matrix composites [195-197] (Figure 19). Hodder et al. [198] applied friction stir processing to modify as-sprayed LPCS Al- $\mathrm{Al}_{2} \mathrm{O}_{3}$ and found that the particle mean free path decreased significantly due to the re-distribution of the $\mathrm{Al}_{2} \mathrm{O}_{3}$ particles trapped within the $\mathrm{Al}$ matrix, and consequently increased load share and microhardness values. Khodabakhshi et al. [199] fabricated a dense titanium coating with refined grain structure by combining cold spraying and FSP. The optimization of the plunge depth of the FSP head resulted in compressive residual stresses with a maximum negative value of around $400 \mathrm{MPa}$ at the advancing side. What is more, Khodabakhshi et al. concluded in another research [200] that the bonding mechanism between aluminium substrate and titanium particles in CS was reinforced by a chemical bonding. Due to material mixing and deformation, the solid-state chemical inter-diffusion of elements occurred during FSP (Figure 18b). Consequently, the $\mathrm{Al}_{3} \mathrm{Ti}$ intermetallic layer with a thickness of $\sim 10-20 \mathrm{~nm}$ formed inducing nano-scale interfacial chemical bonding. The formation of intermetallic phases that increase hardness of the coating is possible by conventional PSHT of the coating in the furnace. In this case two reactive metal powders (e.g., $\mathrm{Al}$ and $\mathrm{Ni}$ ) should be mechanically blended and LPCS sprayed. Nevertheless, high porosity forms in the coating. To eliminate the porosity, I proposed resistance spot welder (RSW) heat treatment with simultaneous compression of the electrodes [153]. As a result, the porosity of the coating decreased from $20.8 \%$ to $4.6 \%$ in conventionally and RSW heat-treated coatings, respectively. 
Table 3 shows the main applications of PRMMC coatings produced by LPCS.

Table 3. Selected applications of the LPCS PRMMC coatings.

\begin{tabular}{|c|c|c|c|}
\hline Powder Material & Powder Preparation Method & Coating Application & Reference \\
\hline $\mathrm{Al}_{2} \mathrm{O}_{3}-\mathrm{Cu}$ & Mechanically blended & $\begin{array}{l}\text { Corrosion protection, electrical } \\
\text { conductivity, wear resistance }\end{array}$ & {$[62,82,84,103,145]$} \\
\hline $\mathrm{Al}_{2} \mathrm{O}_{3}-\mathrm{Al}$ & Mechanically blended & $\begin{array}{c}\text { Corrosion protection, wear resistance, } \\
\text { intermediate layer for dissimilar } \\
\text { materials joining }\end{array}$ & {$[83,84,101,161,163]$} \\
\hline WC-Ni & Mechanically blended & Wear resistance & {$[63,147]$} \\
\hline $\begin{array}{l}\mathrm{Al}_{2} \mathrm{O}_{3}-\mathrm{Ni} \text { and } \\
\mathrm{Al}_{2} \mathrm{O}_{3}-\mathrm{Ni}-\mathrm{Zn}\end{array}$ & $\begin{array}{l}\text { Metal cladded ceramics or } \\
\text { mechanically blended }\end{array}$ & $\begin{array}{l}\text { High temperature corrosion resistance, } \\
\text { steam reforming, intermediate layer for } \\
\text { dissimilar materials joining }\end{array}$ & {$[68,104,156,160]$} \\
\hline $\begin{array}{l}\mathrm{Al}_{2} \mathrm{O}_{3}-\mathrm{Cu} \text {-graphite } \\
\quad \text { and } \\
\mathrm{Al}_{2} \mathrm{O}_{3}-(\mathrm{Cu}-5 \mathrm{Sn})-\mathrm{Ag}\end{array}$ & Mechanically blended & Solid-lubricating coatings & {$[142,170]$} \\
\hline $\mathrm{In}_{2} \mathrm{O}_{3}-\mathrm{Sn}$ & Satellited & Targets for magnetron sputtering & {$[117,118]$} \\
\hline
\end{tabular}

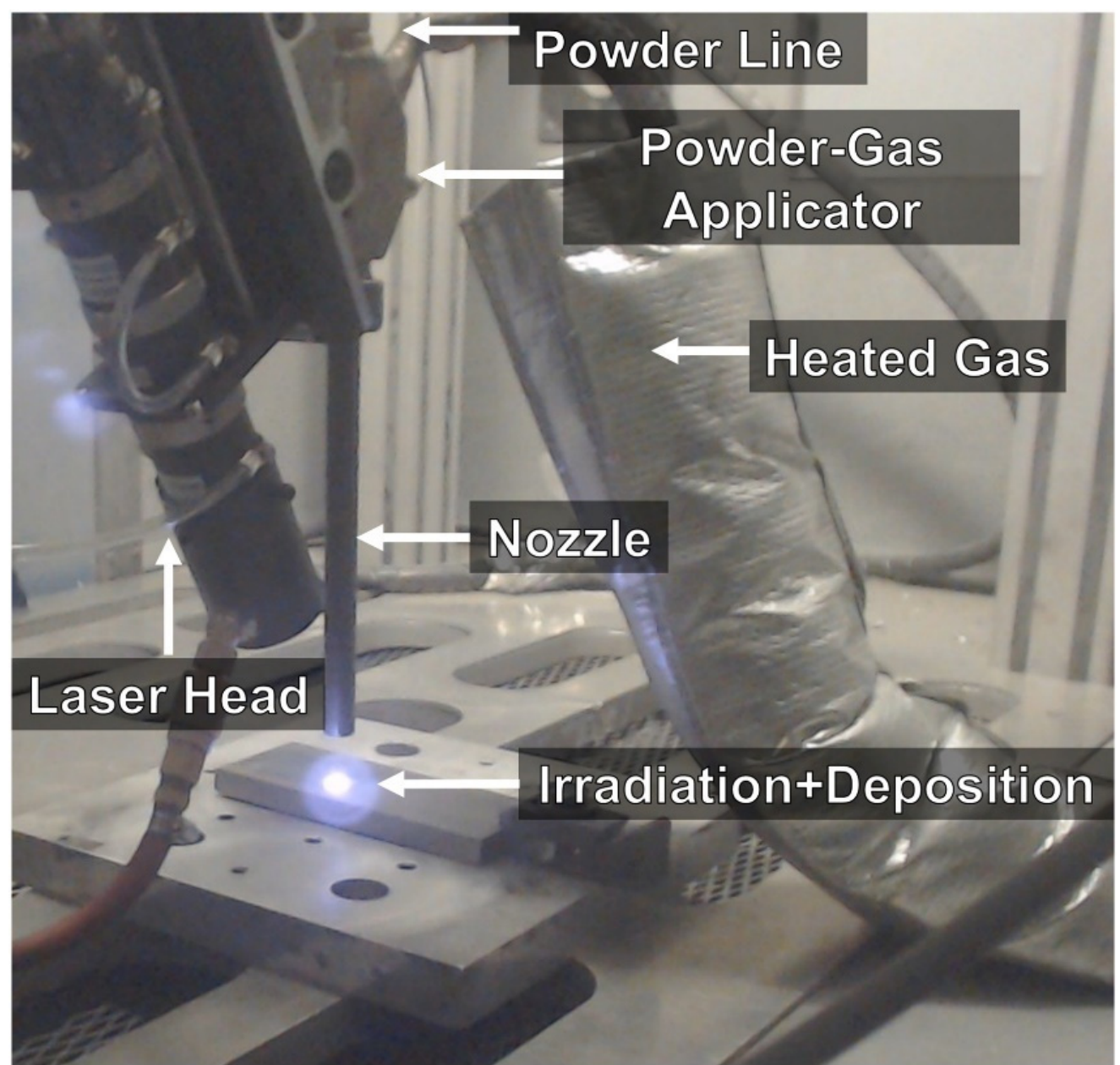

Figure 17. Overview of the LACS process. Reprinted with permission from [190]. Copyright 2020 Elsevier. 


\begin{tabular}{|c|c|c|}
\hline- LALPCS Cu $800^{\circ} \mathrm{C}$ & LALPCS Cu $650^{\circ} \mathrm{C}$ & ---- Cu bulk \\
\hline- LALPCS $\mathrm{Cu}$ & $\begin{array}{l}- \text { LPCS Cu } \\
\ldots \ldots \cdot \text { HVOF } \mathrm{Cu}\end{array}$ & -.... Fe52 \\
\hline
\end{tabular}

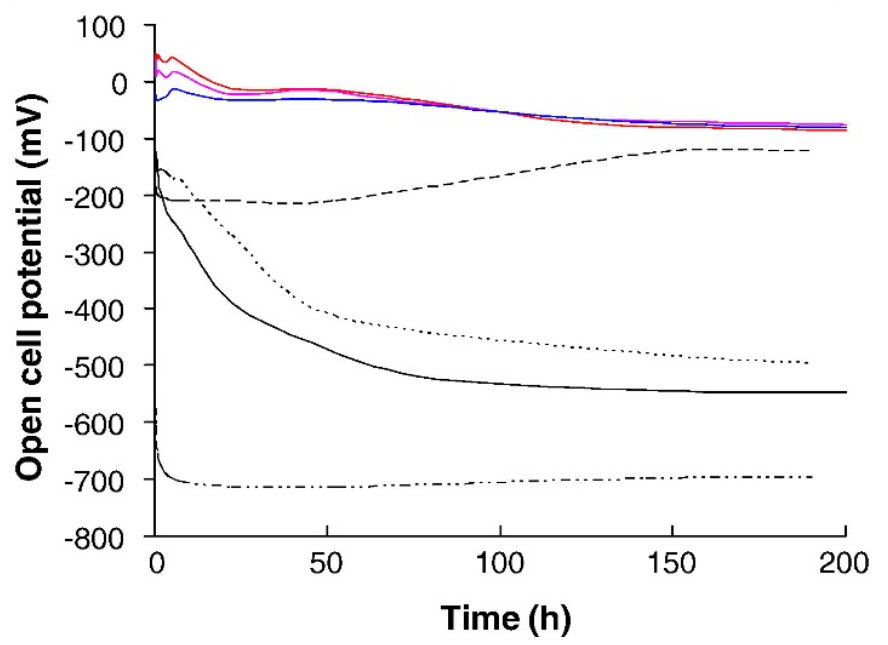

(a)

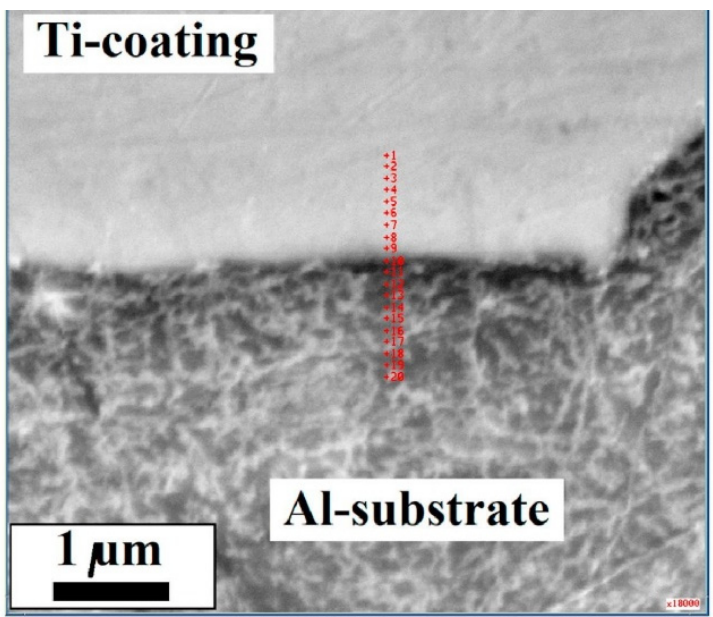

(b)

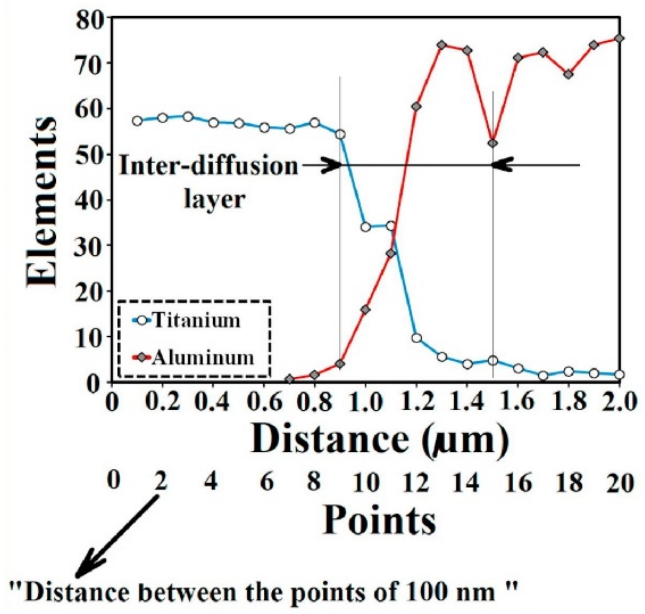

(c)

Figure 18. Open-cell potential versus time for the LALPCS and LPCS Cu+ $\mathrm{Al}_{2} \mathrm{O}_{3}$ coatings and as references were $\mathrm{HVOF}$ sprayed Cu coating, bulk Cu and substrate material Fe 52 (a) (Reprinted with permission from [65]. Copyright 2008 Elsevier.) the SEM image from Al-Ti interface showing the indexing points for Auger analysis (b) and Auger electron spectroscopy line-scan analysis results from the interaction zone at the interface (c) (Reprinted with permission from [200]. Copyright 2018 Elsevier). 


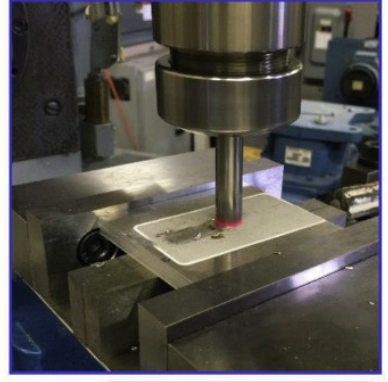

(a) $\begin{aligned} & \text { Friction-stir modification } \\ & \text { of cold-sprayed coating }\end{aligned}$

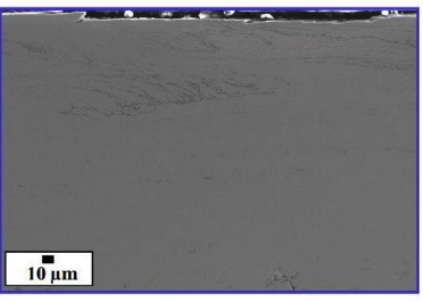

(d)

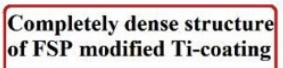

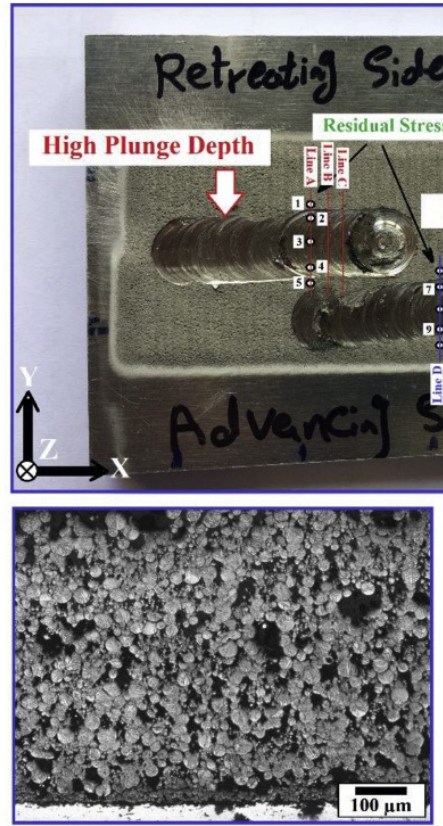

(e)

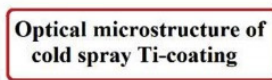

Figure 19. Schematic implementation of FSP on the surface of CS titanium coating (a), top-view macro-image from the prepared coating layers after two-steps cold gas spraying and friction-stirring showing the measurement profiles for residual stress (b), FE-SEM images $(\mathbf{c}, \mathbf{d})$ and optical microstructures $(\mathbf{e}, \mathbf{f})$ from the porous CS sprayed titanium $(\mathbf{d}, \mathbf{f})$ coating and $(\mathbf{d}, \mathbf{f})$ friction-stirred one, respectively, indentation Vickers micro-hardness profile close to the surface of produced modified coating layer (g). Reprinted with permission from [199]. Copyright 2019 Elsevier.

\section{LPCS All-Ceramic Coatings}

Ceramic materials are characterized by more complex structures than metals. The ionic and covalent bonding assures high strength and hardness, low thermal conductivity, or chemical inertness characteristics [201], and thus these are common and versatile types of coating applied in thermal spraying processes. Various compositions of ceramic materials (fed separately or as a mixture) form coatings applied as active layers to improve optoelectronic, photocatalysis, biocompatibility and mechanical properties such as hardness, friction, abrasion resistance, thermal and electrical insulation, corrosion resistance, and thus increase the lifetime of coated parts [202]. In the wide group of processes dedicated to ceramic coatings deposition, thermal spraying stands out due to: (i) unlimited substrate dimensions and complex shapes, (ii) stable stoichiometry of the material, (iii) high deposition efficiency, (iv) low operation costs and the most important high range of coating's thickness, from hundreds of nanometres to several millimetres [203]. The capability to deposit thick ceramic coatings is another crucial advantage to protect the substrate from premature degradation as a result of wear [204,205], corrosion [206,207] or high-temperature [208,209], etc.

However, in the conventional thermal spray processes (e.g., atmospheric plasma spraying or high-velocity oxygen fuel) the high process temperature leads to a melting of the applied material or its intensive heating with a heat source. As a result, a change in particle shape, an increase in powder particle size, phase transitions (e.g., anatase to rutile, which is less photocatalytically active), structural modification or technological defects such as porosity or micro-cracks are generated [210-214]. Eventually, the melted particles lose the characteristics and properties of the nanostructured material. Therefore, low-temperature, kinetic-based processes are sought to improve the coating's quality and fill the gap. LPCS and its vacuum modification AD are the most promising methods. 
The coatings deposition in these techniques relies on the mechanical interlocking and adhesion of the fine particles resulting in: (i) unmodified feedstock phase composition, (ii) undamaged substrate from input heat, and (iii) dense layer with unaffected powder properties [73]. Both methods enable efficient ceramic spraying. However, a proper powder preparation is needed.

\subsection{Powders Preparation}

The bonding mechanism of metallic particles in LPCS is attributed to plastic deformation at a high strain rate. The impacting metal particles show the highest shear strain at the particle's interface $[215,216]$. In contrast, the mechanism with plastic and features of inelastic deformation may occur for ceramics. However, fine particles have to be applied in the deposition process $[39,40]$. What is more, due to high-velocity ceramic particle impact, a shear strain spreads as a shear cone towards the particle centre and the maximum is obtained inside the particle. Therefore, the strain distribution in AD is much less localized than that of LPCS. Particles impact simulations performed by Daneshian et al. [40] revealed three different impact behaviours in the AD process: (i) rebounding, (ii) bonding and (iii) fragmentation. However, bonding occurred only for small particles of 25-75 nm, while particles larger than $75 \mathrm{~nm}$ were fragmented and rebound (Figure 20). It should be noted that LCPS operates at higher pressures than in AD due to the ambient atmosphere, and thus generates the bow shock in front of the substrate decelerating the particles. This phenomenon limits the application of fine ceramic particles in LPCS, as the particles would not reach the substrate. There are several requirements for powder preparation to spray ceramic particles by CS [74]: (i) nanosized particles should be agglomerated to $\mathrm{min}$. $15 \mu \mathrm{m}$ in diameter to pass through the shockwave, (ii) the agglomerates should be porous, and (iii) they should have structures with a continuous epitaxial-like crystal array across a plurality of primary particles, so that the particles can be easily fragmented and adhere during impact.
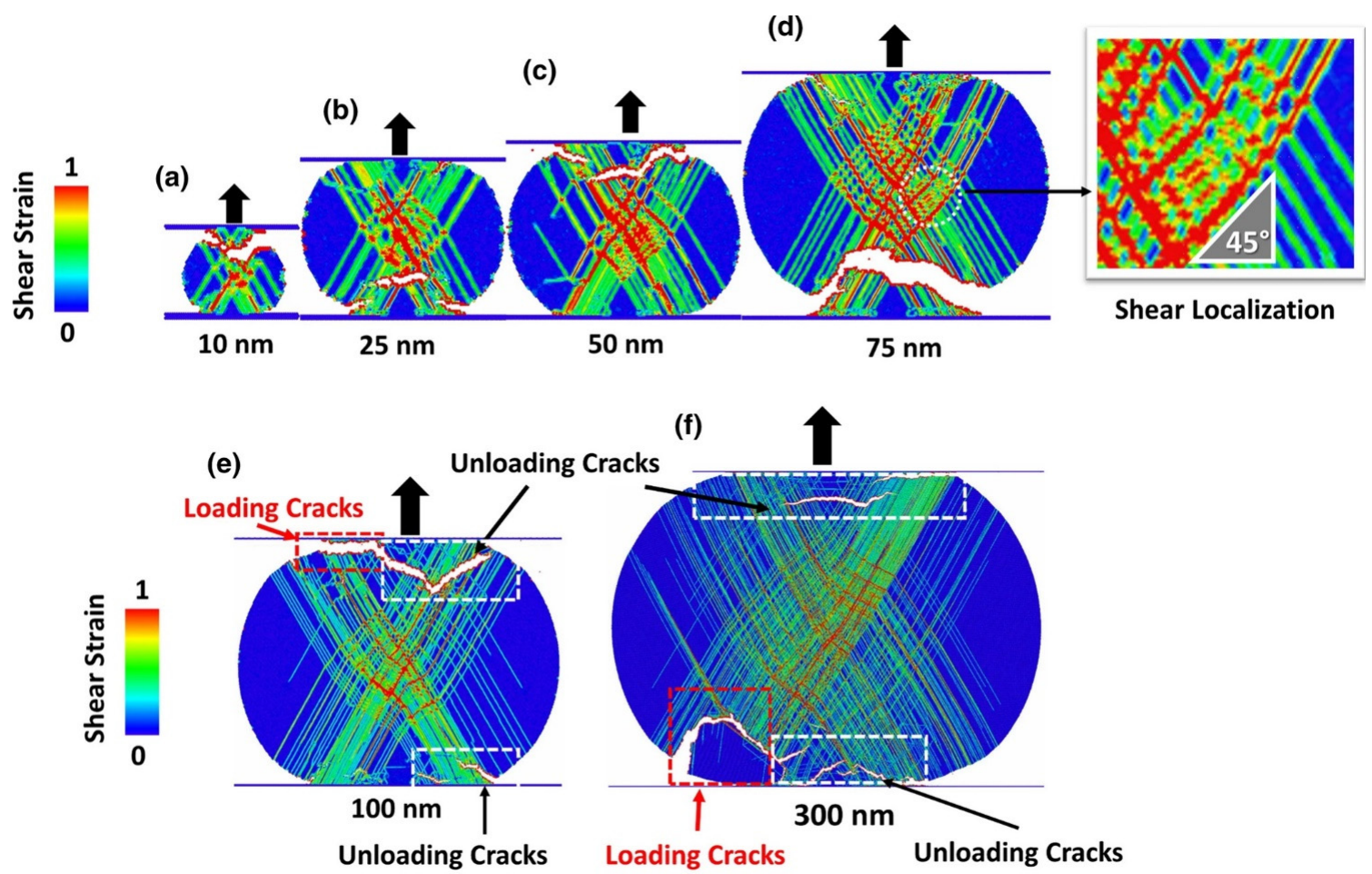

Figure 20. Simulated deformation patterns after compression loading and unloading (deformation history) by Von Mises shear strain fields inside the $\mathrm{TiO}_{2}$ particles for different initial diameters of (a) $10 \mathrm{~nm}$, (b) $25 \mathrm{~nm}$, (c) $50 \mathrm{~nm},(\mathbf{d}) 75 \mathrm{~nm},(\mathbf{e})$ $100 \mathrm{~nm}$ and (f) $300 \mathrm{~nm}$. The strain pattern reveals (i) localized plastic deformations along the slip systems and (ii) shear localization in an orientation relation of $45^{\circ}$ with respect to the loading direction [40]. 
The phenomena present during the deposition of ceramic particles by AD are similar to those occurring during LPCS. Hanft et al. [73] divided particles by the size and stage of agglomeration and described possible processes in AD (see Figure 21a). The ceramic particles size ready to bond is in the range of $200 \mathrm{~nm}-2 \mu \mathrm{m}$ at intermediate energies. As the submicron particle strikes the substrate, cracks form by whole volume and fragmentation occurs due to impact pressure. Further moving or rotating of the fragments provides arrangement and densification. Upcoming particles cause rebinding of fragments, further plastic deformation and consolidation of the deposited material. The plasticity is described by quasi-static compression and respectively determined thresholds for plasticity [217]. Ceramic agglomerates impact the substrate and due to the kinetic energy get separated into fragments. The coating formation is possible, however the quality can be worsened. Large agglomerates will erode the substrate and rebound. The coating formation can be divided according to Figure 21b into stage (1), which concerns particles impact, substrate deformation, and anchoring of the first layer, and stage (2) with subsequent film growth and particle consolidation.

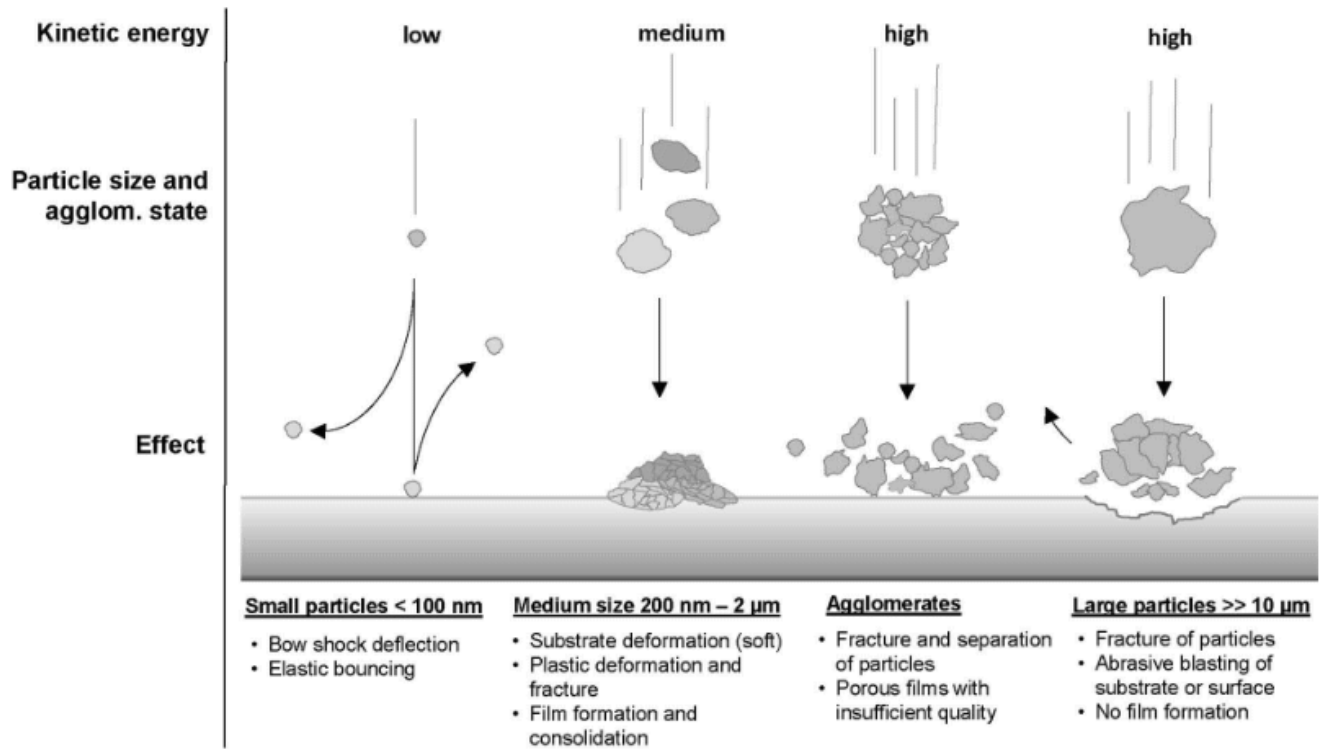

(a)

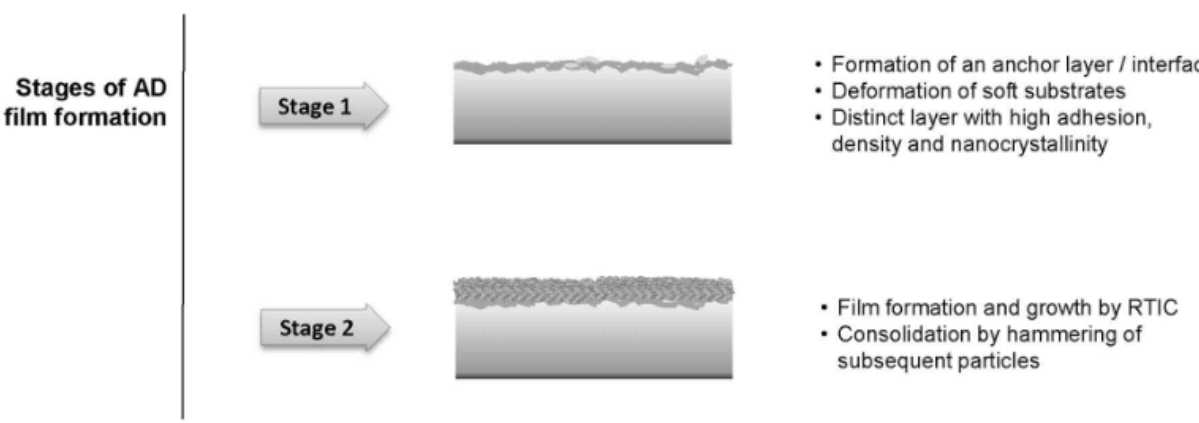

(b)

Figure 21. Possible particle-substrate interactions based on the speed and kinetic energy of the ceramic particles (a) and the room temperature impact consolidation process, with a distinction between stage 1 (anchor layer formation) and stage 2 (film buildup), during which particle hammering and fracturing takes place (b) [73].

The LPCS spraying process is performed at low temperatures, and thus there is an opportunity to use thermally sensitive materials without possible burning. To prepare ceramic powders with desired characteristics dedicated for LPCS (e.g., high purity ultrafine- 
grained powders and nanopowders), the following wet-chemical methods can be used: wet ball milling, chemical co-precipitation, spray drying, or sol-gel. Wet ball milling performed in alcohol provides an efficient environment for homogenous mixing and enables a uniform distribution of components with additional satelliting [218]. As a result, wet-milled samples have a significantly smaller standard distribution compared to air milled [219]. Saghir et al. [220] ball-milled $5 \mu \mathrm{m}$ sized plate-like alumina powder with various parameters in air and ethanol. Saghir et al. noticed that wet-milled powders underwent the greatest size reduction with a final average particle size of $0.29 \mu \mathrm{m}$ and crystallite size of 10.13 $\mathrm{nm}$ (Figure 22), while $\mathrm{Xu}$ et al. [221] wet-milled $\mathrm{ZnO}$ varistor ceramics doped with $\mathrm{Bi}_{2} \mathrm{O}_{3}$, $\mathrm{Sb}_{2} \mathrm{O}_{3}, \mathrm{Co}_{2} \mathrm{O}_{3}, \mathrm{Cr}_{2} \mathrm{O}_{3}$, and $\mathrm{MnO}$ and achieved grain refinement. Turon-Vinas et al. [222] mixed in ball mill ceria-stabilized zirconia powders with 10 and $12 \mathrm{~mol} \%$ ceria, containing 0.25 wt. $\%$ of $\mathrm{Al}_{2} \mathrm{O}_{3}$ with different amounts of $\mathrm{CaO}$ in ethanol. Turon-Vinas et al. dried the powders, sieved (315 $\mu \mathrm{m}$ mesh), applied in cold isostatic pressing and proved increased mechanical properties of the material due to reduced grain size. The fine powder resulting from wet ball milling provides high density (above 99\%) ceramic compacts in the sintering process [223].
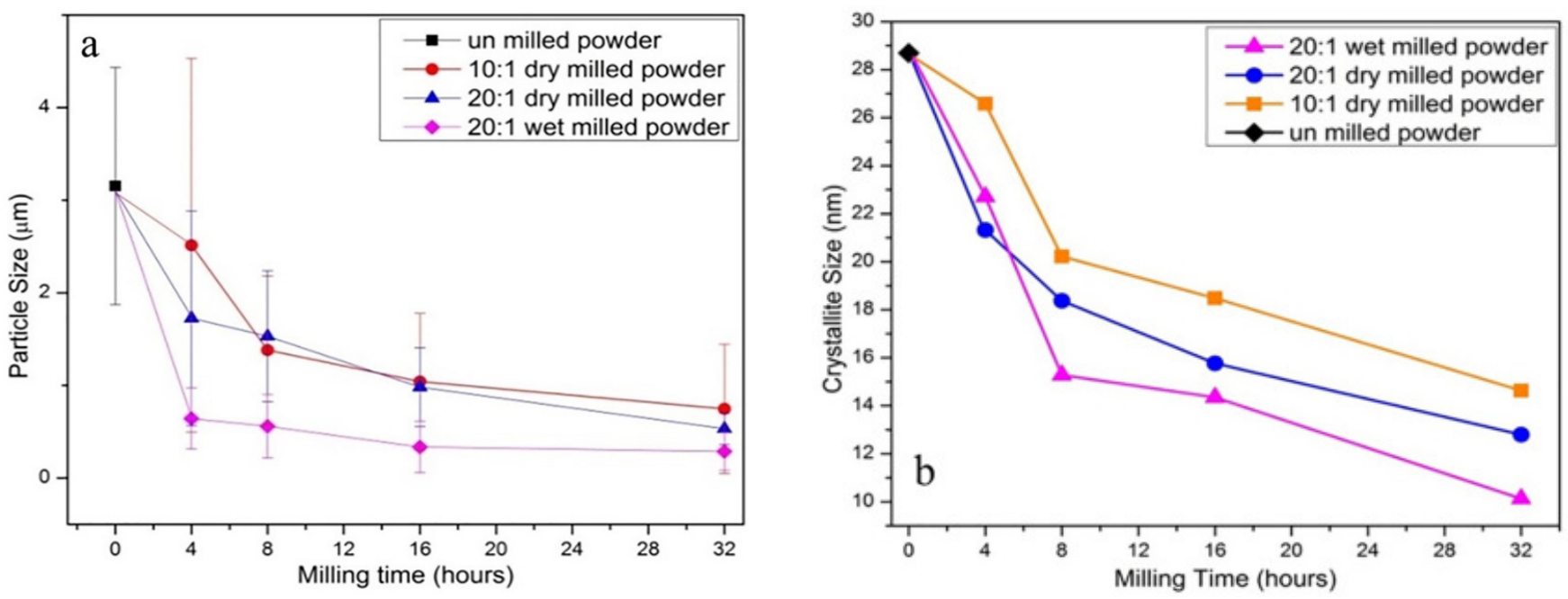

Figure 22. Particle size of plate-like alumina powders ball-milled with different parameters (a) and comparison of crystallite size (b). Reprinted with permission from [220]. Copyright 2021 Elsevier.

Chemical co-precipitation is applied to homogeneous hydrolysis of various oxides. Many papers in the literature describe the production of nano-crystalline ceramic materials, e.g., $\mathrm{ThO}_{2}$ [224], cerium doped gadolinium gallium aluminium garnet with different Y-doping levels [225], low-agglomerated Yt-doped yttria-alumina garnet (YAG) (Figure 23a) [226], Ce-doped YAG nanophosphors [227], and barium calcium zirconium titanate $(\mathrm{BCZT})\left(\left(\mathrm{Ba}_{0.85} \mathrm{Ca}_{0.15}\right)\left(\mathrm{Zr}_{0.1} \mathrm{Ti}_{0.9}\right) \mathrm{O}_{3}\right)$ with a homogeneous particle size of approximately $500 \mathrm{~nm}$ (Figure 23b) [228]. 


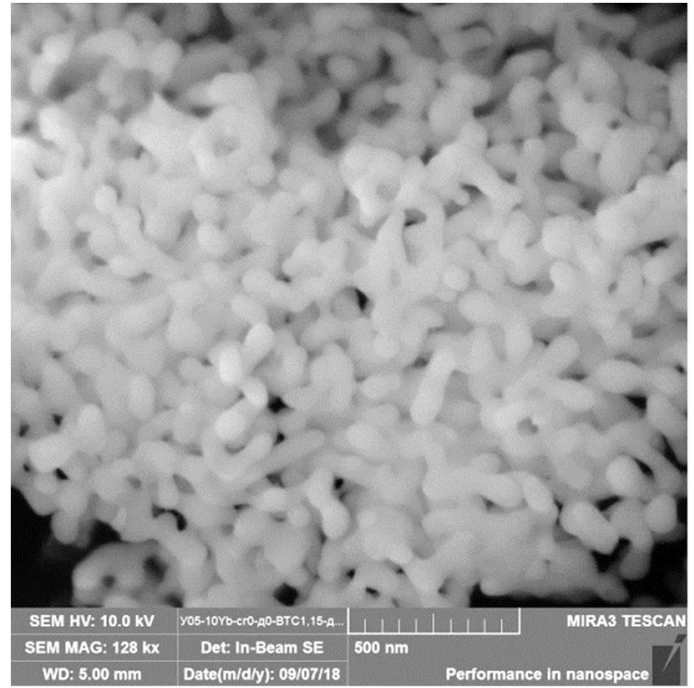

(a)
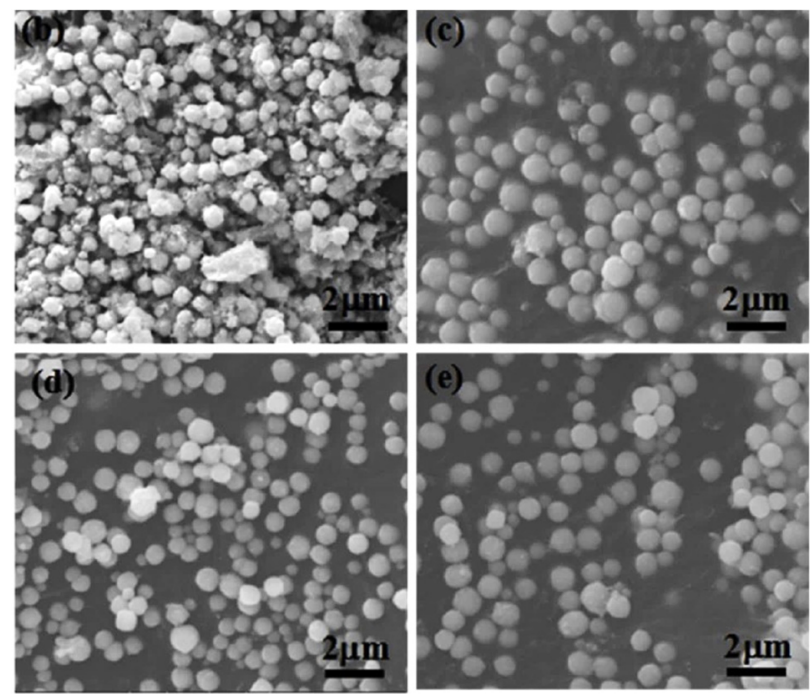

Figure 23. FESEM micrographs of the Yb:YAG ceramic nanopowder fabricated by chemical co-precipitation (a) (Reprinted with permission from [226]. Copyright 2019 Elsevier) and (b-e) SEM images of BCZT powders with different $\mathrm{NaOH}$ concentrations (Reprinted with permission from [228]. Copyright 2019 Elsevier).

A method enabling control of agglomeration size of ceramic nanoparticles is spray drying. Powders prepared by spray drying have good flowability, narrow size distribution and controllable morphology. Produced in this way powder has granulation from tens of nanometres to hundreds of micrometres and depends mostly on the atomization nozzle type. However, it should be noted that the morphology of resultant particles depends not only on the size distribution of initial ceramics but also on agglomeration tendency in the suspension and mechanical strength of the shell of a granule provided by polymer additives during the drying process [229]. The influence of binder on the morphology was analysed by Kim and Jung [230], who concluded that the sphericity of $\mathrm{Al}_{2} \mathrm{O}_{3}-\mathrm{ZrO}_{2}$ particles is improved with increasing the viscosity of the solution. On the other hand, Wang et al. [231] produced hydroxyapatite (HA) microspheres and found that the particles had spherical morphology and smooth surface (Figure 24), but did not have uniform size distributions. The mean size of the particles increased with slurry concentration and compressed air flow rate. Many studies have described the optimization of powders by spray drying for further application in thermal spraying. Bertrand et al. [232] prepared agglomerates of two oxide ceramics $\left(\mathrm{Al}_{2} \mathrm{O}_{3}\right.$ and $\left.\mathrm{Y}_{2} \mathrm{O}_{3}-\mathrm{ZrO}_{2}\right)$ and shown that there is a qualitative relation between the sedimentation behaviour and the agglomerate shape (solid or hollow), while Vicent et al. [233] applied spray drying to produce free-flowing micro-sized nanostructured agglomerated $\mathrm{TiO}_{2}$ powder ( $\mathrm{P} 25$ mixture of anatase and rutile) from nanosized particles with an average primary size of $\sim 20 \mathrm{~nm}$ for atmospheric plasma spraying process. Chahal et al. [234] used the spray drying process to prepare calcium carbonate powder for thermal spray processes and obtained large, porous, hollow, and spherical particles ranging between 14 and $201 \mu \mathrm{m}$. However, in this case, the powder had to be sieved before the spraying process. To solve the problem of particle pores, density, and size, Bian et al. [134] prepared by spray drying a nanostructured mixture of $\mathrm{Al}_{2} \mathrm{O}_{3}-13$ wt. $\% \mathrm{TiO}_{2}$ composite powders, and then heat and plasma treated. The pores in the particles were decreased after heat treatment, while plasma treatment increased the density and maintained a large number of nano-sized grains (Figure 25). 

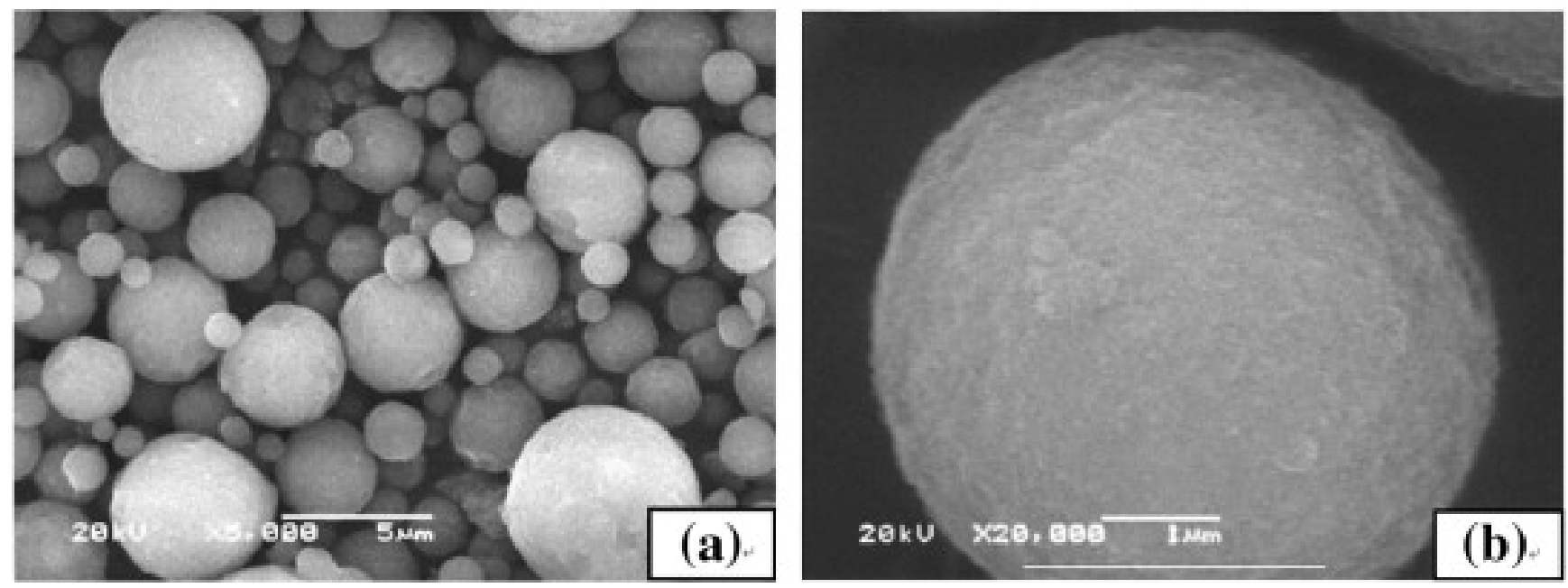

Figure 24. SEM micrographs of hydroxyapatite microspheres fabricated by spray drying: (a) overall morphology, (b) high magnification surface morphology. Reprinted with permission from [231]. Copyright 2009 Elsevier.

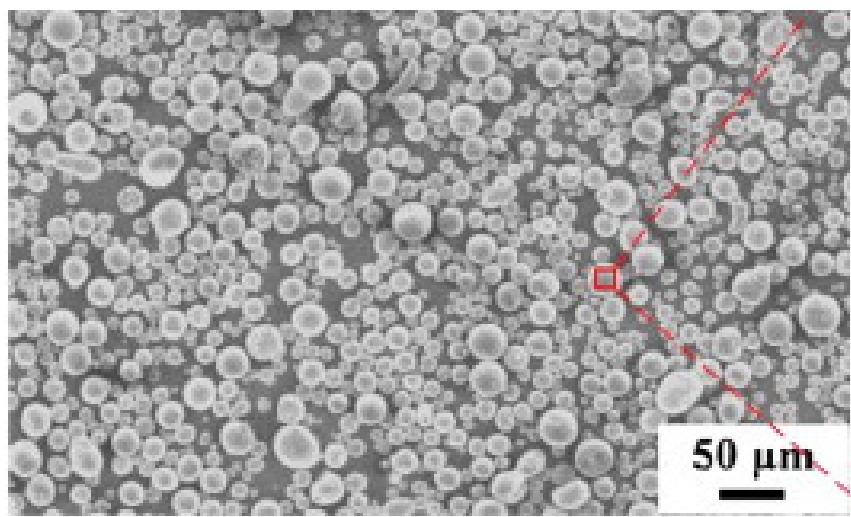

(a)

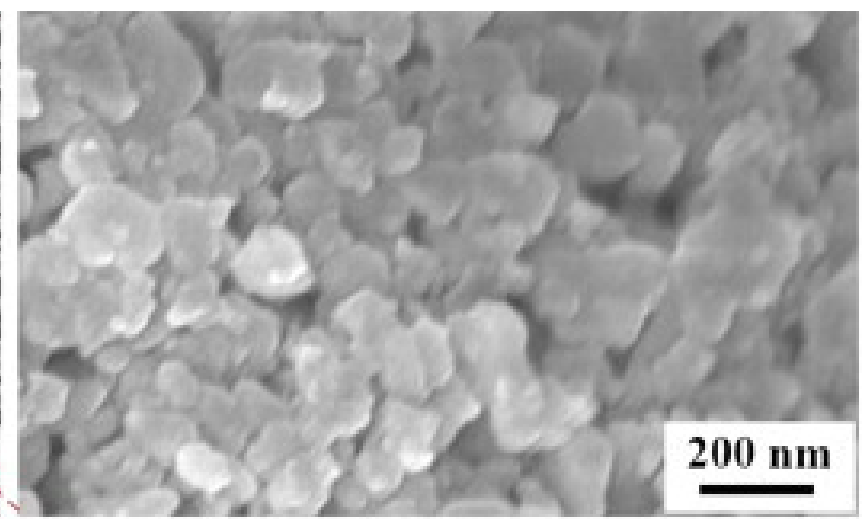

(b)

Figure 25. SEM micrographs of the plasma-treated spray-dried $\mathrm{Al}_{2} \mathrm{O}_{3}-13$ wt. $\% \mathrm{TiO}_{2}$ powders: (a) overall morphology, (b) high magnification surface morphology. Reprinted with permission from [134]. Copyright 2012 Elsevier.

The sol-gel (SG) method offers unlimited possibilities for producing different materials at room temperature. It is essential for organic or biological modifications because it does not cause thermal degradation of materials [235]. There are alternative high-temperature approaches, such as the Pechini method [236] or the combustion method [237]. The SG technique also offers unique possibilities for generating materials with different shapes because the process is performed in the liquid medium. Matrices produced in this way can be porous or dense, depending on the final application. Porosity in a material is essential for potential applications, especially when active substances change their physicochemical properties (e.g., colour) in contact with extrinsic factors (gas and liquid) coated inside the matrix. Precursors offer numerous possibilities of modification of final products by adding functional groups. As a result, material properties can be changed, e.g., the affinity of metals, flexibility, or hydrophobicity $[236,238,239]$. It is worth emphasizing that the drying step, when water and other volatile liquids are removed, can be performed at room temperature. The resulting dry amorphous powder forms agglomerates consisting of the particles linked by electrostatic or van der Waals forces. However, uncontrolled room temperature drying and ageing remove organic liquids incompletely. The synthesis remains play a role of organic binder holding particles together and can be used in powders preparation 
suiting LPCS [240-242]. Considering the strength of the attractive force between particles, two types of agglomeration can be distinguished, namely soft and hard.

In non-sintered soft agglomerates weak liquid bridge forces hold the particles together, while in the case of sintered hard aggregates, particles are bound due to chemical diffusion. The hard agglomeration generates problems with breaking down during compaction, which results in incomplete densification of the particles [243]. This may be troublesome for LPCS needs agglomerated particles of a specific size to overcome the bow shock and form a coating.

In the literature, many reports concerning various ceramic materials produced via SG can be found, e.g., $\mathrm{ZrO}_{2}-\mathrm{MgO}$ nanocomposites [244], ultrafine alumina powders $(<10 \mathrm{~nm})$ [245], AlON powders by the nitritation of SG-derived alumina nanoparticles [246], nanoscale $\mathrm{ZnTiO}_{3}$ powders [247]. In some papers, SG is paired with thermal spraying methods, of which plasma spraying is most recently applied. The SG enables various modifications of powder particle surfaces to increase the thickness of thermally sprayed coatings or enhance the adhesion force between the coating and substrate (Figure 26) [248]. However, due to nanosize combined with light weight and low density, the thermal spray coating process of nanopowders is characterized by poor flowability, leading to limited deposition and uneven coating thickness. In this case, SG can provide nano-sized powder (e.g., yttria stabilized zirconia (YSZ)) and bind its particles to microsized agglomerates by polyvinyl alcohol $[249,250]$.
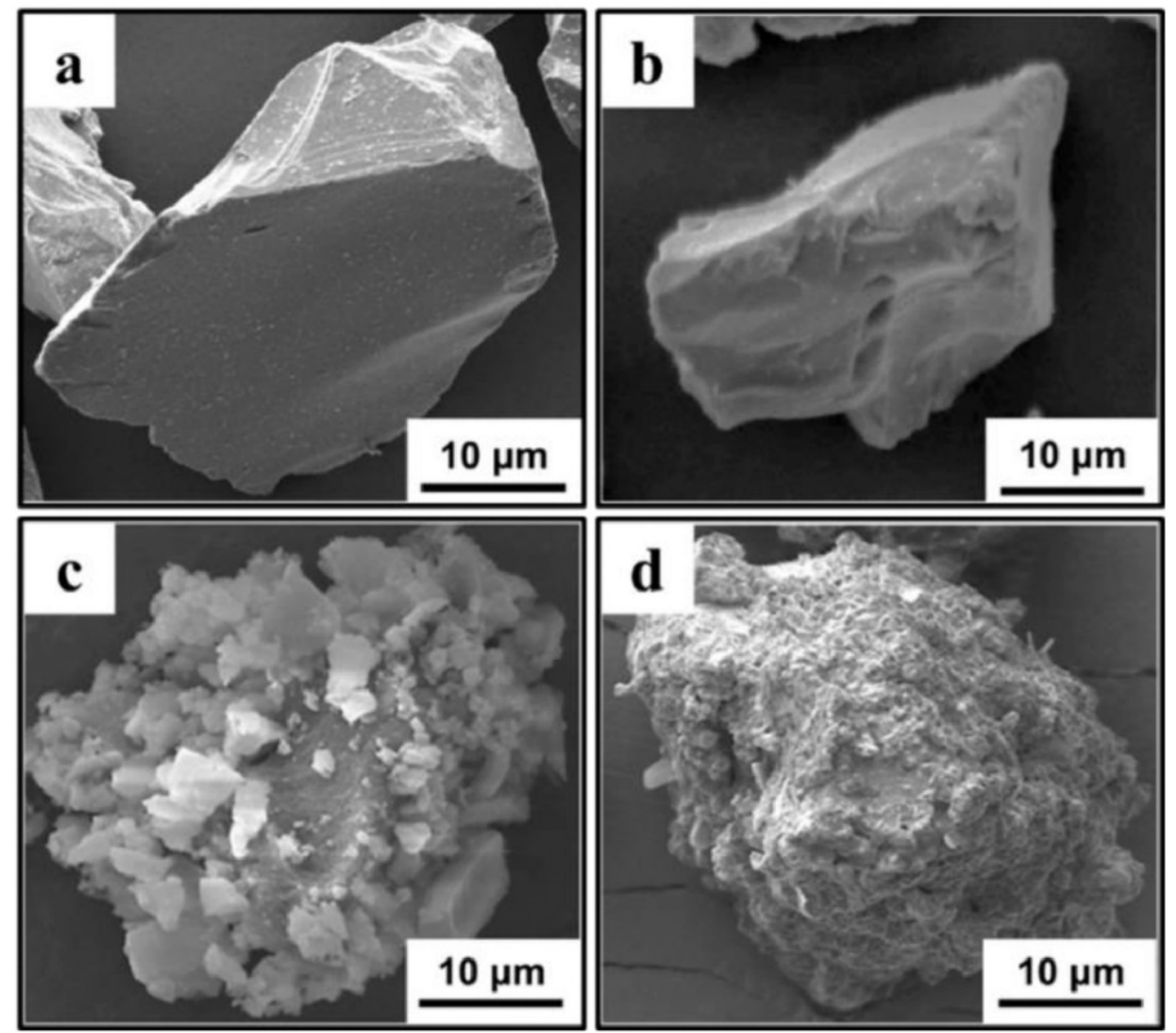

Figure 26. SEM images of commercial-SiC powder (a), commercial $\mathrm{Al}_{2} \mathrm{O}_{3}$ powder (b), SG fabricated TEOS_SiC powder (c) and SG fabricated TEOS/SDS_SiC powder (d). Reprinted with permission from [248]. Copyright 2020 Elsevier.

Powders produced by SG can be dried in various temperatures to obtain various polymorphs, for instance, $\mathrm{TiO}_{2}$ amorphous powder can be produced by drying at room temperature, while anatase and rutile by drying the same powder at 500 and $800{ }^{\circ} \mathrm{C}$, 
respectively. In my previous research, I produced nanosized $\mathrm{TiO}_{2}$ powder particles of spherical shape with sizes up to $500 \mathrm{~nm}[240,241,251]$. The size of produced agglomerates was in the range of 3.6-78.6 $\mu \mathrm{m}(\mathrm{D} 0.5=35.9 \mu \mathrm{m}), 3.4-70.4 \mu \mathrm{m}(\mathrm{D} 0.5=19.4 \mu \mathrm{m})$, and 6.9-96.7 $\mu \mathrm{m}(\mathrm{D} 0.5=35.9 \mu \mathrm{m})$, for amorphous phase, anatase, and rutile powder, respectively. The amorphous agglomerates seemed to be more porous compared to anatase or rutile (Figure 27). The size of powders was appropriate for LPCS. What is more, proper modifications ensured particles surface functionalization, e.g., by providing fluorinated groups to obtain coatings with superhydrophobic properties in further work with LPCS (Figure 28) [242]. The spraying conditions (e.g., low process temperature) minimize the heating of the powder in the working gas stream and preserve the functional material from burning or decomposition.

Amorphous
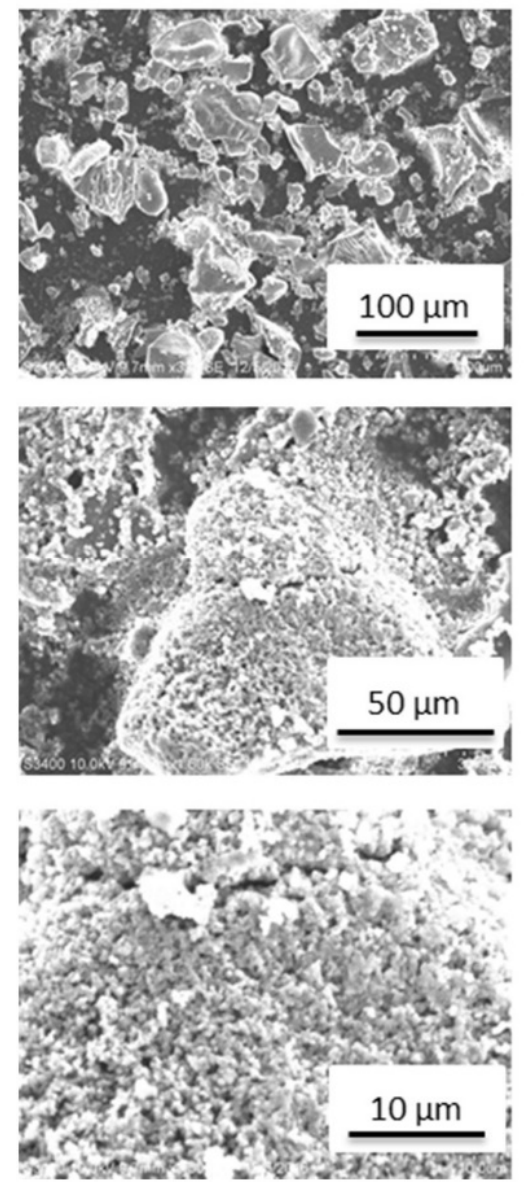

Anatase
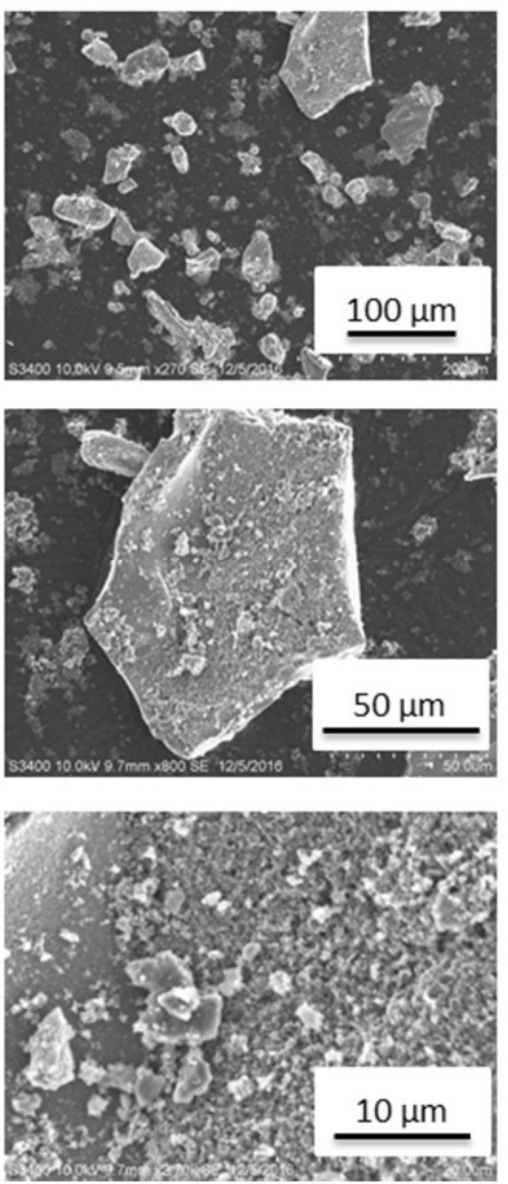

Rutile
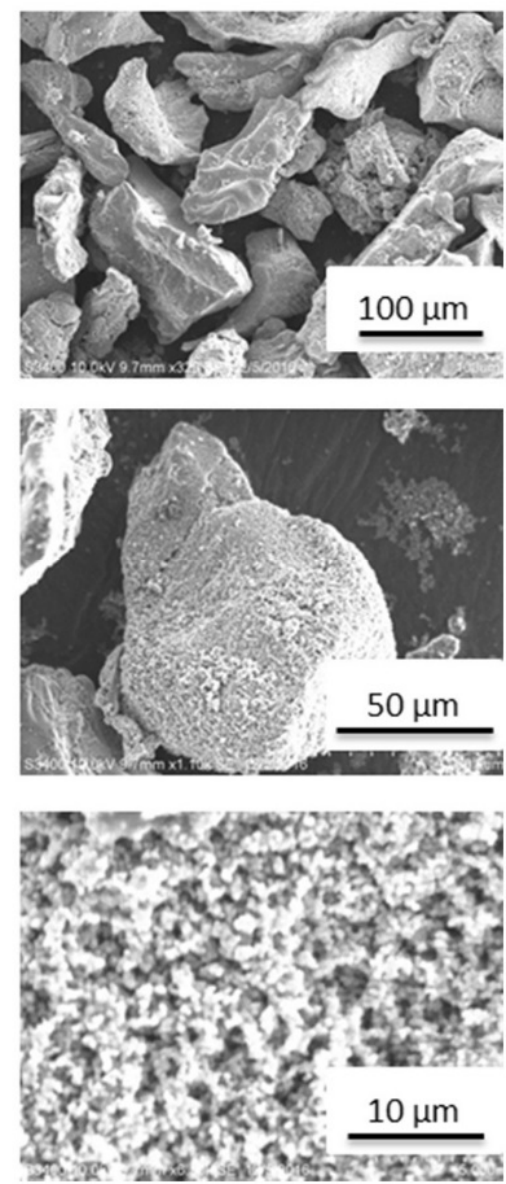

Figure 27. Micrographs (SEM, BSE) of $\mathrm{SG} \mathrm{TiO}_{2}$ various polymorph powders after synthesis. Reprinted with permission from [240]. Copyright 2019 Elsevier. 


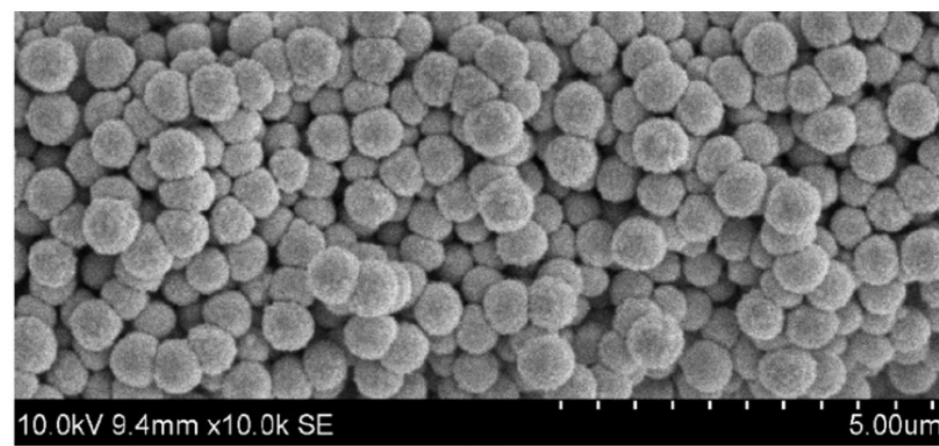

(a)

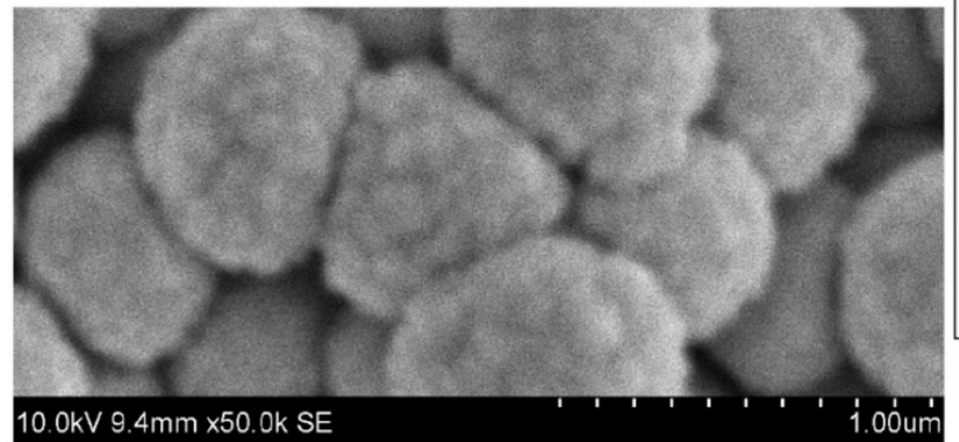

(b)

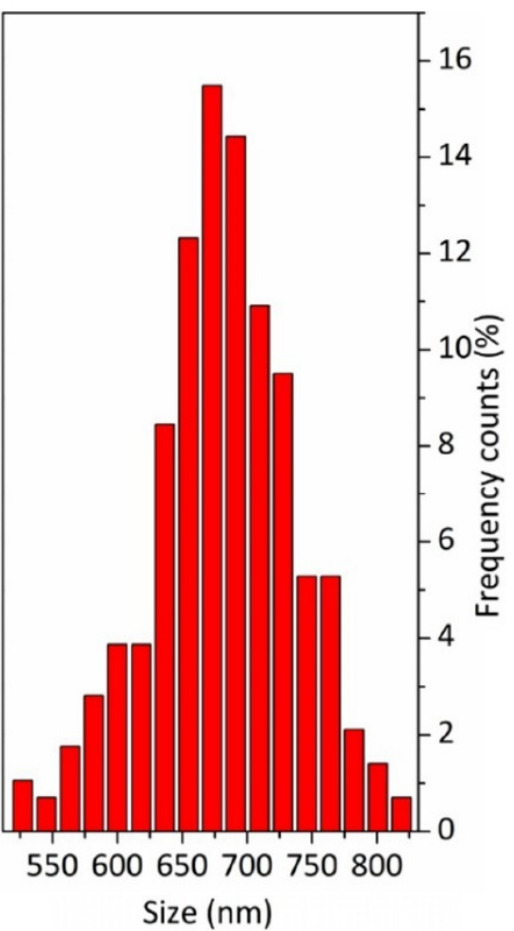

(c)

Figure 28. SEM image of SG fabricated $\mathrm{SiO}_{2}-\mathrm{F}$ powder (a) with a detailed view on FOTS-functionalized cauliflower-like silica spheres (b) and histogram of particle size distribution based on SEM imaging (c) [242].

The nanoparticles agglomeration can be improved by adding a binder. Yang et al. [252] deposited $\mathrm{TiO}_{2}$ coating with a mean thickness of 10-15 $\mu \mathrm{m}$ using anatase particles agglomerated by polyvinyl alcohol binder. Salim et al. [253] produced anatase powder by hydrolysis of $\mathrm{TiOSO}_{4}$ in distilled water with a small addition of inorganic salt (ammonium sulfate) working as a binder combined with hydrothermal post-treatment process and sprayed $150 \mu \mathrm{m}$ thick $\mathrm{TiO}_{2}$ coating. Salim et al. claimed that $\mathrm{NH}_{4}{ }^{+}$and $\mathrm{SO}_{4}{ }^{2-}$ ions adsorbed on the surface of $\mathrm{TiO}_{2}$ and post hydrothermal post-treatment favour agglomerated particles break down on impact onto the substrate due to the induced nanoporosity and were the key factor to a build-up of the coating. Further analysis performed by Toibah et al. [254] showed that adding the $\left(\mathrm{NH}_{4}\right)_{2} \mathrm{SO}_{4}$ binder enhanced the agglomeration process of $\mathrm{TiO}_{2}$ and promoted mobility of dislocation during the CS process. It should be emphasised that soft agglomerates provide higher quality coating compared to sintered aggregates, which are difficult to fracture upon impact $[73,255,256]$.

\subsection{LPCS Ceramic Coatings Applications}

Ceramic nanostructured coatings are a fundamental material of many functional applications, such as self-cleaning and antifouling surfaces [257], implants and biocompatibility [258], biomedical devices [259], tools [260], solar cells, Li-ion batteries, and solid oxides fuel cells [261]. Particular attention is paid to the nano-porous structures, which merit is extremely large surface area and other specific properties in comparison to bulk material [262]. Kinetics processes enhance ceramic particle's breaking into small fragments within coatings with defined density. As a result, some local porosity can be formed in the coatings $[240,241]$. What is more, due to high-velocity impact, impact-induced fragmentation and compression in LPCS, nanoparticles ceramic particles can provide coatings with various thicknesses [263]. In contrast to the AD method, LPCS work in atmospheric conditions and a shock wave is formed above the substrate. Therefore, agglomerated particles are needed in LPCS to enhance DE. 
Deposition of ceramic particles requires specific parameters. High pressure above $2 \mathrm{MPa}$ enables anchoring of the ceramic particles in a plastic substrate, however, incoming particles cause blasting effects resulting in defects and thin thickness of the coating $[73,254]$. Deposition of ceramics by LPCS is conditioned significantly by powder preparation method [240,241]. Amorphous agglomerated particles manufactured by the SG method and dried at room temperature showed high porosity and residue of organic binder, composed mostly of alcohol, which enabled compaction of the submicron powder particles. Application of high working gas temperature of $400{ }^{\circ} \mathrm{C}$ in LPCS resulted in crack-free and thick coating formation with amorphous $\mathrm{TiO}_{2}$ to the anatase phase transition. According to the literature [263-268] amorphous oxides, known as soft ceramics, are exhibiting remarkable plastic deformation at moderate temperatures.

CS, as a dynamic process, generates enormous amounts of kinetic energy, which is transformed into plastic deformation and enables phase transition. Therefore, controlled transitions of amorphous to crystalline phase are possible (Figure 29). The phase transition of amorphous material can be controlled by the volume fraction of the crystalline phase, which prevents propagation of the cracks and supports the formation of multiple shear bands $[269,270]$. Moreover, the deformation of amorphous ceramic can be influenced by the coexistence of the amorphous phases and crystalline phases [269-272]. Xu et al. [272] analysed amorphous ceramics in hot pressing and concluded that amorphous ceramic, as a metastable material, shows large atomic mobility and local free volume, enabling the formation of shear bands and further plastic deformation. Therefore, the mechanism responsible for ceramic deposition is based on (i) slipping or sliding of fine particles over particles and (ii) plastic deformation resulting from the amorphous state with larger atomic mobility and local free volume, which is beneficial to the formation of shear bands.

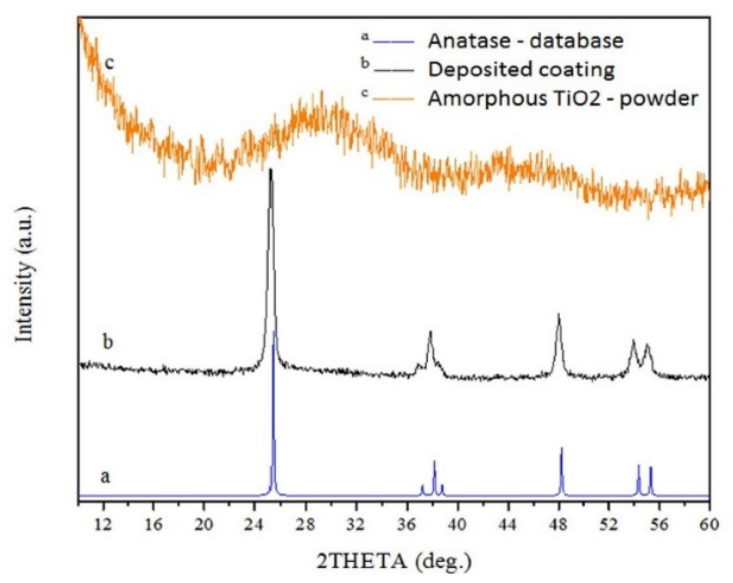

(a)

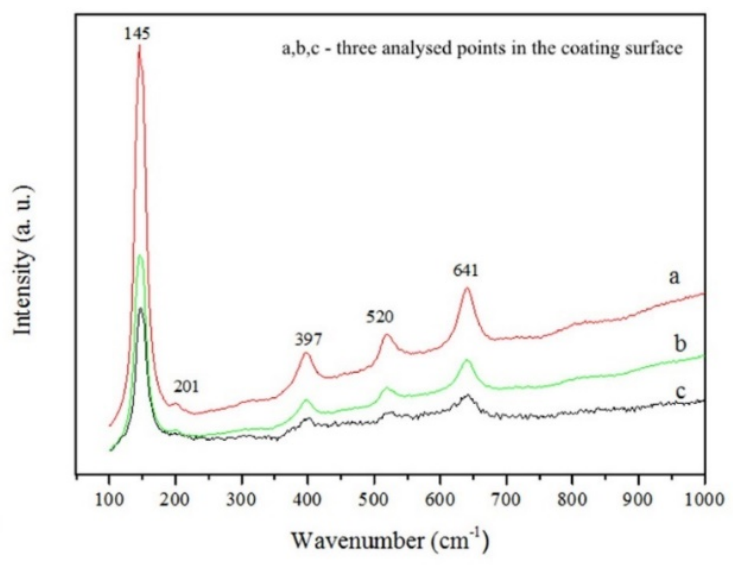

(b)

Figure 29. XRD (a) and Raman (b) spectra obtained for coating deposited of amorphous powder with the use of air preheated to $600{ }^{\circ} \mathrm{C}$. Reprinted with permission from [240]. Copyright 2019 Elsevier.

It is worth emphasising that the mechanical properties of coatings strongly depend on the type of feedstock powder and the substrate preparation method as well. The amorphous powder with an organic binder enables the deposition of a coherent coating without structural defect [240,241]. According to my previous results [251], the adhesion measured by a scratch test of anatase LPCS coating sprayed of amorphous titania powder dried at room temperature was highest among other analysed coatings. The critical load of $15.8 \mathrm{~N}$ was achieved (Figure 30). The result was comparable to the adhesion of suspension plasma sprayed rutile coating, which showed a critical load of $16.56 \mathrm{~N}$ [273]. Unfortunately, coating sprayed of anatase powder showed many defects (e.g., lamellar microcracks) which resulted mainly from differences in the thermal expansion coefficient of the metallic substrate and ceramic coating. Similar problems with microcracks and delamination of 
anatase coatings on steel substrate were noticed by Yamada et al. [274] when using nitrogen as a working gas. The coating quality was improved by applying helium.

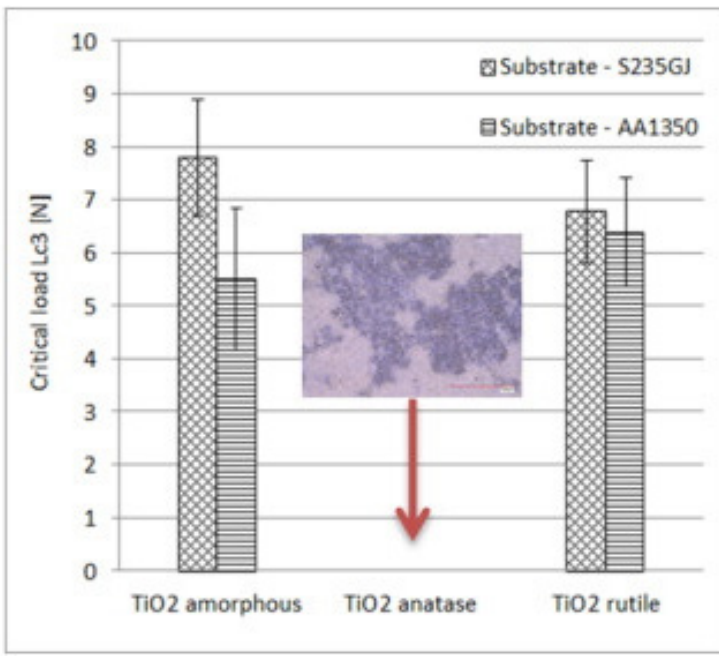

(a)

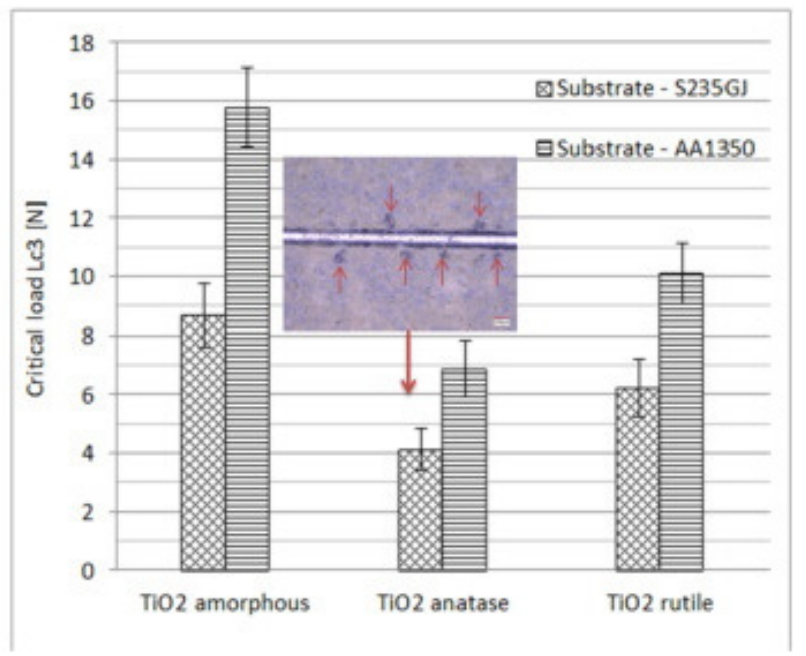

(b)

Figure 30. Critical load $\mathrm{Lc}_{3}$ results obtained for coatings deposited onto the ground (a) and grit blasted substrate (alumina grain size of $\left.\mathrm{D}_{50}=30 \mu \mathrm{m}\right)(\mathbf{b})$. Reprinted with permission from [251]. Copyright 2021 Elsevier.

Due to coatings purity, controlled phase and porosity, high adhesion and cohesion, LPCS can be applied to spray many ceramic materials. The $\mathrm{TiO}_{2}$ coating deposited on a metallic substrate improves surface properties, such as self-cleaning, anti-corrosive, or photocatalytic activity. Great potential in the processes of photocatalytic decomposition of organic pollutants gives amorphous titanium dioxide [275-278] and mixtures of crystalline polymorphs with amorphous $\mathrm{TiO}_{2}[279,280]$. It arises from specific amorphous material properties, which favours the photocatalysis process: (i) the oxygen vacancies and defect states can promote the generation of photo-induced holes and hinder the recombination of electron-hole pairs and (ii) a high specific surface area and a large number of surface reaction sites of amorphous form make the reactive surface larger than in the case of anatase [281,282]. It should be noted that the long-term operation of anatase-amorphous coatings on the aluminium substrate in a high humidity environment affects its photocatalytic activity by the amorphous transition to the anatase-brookite mixture [283]. The crystallization of brookite was activated by two factors interacting at the same time namely oxygen defects of amorphous $\mathrm{TiO}_{2}$ and the effect of moisture on this specific system. The degradation efficiency of methylene blue after $4 \mathrm{~h}$ of UV irradiation by anatase-amorphous and anatase-brookite coatings was $22 \%$ and $34 \%$, respectively [283]. Zhou et al. [284] deposited by the LPCS process an agglomerated gallium nitride $(\mathrm{GaN})$ nano-porous, thin coating (up to $10.4 \mu \mathrm{m}$ ) on stainless steel and achieved photocatalytic activities of about $33 \%$. The obtained result was $9 \%$ higher compared to the powder and arose from the higher specific surface area and roughness that the coatings exhibit after the breakage of the particles during the cold spray. It is worth emphasizing that LPCS can be used to spray $\mathrm{TiO}_{2}$ onto thermally sensitive materials, such as polymers, providing new opportunities for coupled materials [285]. Fan et al. [286] sprayed nanocrystalline $\mathrm{TiO}_{2}$ by the vacuum $\mathrm{AD}$ process and obtained a similar coating consisting of agglomerated particles with a thickness of several hundred nanometers and a mesoporous microstructure for applications as photocatalytic degradation and dye-sensitized solar cells.

Ceramic coatings can be also applied successfully for biomedical applications [287-289]. Hydroxyapatite (HA) compared to titanium shows high bioactivity due to increased osseointegration capacities and similar chemical composition of the bone [290]. LPCS can restrain temperature drawbacks present in plasma spraying of HA, such as evaporation, 
phase alteration, residual stress, deboning or gas release [291]. Vilardell et al. [292] worked on Ti6Al4V substrate preparation to successfully spray hydroxyapatite (HA). The best quality and DE showed HA coatings deposited by LPCS onto a very rough and porous HPCS Ti bond coat. The HA particles impact the bond coat surface and anchor properly by filling up the valleys of the surface roughness. According to the dilatometry graph, two different thermal treatments were performed at 1000 and $1400{ }^{\circ} \mathrm{C}$ to densify the coating structure (Figure 31). Apart from substrate surface roughness, there are other process parameters, such as standoff distance, substrate heating temperature, and the number of sprays, which influences the HA coating properties. Moreover, despite the ideal bioactive compatibility of HA, low mechanical strength limits its use in loaded implants. Therefore Hasniyati et al. [293] used the design of experiment and analysed the effects of input LPCS process parameters on the thickness, nanohardness, and elastic modulus of the HA coating deposited on pure $\mathrm{Mg}$. The optimized HA coating was $49.77 \mu \mathrm{m}$ thick, with nanohardness and elastic modulus of $462.61 \mathrm{MPa}$ and $45.69 \mathrm{GPa}$, respectively.
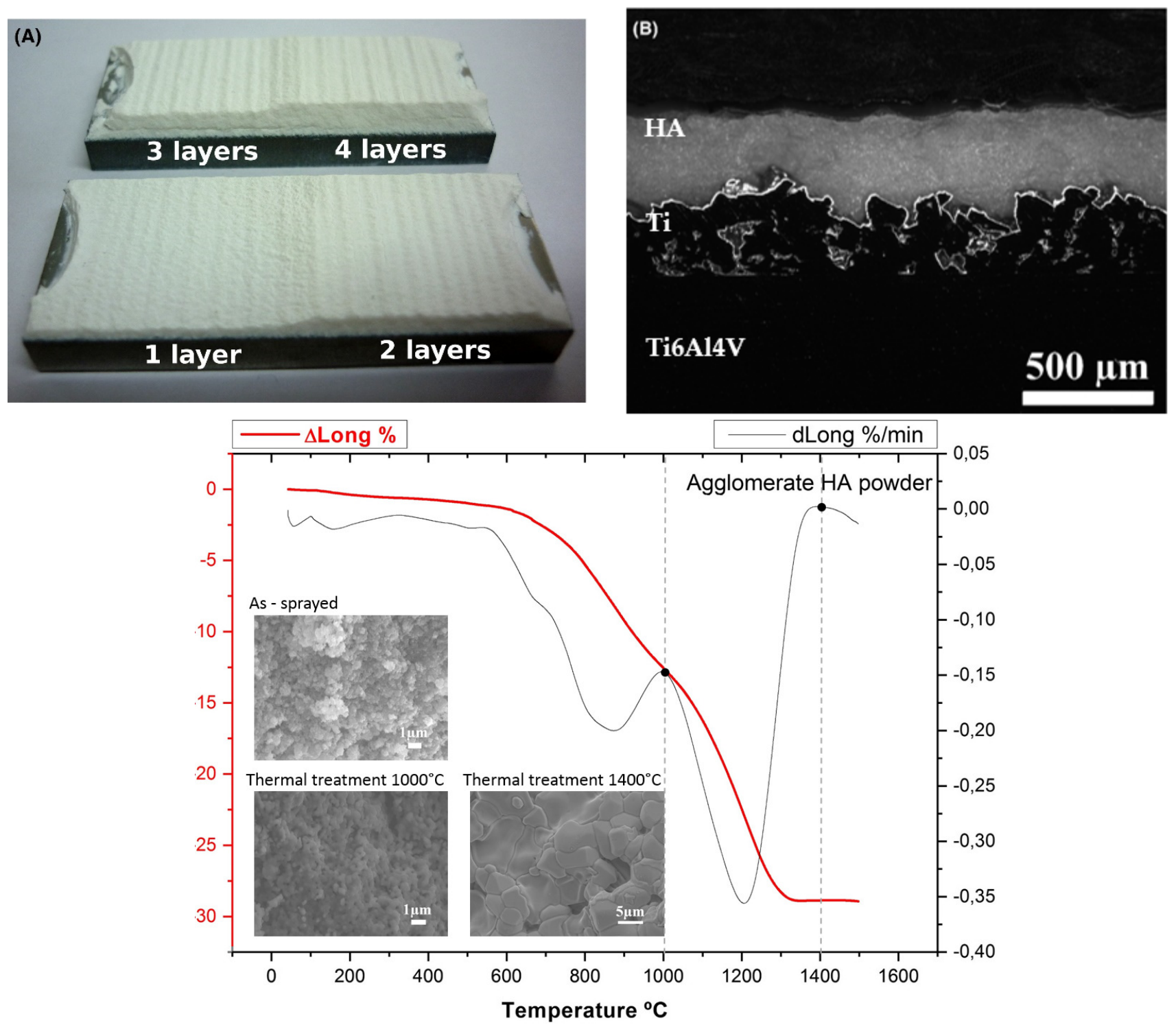

(C)

Figure 31. Macrograph (A), micrograph optical image (B) and dilatometry of HA coating (C) obtained by LPCS on Ti bond coat. Reprinted with permission from [292]. Copyright 2018 John Wiley and Sons. 
The particles agglomeration was used to spray other types of ceramic materials by LPCS, such as $\mathrm{WO}_{3}, \mathrm{SiC}, \mathrm{SiO}_{2}$. Tungsten trioxide is mostly applied for: (i) hydrogen detection, (ii) fuel cell electrodes, (iii) photoanodes in photoelectrochemical cells for water splitting, pollutants degradation, air purification, and as an antimicrobial agent [294]. To produce $\mathrm{WO}_{3}$ coatings, Lee et al. [295] sprayed aggregated particles of 30-50 $\mu \mathrm{m}$ size, which were shattered and fractured upon impact on the substrate. Formed coatings had a thickness of up to $2 \mu \mathrm{m}$ and consisted of very fine secondary particles, which provided good adherence and void reduction in the coating. In another study, Lee et al. tested $\mathrm{WO}_{3}$ and $\mathrm{Y}_{2} \mathrm{O}_{3}$ LPCS coating and noticed, that particles closest to the substrate were finer and better packed due to fragmentation of impacting agglomerates (Figure 32) [296]. The $\mathrm{SiC}$ is applied for anti-oxidation at elevated temperatures due to thermophysical properties and the possibility of formation of a thin amorphous $\mathrm{SiO}_{2}$ with appropriate fluidity and low oxidation diffusion coefficient as well [297]. Seo et al. [298] sprayed a rough and porous $\mathrm{SiC}$ powder with a mean size of $17 \mu \mathrm{m}$ powder, which was crushed due to impact into nanometre-sized particles and anchored in Inconel 625 substrate. The anti-oxidation of the metallic substrate was three times higher compared to the uncoated substrate. What is more, a significant effect on the Inconel 625 protection from oxygen diffusion played $\mathrm{SiO}_{2}$ thin film formed beneath $\mathrm{SiC}$. The silica coating is an attractive material for hydrophobic [299] or hydrophilic [300] applications, depending on material functionalization. Therefore, combining various techniques (e.g., SG method for powder material production and LPCS for coating deposition) enables functionalization of the substrate surface. The SG synthesis allows full control of produced oxide materials with provided deformability due to amorphous form. Submicron silica particles covered with $\mathrm{C}_{14} \mathrm{H}_{19} \mathrm{~F}_{13} \mathrm{O}_{3} \mathrm{Si}$ shell support multilevel roughness of coating and enhance the coating hydrophobicity [242]. The surface of as-sprayed $\mathrm{SiO}_{2}$ coatings modified with $0.15 \mathrm{~mL}$ $\mathrm{C}_{14} \mathrm{H}_{19} \mathrm{~F}_{13} \mathrm{O}_{3} \mathrm{Si}$ gave the highest contact angle (CA) of $153.7^{\circ}$. The coating maintains its superhydrophobic properties in severe conditions, which confirmed durability tests consisting of: (i) sliding sample surface on the surface of 800-grit sandpaper (Figure 33a), (ii) two-hours annealing at different temperatures varying from 50 to $500{ }^{\circ} \mathrm{C}$ and quenching in the air in (Figure 33b), (iii) immersion in water and absolute alcohol (Figure 33c), and (iv) ultrasonic bath in absolute alcohol (Figure 33d). It was concluded that merely hightemperature treatment can significantly reduce hydrophobic properties by decomposition of the functionalizing precursor, $\mathrm{C}_{14} \mathrm{H}_{19} \mathrm{~F}_{13} \mathrm{O}_{3} \mathrm{Si}$.

Table 4 shows the main applications of ceramic coatings produced by LPCS.

Table 4. Selected applications of the LPCS ceramic coatings.

\begin{tabular}{|c|c|c|c|}
\hline Powder Material & Powder Preparation Method & Coating Application & Reference \\
\hline $\mathrm{TiO}_{2}$ (various polymorphs) & Sol-gel & Photocatalyst & {$[240,241,283]$} \\
\hline $\mathrm{GaN}$ & $\mathrm{N} / \mathrm{A}$ & Photocatalyst & [284] \\
\hline HA & Spray drying & Biomedical & [292] \\
\hline $\mathrm{WO}_{3}$ & $\mathrm{~N} / \mathrm{A}$ & $\begin{array}{c}\text { fuel cell electrodes, } \\
\text { photoanodes in } \\
\text { photoelectrochemical cells for } \\
\text { water splitting }\end{array}$ & [295] \\
\hline $\mathrm{SiC}$ & $\mathrm{N} / \mathrm{A}$ & $\begin{array}{c}\text { anti-oxidation at elevated } \\
\text { temperatures }\end{array}$ & [298] \\
\hline $\mathrm{SiO}_{2}$ & Sol-gel & hydrophobic surfaces & [242] \\
\hline
\end{tabular}




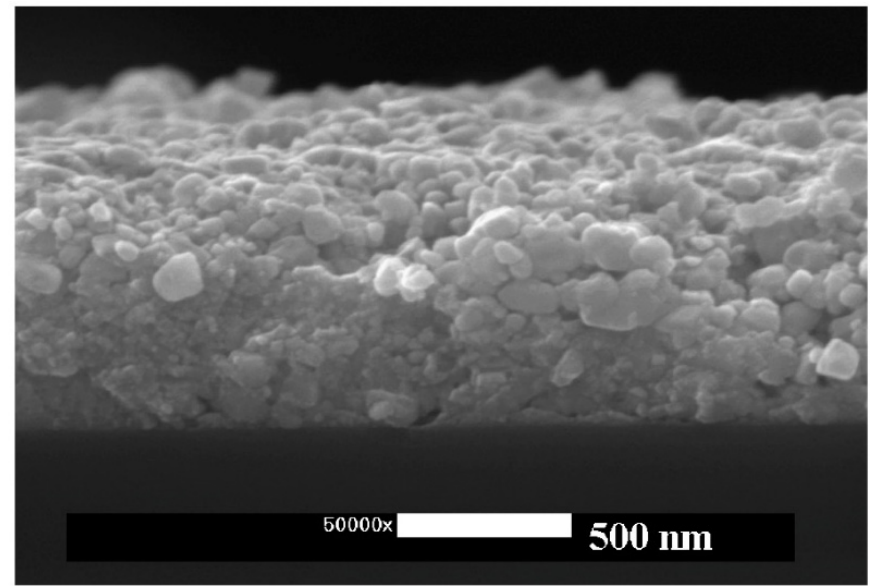

(a)

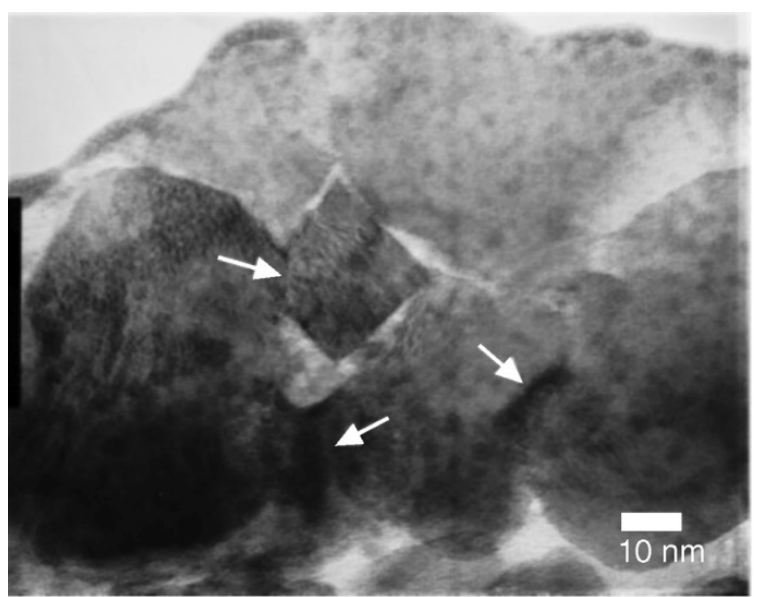

(b)

Figure 32. Cross-section of the $\mathrm{WO}_{3}$ film sprayed by the LPCS process on the silicon substrate: FESEM (a) and TEM (b) images [298]. Reprinted with permission from [296]. Copyright 2004 Elsevier. Arrows indicate single fine particles interlocking.

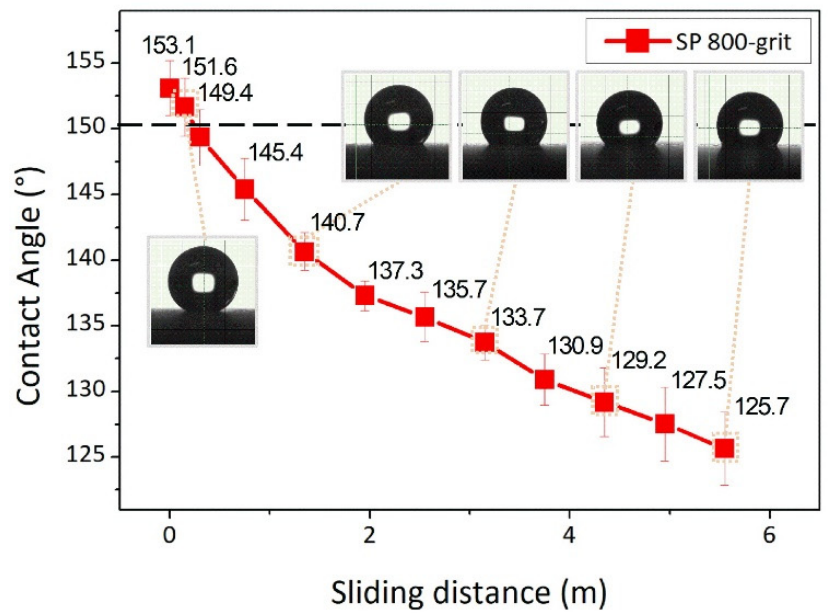

(a)

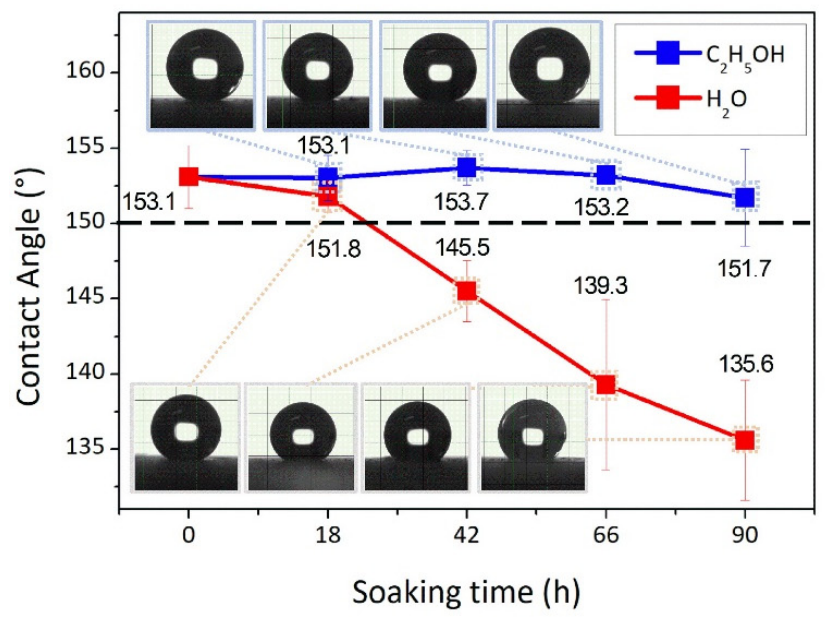

(c)

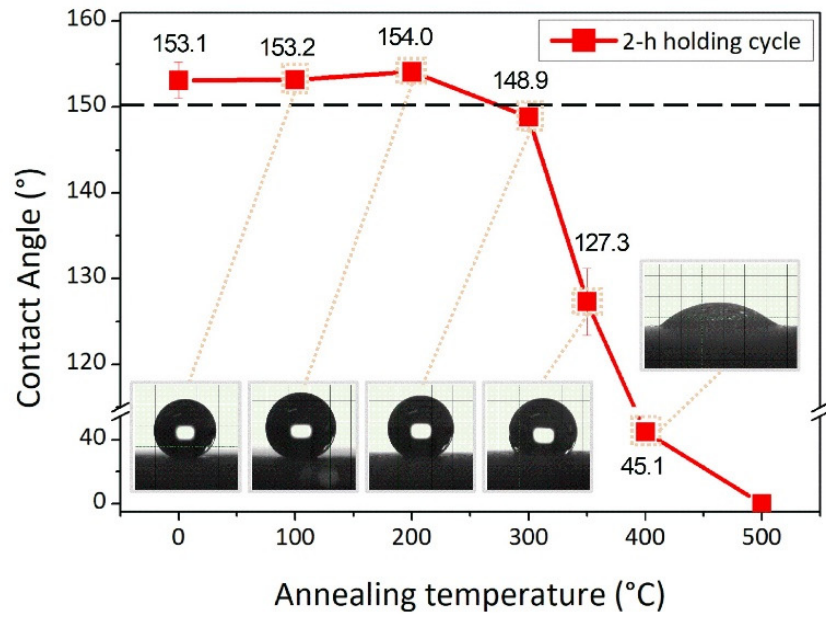

(b)

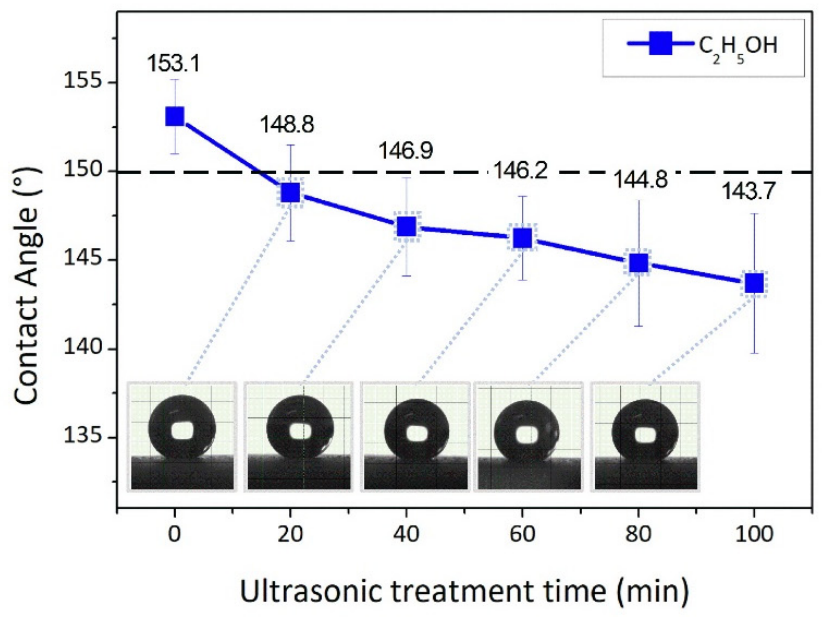

(d)

Figure 33. Wettability of $\mathrm{SiO} 2-\mathrm{F}$ coating sprayed on alumina substrate as a measure of contact angle after durability test being: (a) abrasive wear test on 800-grid sandpaper, (b) heat treatment in 2-h annealing cycles, (c) immersion in water and absolute alcohol and (d) ultrasonic bath treatment in absolute alcohol. The dashed line represents the superhydrophobic limit for CA being $150^{\circ}$ [242]. 


\section{Future Perspectives}

The combination of the CS process with the appropriate powder preparation method opens new possibilities in surface engineering. The fabrication of nanostructured functional CS coatings is promising in many non-traditional fields, e.g., photocatalysis [283,284], dyesensitized solar cell [301,302], electro-ceramic for piezoelectric devices and electro-optic materials for optical devices [50,303] solid oxide fuel cells [304-306], bioactivity [307-310]. The spraying process is increasingly operator-friendly, as troublesome technical aspects are being eliminated, e.g., nozzle clogging is solved by water cooling system, fine agglomerating particles are fed by aerosol powder feeders, the powder particles velocity is easily increased in the newest units by increased parameter ranges, the gas pressure up to 10 $\mathrm{MPa}$, and the gas temperature up to $1100{ }^{\circ} \mathrm{C}$. It should be noted that there are applications in which technologically more advanced HPCS can be replaced by LPCS. For example, ceramic deposition is processed with low working gas pressure. On the other hand, HPCS increase the plastic deformation of metal particles in metal-ceramic mixtures and, as a result, increase DE and coating compactness as well. Therefore, the increased range of spraying parameters in newly produced cold spray units, especially working gas pressures, seems to be sensible in the case of MMC coatings deposition. However, in this solution, the gas consumption extremally increases process costs. As described above various CS coatings indicate that the basic process limitation has been overcome, as high content MMC composite and pure ceramic coatings are being sprayed extending significantly process applications. Further CS experiments should be concentrated on the following challenges: (i) selecting optimal parameters for powder preparation to CS; (ii) applying of ceramic or metal-ceramic powder material modifications or CS process optimization, e.g., new nozzle design, to spray highly coherent coatings without vacuum or further PSHT; (iii) balancing work hardening with toughness and ductility of MMC coating by CS parameters adjustment mainly for additive manufacturing applications; (iv) tailoring the ratio, size, concentration, and distribution of ceramic phase in the deposited MMC coating; (v) analyzing nonmetallic substrates preparation method, e.g., surface texturing, for improved bonding; (vi) selecting parameters to control the phase transition, e.g., amorphous to anatase in the spraying process or intermetallic formation in PSHT.

\section{Conclusions}

CS is one of the most intensively developed techniques among thermal spraying methods. The benefits of CS arising from the utilization of high kinetic energy instead of thermal energy makes it a perfect technology for the deposition of various materials. Due to the considerably higher DE of HPCS, for many years LPCS was considered only a budget version of CS. Nevertheless, the latest research results showed significant progress and new possibilities of the LPCS. The DE in LPCS is usually improved by mixing soft metal powder with hard phase (e.g., ceramic powder), which provides a tamping effect and increases plastic deformation. Furthermore, to increase $\mathrm{DE}$ without additional processes (e.g., oxide reduction), LPCS parameters should be optimized, such as: (i) particle size, (ii) working gas, as well as (iii) nozzle length and expansion ratio.

A basic method to deposit ceramic particles by LCPS is the application of PRMMC with a controlled admixture of metal powder to work as a binder. Kinetic spraying provides many merits, such as: lack of tensile thermal stresses, uncontrolled phase transformation, decarburization, oxidation, or high porosity. The mixture of ductile matrix and hard reinforcement phase result in combined properties of the PRMMC LPCS coatings. The powders mixture can be prepared by: (i) mechanical blending of powders, (ii) satelliting, (iii) powder cladding, (iv) mechanical ball milling, (v) ball milling combined with SHS, and (vi) spray drying. Each method has its advantages and disadvantages. Mechanical blending is a common technique. However, it has some limitations, e.g., different sizes of particles, morphology, or density, which result in various ranges of particles velocities and thus divergence in DE and nonuniform ceramic and metal distribution. By spray drying, powder agglomerates can be produced, increasing coating uniformity. A high 
and controlled volume fraction of the hard phase can be provided by powder cladding. Ball milling ensures composites with well-dispersed nano-sized particles. Nevertheless, due to enhanced work hardening of the ductile phase, the DE of the mixture in LPCS can be decreased. A proper powder preparation increases the ceramic content in the coatings. However, despite the dominating contribution of ceramic powder in the mixture, a significant part will rebound, decreasing the ceramic DE. The bonding mechanism of ceramic in PRMMC LPCS coatings is based on the plastic deformation of metallic particles at a high strain rate. The impacting metal particles show the highest shear strain at the particle's interface. Nevertheless, metal-ceramic LPCS coatings show advanced functionality and include many applications.

Deposition of pure ceramic powder by LPCS is more complicated as the material is brittle. The mechanism with plastic and features of inelastic deformation may occur for ceramics. However, fine particles have to be applied in the deposition process. In LPCS, the stream of particles has to overcome the air atmosphere, which decelerates the particles. Therefore, increased working gas velocity should be used. As a result, a bow shock forms above the substrate and ejects fine particles from the stream. There are several requirements for powder preparation to spray ceramic particles by LPCS: (i) nanosized particles should be agglomerated to overcome bow shock, (ii) the agglomerates should be porous to fracture and (iii) have structures with a continuous epitaxial-like crystal array. Due to high-velocity impact, impact-induced fragmentation, and compression in LPCS, nanoparticles ceramic particles can provide coatings with various thicknesses.

The preparation of agglomerated ceramic powders with advisable characteristics dedicated for LPCS can be performed by several wet-chemical methods: wet ball milling, chemical co-precipitation, spray drying, or sol-gel. Due to wet condition powders having a significantly smaller standard distribution of particles and controllable morphology compared to air milled, the SG method offers additionally unlimited possibilities of producing different materials at room temperature with controlled porosity. The resulting dry amorphous powder forms agglomerates consisting of the particles linked by electrostatic or van der Waals forces. Such soft agglomerates provide higher quality LPCS coating compared to sintered aggregates, which are difficult to fracture upon impact. The amorphous oxides are exhibiting remarkable plastic deformation at moderate temperatures, and due to enormous kinetic energy in the LPCS process, controlled phase transition into crystalline phase can be initiated. Therefore, the mechanism responsible for ceramic deposition is based on the following steps: (i) slipping or sliding of fine particles over particles and (ii) plastic deformation resulting from the amorphous state with larger atomic mobility and local free volume, which is beneficial to the formation of shear bands.

The deposition of pure ceramic coatings opens new applications for LPCS. However, much more work is needed to explore new horizons and further possibilities of the CS method.

Funding: The research was funded by the Polish National Science Centre under contract No. 2016/23/D/ST8/00675 (Project title: The mechanism of joining submicron ceramic particles in cold spraying process).

Institutional Review Board Statement: Not applicable.

Informed Consent Statement: Not applicable.

Data Availability Statement: Not applicable.

Acknowledgments: Author would like to thank Agnieszka Baszczuk, Marek Jasiorski and Anna Gibas for all suggestions and many constructive talks.

Conflicts of Interest: The author declares no conflict of interest. 


\section{References}

1. Papyrin, A. Cold Spray Technology, 1st ed.; Elsevier: Oxford, UK, 2007.

2. Alkimov, A.P.; Kosarev, V.F.; Nesterovich, N.I.; Papyrin, A.N. Method of Applying Coatings. Russian Patent No. 1618778, 8 September 1990.

3. Alkhimov, A.P.; Kosarev, V.F.; Nesterovich, N.I.; Papyrin, A.N.; Shushpanov, M.M. Device for Applying Coatings. Russian Patent No. 1618777, 8 September 1990.

4. Alkhimov, A.P.; Kosarev, V.F.; Nesterovich, N.I.; Papyrin, A.N. Method of Applying of Metal Powder Coatings. Russian Patent No. 1773072, 1 July 1992.

5. Alkhimov, A.P.; Kosarev, V.F.; Papyrin, A.N. A method of cold gas-dynamic deposition. Sov. Phys. Dokl. 1990, $35,1047-1049$.

6. Alkimov, A.P.; Papyrin, A.N.; Kosarev, V.F.; Nesterovich, N.I.; Shushpanov, M.M. Gas Dynamic Spraying Method for Applying a Coating. U.S. Patent No. 5,302,414, 12 April 1994.

7. Alkimov, A.P.; Papyrin, A.N.; Kosarev, V.F.; Nesterovich, N.I.; Shushpanov, M.M. Method and Device for Coating. European Patent No. 0484533, 25 January 1995.

8. Borchers, C.; Gärtner, F.; Stoltenhoff, T.; Assadi, H.; Kreye, H. Microstructural and macroscopic properties of cold sprayed copper coatings. J. Appl. Phys. 2003, 93, 10064-10070. [CrossRef]

9. Maev, R.G.; Leshchynsky, V. Air gas dynamic spraying of powder mixtures: Theory and application. J. Therm. Spray Technol. 2006, 15, 198-205. [CrossRef]

10. Grujicic, M.; Zhao, C.L.; Tong, C.; DeRosset, W.S.; Helfritch, D. Analysis of the impact velocity of powder particles in the cold-gas dynamic-spray process. Mater. Sci. Eng. A 2004, 368, 222-230. [CrossRef]

11. Van Steenkiste, T.H.; Smith, J.R.; Teets, R.E.; Moleski, J.J.; Gorkiewicz, D.W.; Tison, R.P.; Marantz, D.R.; Kowalsky, K.A.; Riggs, W.L.; Zajchowski, P.H.; et al. Kinetic spray coatings. Surf. Coat. Technol. 1999, 111, 62-71. [CrossRef]

12. Sobolev, V.; Guilemany, J.; Nutting, J. High Velocity Oxy Fuel Spraying: Theory, Structure-Property Relationsh, 1st ed.; Money Publishing: London, UK, 2004.

13. Rezaeain, A.; Chromik, R.; Yue, S.; Irissou, E.; Legoux, J.-G. Characterization of cold-sprayed Ni, Ti and cu coating properties for their optimizations. In Proceedings of the Thermal Spray 2008: Thermal Spray Crossing Borders, Maastricht, The Netherlands, 2 June 2008; DVS: Maastricht, The Netherlands, 2009; pp. 854-860.

14. Zou, Y.; Qin, W.; Irissou, E.; Legoux, J.-G.; Yue, S.; Szpunar, J.A. Dynamic recrystallization in the particle/particle interfacial region of cold-sprayed nickel coating: Electron backscatter diffraction characterization. Scr. Mater. 2009, 61, 899-902. [CrossRef]

15. Kairet, T.; Di Stefano, G.; Degrez, M.; Campana, F.; Janssen, J.-P. Comparison between coatings from two different copper powders: Mechanical properties, hardness and bond strength. In Proceedings of the Thermal Spray 2006: Building on 100 Years of Success, Seattle, WA, USA, 15 May 2006; ASM International: Seattle, WA, USA, 2006; pp. 854-860.

16. Stoltenhoff, T.; Kreye, H.; Richter, H.J. An analysis of the cold spray process and its coatings. J. Therm. Spray Technol. 2002, 11, 542-550. [CrossRef]

17. Van Steenkiste, T.H.; Smith, J.R.; Teets, R.E. Aluminum coatings via kinetic spray with relatively large powder particles. Surf. Coat. Technol. 2002, 154, 237-252. [CrossRef]

18. Schmidt, T.; Gärtner, F.; Assadi, H.; Kreye, H. Development of a generalized parameter window for cold spray deposition. Acta Mater. 2006, 54, 729-742. [CrossRef]

19. Shin, S.; Yoon, S.; Kim, Y.; Lee, C. Effect of particle parameters on the deposition characteristics of a hard/soft-particles composite in kinetic spraying. Surf. Coat. Technol. 2006, 201, 3457-3461. [CrossRef]

20. Li, C.-J.; Li, W.-Y.; Liao, H. Examination of the critical velocity for deposition of particles in cold spraying. J. Therm. Spray Technol. 2006, 15, 212-222. [CrossRef]

21. Ning, X.-J.; Jang, J.-H.; Kim, H.-J. The effects of powder properties on in-flight particle velocity and deposition process during low pressure cold spray process. Appl. Surf. Sci. 2007, 253, 7449-7455. [CrossRef]

22. Katanoda, H.; Fukuhara, M.; Iino, N. Numerical study of combination parameters for particle impact velocity and temperature in cold spray. J. Therm. Spray Technol. 2007, 16, 627-633. [CrossRef]

23. Alkhimov, A.P.; Klinkov, S.V.; Kosarev, V.F. Experimental study of deformation and attachment of microparticles to an obstacle upon high-rate impact. J. Appl. Mech. Tech. Phys. 2000, 41, 245-250. [CrossRef]

24. Li, C.-J.; Wang, H.-T.; Zhang, Q.; Yang, G.-J.; Li, W.-Y.; Liao, H.L. Influence of spray materials and their surface oxidation on the critical velocity in cold spraying. J. Therm. Spray Technol. 2010, 19, 95-101. [CrossRef]

25. Gilmore, D.L.; Dykhuizen, R.C.; Neiser, R.A.; Roemer, T.J.; Smith, M.F. Particle velocity and deposition efficiency in the cold spray process. J. Therm. Spray Technol. 1999, 8, 576-582. [CrossRef]

26. Assadi, H.; Schmidt, T.; Richter, H.; Kliemann, J.-O.; Binder, K.; Gärtner, F.; Klassen, T.; Kreye, H. On parameter selection in cold spraying. J. Therm. Spray Technol. 2011, 20, 1161-1176. [CrossRef]

27. Maev, R.G.; Leshchynsky, V. Introduction to Low Pressure Gas Dynamic Spray: Physics and Technology, 1st ed.; WILEY-VCH: Weinheim, Germany, 2008.

28. Moridi, A.; Hassani-Gangaraj, S.M.; Guagliano, M.; Dao, M. Cold spray coating: Review of material systems and future perspectives. Surf. Eng. 2014, 30, 369-395. [CrossRef]

29. Kumar, S.; Kumar, M.; Jindal, N. Overview of cold spray coatings applications and comparisons: A critical review. World J. Eng. 2020, 17, 27-51. [CrossRef] 
30. Luo, X.-T.; Yang, G.-J.; Li, C.-J. Multiple strengthening mechanisms of cold-sprayed CBNp/NiCrAl composite coating. Surf. Coat. Technol. 2011, 205, 4808-4813. [CrossRef]

31. Xie, X.; Chen, C.; Chen, Z.; Addad, A.; Xie, Y.; Wu, H.; Verdy, C.; Wang, Y.; Wang, J.; Ren, Z.; et al. Effect of annealing treatment on microstructure and mechanical properties of cold sprayed TiB2/AlSi10Mg composites. Surf. Interfaces 2021, 26, 101341. [CrossRef]

32. Sova, A.; Maestracci, R.; Jeandin, M.; Bertrand, P.; Smurov, I. Kinetics of composite coating formation process in cold spray: Modelling and experimental validation. Surf. Coat. Technol. 2017, 318, 309-314. [CrossRef]

33. Wang, X.; Zhang, B.; Lv, J.; Yin, S. Investigation on the clogging behavior and additional wall cooling for the axial-injection cold spray nozzle. J. Therm. Spray Technol. 2015, 24, 696-701. [CrossRef]

34. Koivuluoto, H.; Larjo, J.; Marini, D.; Pulci, G.; Marra, F. Cold-sprayed Al6061 coatings: Online spray monitoring and influence of process parameters on coating properties. Coatings 2020, 10, 348. [CrossRef]

35. Fernandez, R.; Jodoin, B. Cold spray aluminum-Alumina cermet coatings: Effect of alumina content. J. Therm. Spray Technol. 2018, 27, 603-623. [CrossRef]

36. Poza, P.; Garrido-Maneiro, M.Á. Cold-sprayed coatings: Microstructure, mechanical properties, and wear behaviour. Prog. Mater Sci. 2021, 100839. [CrossRef]

37. Triantou, K.I.; Pantelis, D.I.; Guipont, V.; Jeandin, M. Microstructure and tribological behavior of copper and composite copper+alumina cold sprayed coatings for various alumina contents. Wear 2015, 336-337, 96-107. [CrossRef]

38. Tao, Y.; Xiong, T.; Sun, C.; Jin, H.; Du, H.; Li, T. Effect of $\alpha-\mathrm{Al}_{2} \mathrm{O}_{3}$ on the Properties of cold sprayed $\mathrm{Al} / \alpha-\mathrm{Al} 2 \mathrm{O} 3 \mathrm{composite}$ coatings on AZ91D magnesium alloy. Appl. Surf. Sci. 2009, 256, 261-266. [CrossRef]

39. Elsenberg, A.; Busato, M.; Gärtner, F.; List, A.; Bruera, A.; Bolelli, G.; Lusvarghi, L.; Klassen, T. Influence of MAX-Phase deformability on coating formation by cold spraying. J. Therm. Spray Technol. 2021, 30, 617-642. [CrossRef]

40. Daneshian, B.; Gaertner, F.; Assadi, H.; Hoeche, D.; Weber, W.; Klassen, T. Size effects of brittle particles in aerosol depositionMolecular dynamics simulation. J. Therm. Spray Technol. 2021, 30, 503-522. [CrossRef]

41. Karthikeyan, J. The Advantages And Disadvantages Of The Cold Spray Coating Process. In The Cold Spray Materials Deposition Process; Champagne, V.K., Ed.; Woodhead Publishing Series in Metals and Surface Engineering; Woodhead Publishing: Cambridge, UK, 2007; pp. 62-71.

42. Dorfman, M.R. Thermal Spray Coatings. In Handbook of Environmental Degradation of Materials, 3rd ed.; Kutz, M., Ed.; William Andrew Publishing: Norwich, NY, USA, 2018; pp. 469-488. ISBN 978-0-323-52472-8.

43. Champagne, V.; Helfritch, D. Critical assessment 11: Structural repairs by cold spray. Mater. Sci. Technol. 2015, 31, 627-634. [CrossRef]

44. Champagne, V.K., Jr.; Ozdemir, O.; Nardi, A.; (Eds.). Practical Cold Spray; Springer International Publishing: Cham, Switzerland, 2021; ISBN 978-3-030-70055-3.

45. Kovarik, O.; Siegl, J.; Cizek, J.; Chraska, T.; Kondas, J. Fracture toughness of cold sprayed pure metals. J. Therm. Spray Technol. 2020, 29, 147-157. [CrossRef]

46. Silvello, A.; Cavaliere, P.; Rizzo, A.; Valerini, D.; Dosta Parras, S.; Garcia Cano, I. Fatigue bending behavior of cold-sprayed nickel-based superalloy coatings. J. Therm. Spray Technol. 2019, 28, 930-938. [CrossRef]

47. Guerreiro, B.; Vo, P.; Poirier, D.; Legoux, J.-G.; Zhang, X.; Giallonardo, J.D. Factors affecting the ductility of cold-sprayed copper coatings. J. Therm. Spray Technol. 2020, 29, 630-641. [CrossRef]

48. Irissou, E.; Legoux, J.-G.; Arsenault, B.; Moreau, C. Investigation of Al-Al2O3 cold spray coating formation and properties. J. Therm. Spray Technol. 2007, 16, 661-668. [CrossRef]

49. Moreau, D.; Borit, F.; Corté, L.; Guipont, V. Cold spray coating of submicronic ceramic particles on poly(Vinyl Alcohol) in dry and hydrogel states. J. Therm. Spray Technol. 2017, 26, 958-969. [CrossRef]

50. Akedo, J. Room temperature impact consolidation (RTIC) of fine ceramic powder by aerosol deposition method and applications to microdevices. J. Therm. Spray Technol. 2008, 17, 181-198. [CrossRef]

51. Yang, G.-J.; Gao, P.-H.; Li, C.-X.; Li, C.-J. Simultaneous strengthening and toughening effects in WC-(NanoWC-Co). Scr. Mater. 2012, 66, 777-780. [CrossRef]

52. Yang, G.-J.; Gao, P.-H.; Li, C.-X.; Li, C.-J. Mechanical property and wear performance dependence on processing condition for cold-sprayed WC-(NanoWC-Co). Appl. Surf. Sci. 2015, 332, 80-88. [CrossRef]

53. Cho, S.; Takagi, K.; Kwon, H.; Seo, D.; Ogawa, K.; Kikuchi, K.; Kawasaki, A. Multi-walled carbon nanotube-reinforced copper nanocomposite coating fabricated by low-pressure cold spray process. Surf. Coat. Technol. 2012, 206, 3488-3494. [CrossRef]

54. Gardon, M.; Fernández-Rodríguez, C.; Garzón Sousa, D.; Doña-Rodríguez, J.M.; Dosta, S.; Cano, I.G.; Guilemany, J.M. Photocatalytic activity of nanostructured anatase coatings obtained by cold gas spray. J. Therm. Spray Technol. 2014, 23, 1135-1141. [CrossRef]

55. Ogawa, K.; Ito, K.; Ichimura, K.; Ichikawa, Y.; Ohno, S.; Onda, N. Characterization of low-pressure cold-sprayed aluminum coatings. J. Therm. Spray Technol. 2008, 17, 728-735. [CrossRef]

56. Sova, A.; Papyrin, A.; Smurov, I. Influence of ceramic powder size on process of cermet coating formation by cold spray. J. Therm. Spray Technol. 2009, 18, 633-641. [CrossRef]

57. Sova, A.; Kosarev, V.F.; Papyrin, A.; Smurov, I. Effect of ceramic particle velocity on cold spray deposition of metal-ceramic coatings. J. Therm. Spray Technol. 2011, 20, 285-291. [CrossRef] 
58. Meyer, M.C.; Yin, S.; McDonnell, K.A.; Stier, O.; Lupoi, R. Feed rate effect on particulate acceleration in cold spray under low stagnation pressure conditions. Surf. Coat. Technol. 2016, 304, 237-245. [CrossRef]

59. Grigoriev, S.; Okunkova, A.; Sova, A.; Bertrand, P.; Smurov, I. Cold spraying: From process fundamentals towards advanced applications. Surf. Coat. Technol. 2015, 268, 77-84. [CrossRef]

60. Koivuluoto, H.; Honkanen, M.; Vuoristo, P. Cold-sprayed copper and tantalum coatings-Detailed FESEM and TEM analysis. Surf. Coat. Technol. 2010, 204, 2353-2361. [CrossRef]

61. Winnicki, M.; Małachowska, A.; Dudzik, G.; Rutkowska-Gorczyca, M.; Marciniak, M.; Abramski, K.; Ambroziak, A.; Pawłowski, L. Numerical and experimental analysis of copper particles velocity in low-pressure cold spraying process. Surf. Coat. Technol. 2015, 268, 230-240. [CrossRef]

62. Winnicki, M.; Małachowska, A.; Baszczuk, A.; Rutkowska-Gorczyca, M.; Kukla, D.; Lachowicz, M.; Ambroziak, A. Corrosion protection and electrical conductivity of copper coatings deposited by low-pressure cold spraying. Surf. Coat. Technol. 2017, 318, 90-98. [CrossRef]

63. Melendez, N.M.; McDonald, A.G. Development of WC-based metal matrix composite coatings using low-pressure cold gas dynamic spraying. Surf. Coat. Technol. 2013, 214, 101-109. [CrossRef]

64. Cavaliere, P. Cold-Spray Coatings: Recent Trends and Future Perspectives, 1st ed.; Springer International Publishing: Cham, Switzerland, 2018.

65. Kulmala, M.; Vuoristo, P. Influence of process conditions in laser-assisted low-pressure cold spraying. Surf. Coat. Technol. 2008, 202, 4503-4508. [CrossRef]

66. Małachowska, A.; Winnicki, M.; Konat, Ł.; Piwowarczyk, T.; Pawłowski, L.; Ambroziak, A.; Stachowicz, M. Possibility of spraying of copper coatings on polyamide 6 with low pressure cold spray method. Surf. Coat. Technol. 2017, 318, 82-89. [CrossRef]

67. Małachowska, A.; Winnicki, M.; Stachowicz, M.; Korzeniowski, M. Metallisation of polycarbonates using a low pressure cold spray method. Surf. Eng. 2018, 34, 251-258. [CrossRef]

68. Winnicki, M.; Kozerski, S.; Małachowska, A.; Pawłowski, L.; Rutkowska-Gorczyca, M. Optimization of ceramic content in nickel-alumina composite coatings obtained by low pressure cold spraying. Surf. Coat. Technol. 2021, 405, 126732. [CrossRef]

69. Raoelison, R.N.; Aubignat, E.; Planche, M.-P.; Costil, S.; Langlade, C.; Liao, H. Low pressure cold spraying under 6bar pressure deposition: Exploration of high deposition efficiency solutions using a mathematical modelling. Surf. Coat. Technol. 2016, 302, 47-55. [CrossRef]

70. Pattison, J.; Celotto, S.; Khan, A.; O’Neill, W. Standoff distance and bow shock phenomena in the cold spray process. Surf. Coat. Technol. 2008, 202, 1443-1454. [CrossRef]

71. Schmidt, T.; Assadi, H.; Gärtner, F.; Richter, H.; Stoltenhoff, T.; Kreye, H.; Klassen, T. From particle acceleration to impact and bonding in cold spraying. J. Therm. Spray Technol. 2009, 18, 794-808. [CrossRef]

72. Kliemann, J.-O.; Gutzmann, H.; Gärtner, F.; Hübner, H.; Borchers, C.; Klassen, T. Formation of cold-sprayed ceramic titanium dioxide layers on metal surfaces. J. Therm. Spray Technol. 2011, 20, 292-298. [CrossRef]

73. Hanft, D.; Exner, J.; Schubert, M.; Stöcker, T.; Fuierer, P.; Moos, R. An overview of the aerosol deposition method: Process fundamentals and new trends in materials applications. J. Ceram. Sci. Tech. 2015, 06, 147-182. [CrossRef]

74. Shinoda, K.; Gärtner, F.; Lee, C.; Dolatabadi, A.; Johnson, S. Kinetic spraying of brittle materials: From layer formation to applications in aerosol deposition and cold gas spraying. J. Therm. Spray Technol. 2021, 30, 471-479. [CrossRef]

75. Glosse, P.; Denneler, S.; Stier, O.; Moos, R. Investigation of the powder aerosol deposition method using shadowgraph imaging. Materials 2021, 14, 2502. [CrossRef]

76. Akedo, J. Aerosol deposition of ceramic thick films at room temperature: Densification mechanism of ceramic layers. J. Am. Ceram. Soc. 2006, 89, 1834-1839. [CrossRef]

77. Xie, X.; Yin, S.; Raoelison, R.; Chen, C.; Verdy, C.; Li, W.; Ji, G.; Ren, Z.; Liao, H. Al matrix composites fabricated by solid-state cold spray deposition: A critical review. J. Mater. Sci. Technol. 2021, 86, 20-55. [CrossRef]

78. Nishida, Y. Introduction to Metal Matrix Composites: Fabrication and Recycling, 1st ed.; Springer: Tokyo, Japan, 2013.

79. Munagala, V.N.V.; Chromik, R.R. The role of metal powder properties on the tribology of cold sprayed Ti6Al4V-TiC metal matrix composites. Surf. Coat. Technol. 2021, 411, 126974. [CrossRef]

80. Munday, G.; Hogan, J.; McDonald, A. On the microstructure-dependency of mechanical properties and failure of low-pressure cold-sprayed tungsten carbide-nickel metal matrix composite coatings. Surf. Coat. Technol. 2020, 396, 125947. [CrossRef]

81. Winnicki, M.; Małachowska, A.; Rutkowska-Gorczyca, M.; Sokołowski, P.; Ambroziak, A.; Pawłowski, L. Characterization of cermet coatings deposited by low-pressure cold spraying. Surf. Coat. Technol. 2015, 268, 108-114. [CrossRef]

82. Winnicki, M.; Baszczuk, A.; Jasiorski, M.; Małachowska, A. Corrosion resistance of copper coatings deposited by cold spraying. J. Therm. Spray Technol. 2017, 26, 1935-1946. [CrossRef]

83. El-Aziz, K.A.; Saber, D.; Sallam, H.E.-D.M. Wear and corrosion behavior of Al-Si matrix composite reinforced with alumina. J. Bio.-Tribo.-Corros. 2015, 1, 5. [CrossRef]

84. Szala, M.; Łatka, L.; Walczak, M.; Winnicki, M. Comparative study on the cavitation erosion and sliding wear of cold-sprayed $\mathrm{Al} / \mathrm{Al} 2 \mathrm{O} 3$ and $\mathrm{Cu} / \mathrm{Al} 2 \mathrm{O} 3$ coatings, and stainless steel, aluminium alloy, copper and brass. Metals 2020, 10, 856. [CrossRef]

85. Hu, Y.; Cong, W. A review on laser deposition-additive manufacturing of ceramics and ceramic reinforced metal matrix composites. Ceram. Int. 2018, 44, 20599-20612. [CrossRef] 
86. Weber, L.; Dorn, J.; Mortensen, A. On the electrical conductivity of metal matrix composites containing high volume fractions of non-conducting inclusions. Acta Mater. 2003, 51, 3199-3211. [CrossRef]

87. Clyne, T.W. Thermal and Electrical Conduction in Metal Matrix Composites. In Comprehensive Composite Materials II; Beaumont, P.W.R., Zweben, C.H., Eds.; Elsevier: Oxford, UK, 2018; pp. 188-212.

88. Qu, X.; Zhang, L.; Wu, M.; Ren, S. Review of metal matrix composites with high thermal conductivity for thermal management applications. Prog. Nat. Sci. Mater. Int. 2011, 21, 189-197. [CrossRef]

89. King, P.C.; Zahiri, S.H.; Jahedi, M.Z. Rare earth/metal composite formation by cold spray. J. Therm. Spray Technol. 2008, 17, 221-227. [CrossRef]

90. Li, C.-J.; Yang, G.-J. Relationships between feedstock structure, particle parameter, coating deposition, microstructure and properties for thermally sprayed conventional and nanostructured WC-Co. Int. J. Refract. Met. Hard Mater. 2013, 39 , 2-17. [CrossRef]

91. Hassani-Gangaraj, M.; Veysset, D.; Champagne, V.K.; Nelson, K.A.; Schuh, C.A. Adiabatic shear instability is not necessary for adhesion in cold spray. Acta Mater. 2018, 158, 430-439. [CrossRef]

92. Fardan, A.; Berndt, C.C.; Ahmed, R. Numerical modelling of particle impact and residual stresses in cold sprayed coatings: A review. Surf. Coat. Technol. 2021, 409, 126835. [CrossRef]

93. Spencer, K.; Fabijanic, D.M.; Zhang, M.-X. The use of Al-Al2O3 cold spray coatings to improve the surface properties of magnesium alloys. Surf. Coat. Technol. 2009, 204, 336-344. [CrossRef]

94. Yandouzi, M.; Richer, P.; Jodoin, B. SiC Particulate Reinforced Al-12Si Alloy composite coatings produced by the pulsed gas dynamic spray process: Microstructure and properties. Surf. Coat. Technol. 2009, 203, 3260-3270. [CrossRef]

95. De Simone, V.; Caccavo, D.; Lamberti, G.; d'Amore, M.; Barba, A.A. Wet-granulation process: Phenomenological analysis and process parameters optimization. Powder Technol. 2018, 340, 411-419. [CrossRef]

96. Al-Hamdani, K.S.; Murray, J.W.; Hussain, T.; Clare, A.T. Heat-treatment and mechanical properties of cold-sprayed high strength Al alloys from satellited feedstocks. Surf. Coat. Technol. 2019, 374, 21-31. [CrossRef]

97. Woo, D.J.; Heer, F.C.; Brewer, L.N.; Hooper, J.P.; Osswald, S. Synthesis of nanodiamond-reinforced aluminum metal matrix composites using cold-spray deposition. Carbon 2015, 86, 15-25. [CrossRef]

98. Li, W.; Assadi, H.; Gaertner, F.; Yin, S. A review of advanced composite and nanostructured coatings by solid-state cold spraying process. Crit. Rev. Solid State Mater. Sci. 2019, 44, 109-156. [CrossRef]

99. Bakshi, S.R.; Singh, V.; Balani, K.; McCartney, D.G.; Seal, S.; Agarwal, A. Carbon nanotube reinforced aluminum composite coating via cold spraying. Surf. Coat. Technol. 2008, 202, 5162-5169. [CrossRef]

100. Kang, H.-K.; Kang, S.B. Tungsten/copper composite deposits produced by a cold spray. Scr. Mater. 2003, 49, 1169-1174. [CrossRef]

101. Winnicki, M.; Małachowska, A.; Piwowarczyk, T.; Rutkowska-Gorczyca, M.; Ambroziak, A. The bond strength of Al+Al2O3 cermet coatings deposited by low-pressure cold spraying. Arch. Civ. Mech. Eng. 2016, 16, 743-752. [CrossRef]

102. Zhang, L.; Yang, S.; Lv, X.; Jie, X. Wear and corrosion resistance of cold-sprayed Cu-based composite coatings on magnesium substrate. J. Therm. Spray Technol. 2019, 28, 1212-1224. [CrossRef]

103. Koivuluoto, H.; Vuoristo, $\mathrm{P}$. Effect of powder type and composition on structure and mechanical properties of $\mathrm{Cu}+\mathrm{Al}_{2} \mathrm{O}_{3}$ coatings prepared by using low-pressure cold spray process. J. Therm. Spray Technol. 2010, 19, 1081-1092. [CrossRef]

104. Bai, Y.; Wang, Z.; Li, X.; Huang, G.; Li, C.; Li, Y. Microstructure and mechanical properties of Zn-Ni-Al ${ }_{2} \mathrm{O}_{3}$ composite coatings. Materials 2018, 11, 853. [CrossRef]

105. Winnicki, M.; Baszczuk, A.; Rutkowska-Gorczyca, M.; Małachowska, A.; Ambroziak, A. Corrosion resistance of tin coatings deposited by cold spraying. Surf. Eng. 2016, 32, 691-700. [CrossRef]

106. Winnicki, M.; Rutkowska-Gorczyca, M.; Baszczuk, A.; Małachowska, A.; Piwowarczyk, T.; Ambroziak, A. Corrosion resistance of tin coatings deposited by different methods. Acta Phys. Pol. A 2016, 130, 1155-1157. [CrossRef]

107. Winnicki, M.; Łapa, W.; Znamirowski, Z. Field electron emission experiments with cold-sprayed Cu-SiC composite coatings. Coatings 2021, 11, 134. [CrossRef]

108. Li, W.-Y.; Zhang, G.; Liao, H.L.; Coddet, C. Characterizations of cold sprayed TiN particle reinforced Al2319 composite coating. J. Mater. Process. Technol. 2008, 202, 508-513. [CrossRef]

109. Shockley, J.M.; Rauch, E.F.; Chromik, R.R.; Descartes, S. TEM Microanalysis of interfacial structures after dry sliding of cold sprayed Al-Al2O3. Wear 2017, 376-377, 1411-1417. [CrossRef]

110. Qiu, X.; Qi, L.; Tang, J.-R.; Cui, X.-Y.; Du, H.; Wang, J.-Q.; Xiong, T.-Y. Influence of particulate morphology on microstructure and tribological properties of cold sprayed A380/Al2O3 composite coatings. J. Mater. Sci. Technol. 2020, 44, 9-18. [CrossRef]

111. Qiu, X.; Wang, J.Q.; Tang, J.R.; Gyansah, L.; Zhao, Z.P.; Xiong, T.Y. Microstructure, microhardness and tribological behavior of $\mathrm{Al}_{2} \mathrm{O}_{3}$ reinforced $\mathrm{A} 380$ aluminum alloy composite coatings prepared by cold spray technique. Surf. Coat. Technol. 2018, 350, 391-400. [CrossRef]

112. Yang, $\mathrm{K} . ; \mathrm{Li}, \mathrm{W}$.; Xu, Y.; Yang, X. Using friction stir processing to augment corrosion resistance of cold sprayed $\mathrm{AA} 2024 / \mathrm{Al}_{2} \mathrm{O}_{3}$ composite coatings. J. Alloys Compd. 2019, 774, 1223-1232. [CrossRef]

113. Zhang, H.; Yu, M.; Liang, C.; Chen, H. Effect of $\mathrm{SiC}$ deposition behavior on microstructure and mechanical properties of cold-sprayed Al5056/SiC composite coatings. J. Therm. Spray Technol. 2021, 30, 1262-1273. [CrossRef]

114. Ding, R.; Li, X.; Wang, J.; Li, W.; Wang, X.; Gui, T. Antifouling properties and release of dissolved copper of cold spray Cu/Cu $2 \mathrm{O}$ coatings for ships and steel structures in marine environment. J. Mater. Eng. Perform. 2018, 27, 5947-5963. [CrossRef] 
115. Feng, C.; Guipont, V.; Jeandin, M.; Amsellem, O.; Pauchet, F.; Saenger, R.; Bucher, S.; Iacob, C. B4C/Ni composite coatings prepared by cold spray of blended or CVD-coated powders. J. Therm. Spray Technol. 2012, 21, 561-570. [CrossRef]

116. Li, C.-J.; Li, W.-Y.; Wang, Y.-Y.; Yang, G.-J.; Fukanuma, H. A theoretical model for prediction of deposition efficiency in cold spraying. Thin Solid Films 2005, 489, 79-85. [CrossRef]

117. Winnicki, M.; Baszczuk, A.; Rutkowska-Gorczyca, M.; Jasiorski, M.; Małachowska, A.; Posadowski, W.; Znamirowski, Z.; Ambroziak, A. Microscopic examination of cold spray cermet $\mathrm{Sn}+\mathrm{In}_{2} \mathrm{O}_{3}$ coatings for sputtering target materials. Scanning 2017, 2017, e4058636. [CrossRef]

118. Winnicki, M.; Wiatrowski, A.; Mazur, M. High power impulse magnetron sputtering of $\operatorname{In}_{2} \mathrm{O}_{3} /$ Sn cold sprayed composite target. Materials 2021, 14, 1228. [CrossRef]

119. Al-Hamdani, K.S.; Murray, J.W.; Hussain, T.; Kennedy, A.; Clare, A.T. Cold sprayed metal-ceramic coatings using satellited powders. Mater. Lett. 2017, 198, 184-187. [CrossRef]

120. Li, W.-Y.; Zhang, C.; Liao, H.; Li, J.; Coddet, C. Characterizations of cold-sprayed nickel-alumina composite coating with relatively large nickel-coated alumina powder. Surf. Coat. Technol. 2008, 202, 4855-4860. [CrossRef]

121. Okimura, N.; Choi, J.; Nakayama, W.; Ata, N.; Hirata, Y.; Ohtake, N.; Akasaka, H. Metal matrix composites using diamond-like carbon-coated particles fabricated by cold spray technique. J. Therm. Spray Technol. 2020, 29, 1660-1668. [CrossRef]

122. Wang, X.; Zhang, L.; Zhou, X.; Wu, W.; Jie, X. Corrosion behavior of $\mathrm{Al}_{2} \mathrm{O}_{3}$-reinforced graphene encapsulated $\mathrm{Al}$ composite coating fabricated by low pressure cold spraying. Surf. Coat. Technol. 2020, 386, 125486. [CrossRef]

123. Poirier, D.; Legoux, J.-G.; Drew, R.A.L.; Gauvin, R. Consolidation of Al2O3/Al nanocomposite powder by cold spray. J. Therm. Spray Technol. 2011, 20, 275-284. [CrossRef]

124. Huang, J.; Zhang, Y.; Wang, D.; Ren, B.; Song, P.; Zhang, G.; Cai, B.; Liu, Z. Effect of ball milling process on the mechanical and thermal properties of the nanodiamond/2024Al composites. Micron 2021, 148, 103104. [CrossRef] [PubMed]

125. Luo, X.-T.; Yang, G.-J.; Li, C.-J. Preparation of CBNp/NiCrAl nanostructured composite powders by a step-fashion mechanical alloying process. Powder Technol. 2012, 217, 591-598. [CrossRef]

126. Salur, E.; Acarer, M.; Şavkliyildiz, İ. Improving mechanical properties of nano-sized TiC particle reinforced AA7075 Al alloy composites produced by ball milling and hot pressing. Mater. Today Commun. 2021, 27, 102202. [CrossRef]

127. Luo, X.-T.; Li, C.-X.; Shang, F.-L.; Yang, G.-J.; Wang, Y.-Y.; Li, C.-J. WC-Co Composite coating deposited by cold spraying of a core-shell-structured WC-Co powder. J. Therm. Spray Technol. 2014, 24, 100-107. [CrossRef]

128. Li, W.-Y.; Zhang, G.; Zhang, C.; Elkedim, O.; Liao, H.; Coddet, C. Effect of ball milling of feedstock powder on microstructure and properties of TiN particle-reinforced Al alloy-based composites fabricated by cold spraying. J. Therm. Spray Technol. 2008, 17, 316-322. [CrossRef]

129. Chen, H.; Pala, Z.; Hussain, T.; McCartney, D.G. Fabrication and microstrain evolution of Al-TiB 2 composite coating by cold spray deposition. Proc. Inst. Mech. Eng. Part. J. Mater. Des. Appl. 2017, 233, 1044-1052. [CrossRef]

130. Yandouzi, M.; Bu, H.; Brochu, M.; Jodoin, B. Nanostructured Al-based metal matrix composite coating production by pulsed gas dynamic spraying process. J. Therm. Spray Technol. 2012, 21, 609-619. [CrossRef]

131. Kim, J.S.; Kwon, Y.S.; Lomovsky, O.I.; Dudina, D.V.; Kosarev, V.F.; Klinkov, S.V.; Kwon, D.H.; Smurov, I. Cold spraying of in situ produced TiB2-Cu nanocomposite powders. Compos. Sci. Technol. 2007, 67, 2292-2296. [CrossRef]

132. Neri, G.; Bonavita, A.; Micali, G.; Rizzo, G.; Licheri, R.; Orrù, R.; Cao, G. Resistive $\lambda$-sensors based on ball milled Fe-doped SrTiO3 nanopowders obtained by self-propagating high-temperature synthesis (SHS). Sens. Actuators B Chem. 2007, 1, 258-265. [CrossRef]

133. Vasanthakumar, K.; Gorle, R.; Ariharan, S.; Bakshi, S.R. Novel single phase $\left(\mathrm{Ti}_{0.2} \mathrm{~W}_{0.2} \mathrm{Ta}_{0.2} \mathrm{Mo}_{0.2} \mathrm{~V}_{0.2}\right) \mathrm{C}_{0.8}$ High entropy carbide using ball milling followed by reactive spark plasma sintering. J. Eur. Ceram. Soc. 2021. [CrossRef]

134. Bian, H.; Yang, Y.; Wang, Y.; Tian, W. Preparation of nanostructured alumina-titania composite powders by spray drying, heat treatment and plasma treatment. Powder Technol. 2012, 219, 257-263. [CrossRef]

135. Kim, H.-J.; Lee, C.-H.; Hwang, S.-Y. Superhard nano WC-12\%Co coating by cold spray deposition. Mater. Sci. Eng. A 2005, 391, 243-248. [CrossRef]

136. Dosta, S.; Couto, M.; Guilemany, J.M. Cold spray deposition of a WC-25Co cermet onto Al7075-T6 and carbon steel substrates. Acta Mater. 2013, 61, 643-652. [CrossRef]

137. Gao, P.-H.; Li, C.-J.; Yang, G.-J.; Li, Y.-G.; Li, C.-X. Influence of substrate hardness transition on built-up of nanostructured WC-12Co by cold spraying. Appl. Surf. Sci. 2010, 256, 2263-2268. [CrossRef]

138. Bakshi, S.R.; Singh, V.; Seal, S.; Agarwal, A. Aluminum composite reinforced with multiwalled carbon nanotubes from plasma spraying of spray dried powders. Surf. Coat. Technol. 2009, 203, 1544-1554. [CrossRef]

139. Winnicki, M.; Małachowska, A.; Ambroziak, A. Taguchi optimization of the thickness of a coating deposited by LPCS. Arch. Civ. Mech. Eng. 2014, 14, 561-568. [CrossRef]

140. Zhang, Z.; Liu, F.; Han, E.-H.; Xu, L.; Uzoma, P.C. Effects of $\mathrm{Al}_{2} \mathrm{O}_{3}$ on the microstructures and corrosion behavior of low-pressure cold gas sprayed Al 2024-Al2O3 composite coatings on AA 2024-T3 substrate. Surf. Coat. Technol. 2019, 370, 53-68. [CrossRef]

141. Wang, Q.; Spencer, K.; Birbilis, N.; Zhang, M.-X. The influence of ceramic particles on bond strength of cold spray composite coatings on AZ91 alloy substrate. Surf. Coat. Technol. 2010, 205, 50-56. [CrossRef]

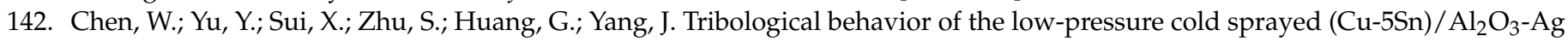
solid-lubricating coating in artificial seawater. Surf. Coat. Technol. 2020, 403, 126359. [CrossRef] 
143. Chen, W.; Yu, Y.; Tieu, A.K.; Hao, J.; Wang, L.; Zhu, S.; Yang, J. Microstructure, mechanical properties and tribological behavior of the low-pressure cold sprayed tin bronze-alumina coating in artificial seawater. Tribol. Int. 2020, 142, 105992. [CrossRef]

144. Koivuluoto, H.; Lagerbom, J.; Kylmälahti, M.; Vuoristo, P. Microstructure and mechanical properties of low-pressure cold-sprayed (LPCS) coatings. J. Therm. Spray Technol. 2008, 17, 721-727. [CrossRef]

145. Koivuluoto, H.; Coleman, A.; Murray, K.; Kearns, M.; Vuoristo, P. High pressure cold sprayed (HPCS) and low pressure cold sprayed (LPCS) coatings prepared from OFHC Cu feedstock: Overview from powder characteristics to coating properties. J. Therm. Spray Technol. 2012, 21, 1065-1075. [CrossRef]

146. Lee, Y.T.R.; Ashrafizadeh, H.; Fisher, G.; McDonald, A. Effect of type of reinforcing particles on the deposition efficiency and wear resistance of low-pressure cold-sprayed metal matrix composite coatings. Surf. Coat. Technol. 2017, 324, 190-200. [CrossRef]

147. Melendez, N.M.; Narulkar, V.V.; Fisher, G.A.; McDonald, A.G. Effect of reinforcing particles on the wear rate of low-pressure cold-sprayed WC-based MMC coatings. Wear 2013, 306, 185-195. [CrossRef]

148. Nunthavarawong, P.; Sacks, N.; Botef, I. Effect of powder feed rate on the mechanical properties of WC-5wt\%Ni coatings deposited using low pressure cold spray. Int. J. Refract. Met. Hard Mater. 2016, 61, 230-237. [CrossRef]

149. Sacks, N. Low pressure cold gas dynamic spraying of tungsten carbide-nickel coatings. Met. Powder Rep. 2016, 71, 356-358. [CrossRef]

150. Wang, H.-T.; Li, C.-J.; Yang, G.-J.; Li, C.-X. Cold spraying of Fe/Al powder mixture: Coating characteristics and influence of heat treatment on the phase structure. Appl. Surf. Sci. 2008, 255, 2538-2544. [CrossRef]

151. Shen, L.; Kong, L.; Xiong, T.; Du, H.; Li, T. Preparation of TiAl3-Al composite coating by cold spraying. Trans. Nonferrous Met. Soc. China 2009, 19, 879-882. [CrossRef]

152. Bai, Y.; Wang, Z.H.; Li, X.B.; Huang, G.S.; Li, C.X.; Li, Y. Corrosion behavior of low pressure cold sprayed Zn-Ni composite coatings. J. Alloys Compd. 2017, 719, 194-202. [CrossRef]

153. Winnicki, M.; Jasiorski, M.; Baszczuk, A.; Korzeniowski, M. Heat-treatment of aluminium-nickel composite cold sprayed coating. Coatings 2020, 10, 581. [CrossRef]

154. Adebiyi, D.I.; Popoola, A.P.I.; Botef, I. Low pressure cold spray coating of Ti-6Al-4V with SiC-based cermet. Mater. Lett. 2016, 175, 63-67. [CrossRef]

155. Zhang, L.W.; Ning, X.J.; Lu, L.; Wang, Q.S.; Wang, L. Hot corrosion behavior of low-pressure cold-sprayed CoNiCrAlY coatings. J. Therm. Spray Technol. 2016, 25, 587-594. [CrossRef]

156. Kılıçay, K. Development of Protective MMC Coating on TZM Alloy for high temperature oxidation resistance by LPCS. Surf. Coat. Technol. 2020, 393, 125777. [CrossRef]

157. Kumar, S.; Reddy, S.K.; Joshi, S.V. Microstructure and performance of cold sprayed Al-SiC composite coatings with high fraction of particulates. Surf. Coat. Technol. 2017, 318, 62-71. [CrossRef]

158. Peat, T.; Galloway, A.; Toumpis, A.; McNutt, P.; Iqbal, N. The erosion performance of particle reinforced metal matrix composite coatings produced by co-deposition cold gas dynamic spraying. Appl. Surf. Sci. 2017, 396, 1623-1634. [CrossRef]

159. Chen, W.; Yu, Y.; Ma, J.; Zhu, S.; Liu, W.; Yang, J. Low-pressure cold spraying of copper-graphite solid lubricating coatings on aluminum alloy 7075-T651. J. Therm. Spray Technol. 2019, 28, 1688-1698. [CrossRef]

160. Winnicki, M.; Małachowska, A.; Korzeniowski, M.; Jasiorski, M.; Baszczuk, A. Aluminium to steel resistance spot welding with cold sprayed interlayer. Surf. Eng. 2018, 34, 235-242. [CrossRef]

161. Wojdat, T.; Winnicki, M.; Łamasz, S.; Żuk, A. Application of interlayers in the soldering process of graphite composite to aluminium alloy 6060. Arch. Civ. Mech. Eng. 2019, 19, 91-99. [CrossRef]

162. Wang, Y.; Normand, B.; Mary, N.; Yu, M.; Liao, H. Microstructure and corrosion behavior of cold sprayed SiCp/Al 5056 composite coatings. Surf. Coat. Technol. 2014, 251, 264-275. [CrossRef]

163. Dzhurinskiy, D.; Maeva, E.; Leshchinsky, E.; Maev, R.G. Corrosion protection of light alloys using low pressure cold spray. J. Therm. Spray Technol. 2012, 21, 304-313. [CrossRef]

164. Bala, N.; Singh, H.; Prakash, S. High temperature corrosion behavior of cold spray Ni-20Cr coating on boiler steel in molten salt environment at $900^{\circ} \mathrm{C}$. J. Therm. Spray Technol. 2010, 19, 110-118. [CrossRef]

165. Singh, H.; Sidhu, T.S.; Kalsi, S.B.S.; Karthikeyan, J. Hot Corrosion behavior of cold-sprayed Ni-50Cr coating in an incinerator environment at $900{ }^{\circ} \mathrm{C}$. J. Therm. Spray Technol. 2015, 24, 570-578. [CrossRef]

166. Singh, H.; Sidhu, T.S.; Karthikeyan, J.; Kalsi, S.B.S. Evaluation of characteristics and behavior of cold sprayed Ni-20Cr coating at elevated temperature in waste incinerator plant. Surf. Coat. Technol. 2015, 261, 375-384. [CrossRef]

167. Li, L.; Shang, Z.; Xiao, Z.; Wang, L.; Liang, X.; Liu, G. Steam reforming of N-Dodecane over mesoporous alumina supported nickel catalysts: Effects of metal-support interaction on nickel catalysts. Int. J. Hydrog. Energy 2019, 44, 6965-6977. [CrossRef]

168. da SQ Menezes, J.P.; Dias, A.P.D.S.; da Silva, M.A.; Souza, M.M. Effect of alkaline earth oxides on nickel catalysts supported over $\gamma$-alumina for butanol steam reforming: Coke formation and deactivation process. Int. J. Hydrog. Energy 2020, 45, 22906-22920. [CrossRef]

169. Ling, H.J.; Mai, Y.J.; Li, S.L.; Zhang, L.Y.; Liu, C.S.; Jie, X.H. Microstructure and improved tribological performance of graphite/copper-zinc composite coatings fabricated by low pressure cold spraying. Surf. Coat. Technol. 2019, 364, $256-264$. [CrossRef] 
170. Chen, W.; Yu, Y.; Cheng, J.; Wang, S.; Zhu, S.; Liu, W.; Yang, J. Microstructure, mechanical properties and dry sliding wear behavior of $\mathrm{Cu}-\mathrm{Al} 2 \mathrm{O} 3$-graphite solid-lubricating coatings deposited by low-pressure cold spraying. J. Therm. Spray Technol. 2018, 27, 1652-1663. [CrossRef]

171. Mathers, G. The Welding of Aluminium and Its Alloys, 1st ed.; Mathers, G., Ed.; Woodhead Publishing: Cornwall, UK, 2002.

172. Martinsen, K.; Hu, S.J.; Carlson, B.E. Joining of Dissimilar Materials. CIRP Ann. 2015, 64, 679-699. [CrossRef]

173. Dong, K.; Kong, J.; Peng, Y.; Zhou, Q.; Wang, K. A new strategy for high-strength joining of dissimilar materials. J. Mater. Process. Technol. 2020, 283, 116724. [CrossRef]

174. Liyanage, T.; Kilbourne, J.; Gerlich, A.P.; North, T.H. Joint formation in dissimilar Al alloy/steel and Mg alloy/steel friction stir spot welds. Sci. Technol. Weld. Join. 2009, 14, 500-508. [CrossRef]

175. Evans, W.T.; Gibson, B.T.; Reynolds, J.T.; Strauss, A.M.; Cook, G.E. Friction stir extrusion: A new process for joining dissimilar materials. Manuf. Lett. 2015, 5, 25-28. [CrossRef]

176. Qiu, R.; Shi, H.; Zhang, K.; Tu, Y.; Iwamoto, C.; Satonaka, S. Interfacial characterization of joint between mild steel and aluminum alloy welded by resistance spot welding. Mater. Charact. 2010, 61, 684-688. [CrossRef]

177. Ibrahim, I.; Ito, R.; Kakiuchi, T.; Uematsu, Y.; Yun, K.; Matsuda, C. Fatigue behaviour of Al/steel dissimilar resistance spot welds fabricated using Al-Mg interlayer. Sci. Technol. Weld. Join. 2016, 21, 223-233. [CrossRef]

178. Penner, P.; Liu, L.; Gerlich, A.; Zhou, Y. Feasibility study of resistance spot welding of dissimilar Al/Mg combinations with Ni based interlayers. Sci. Technol. Weld. Join. 2013, 18, 541-550. [CrossRef]

179. Feng, Y.; Li, Y.; Luo, Z.; Ling, Z.; Wang, Z. Resistance spot welding of Mg to electro-galvanized steel with hot-dip galvanized steel interlayer. J. Mater. Process. Technol. 2016, 236, 114-122. [CrossRef]

180. Manladan, S.M.; Yusof, F.; Ramesh, S.; Fadzil, M. A review on resistance spot welding of magnesium alloys. Int. J. Adv. Manuf. Technol. 2016, 86, 1805-1825. [CrossRef]

181. Manladan, S.M.; Yusof, F.; Ramesh, S.; Fadzil, M.; Luo, Z.; Ao, S. A review on resistance spot welding of aluminum alloys. Int. J. Adv. Manuf. Technol. 2017, 90, 605-634. [CrossRef]

182. Wojdat, T.; Winnicki, M.; Rutkowska-Gorczyca, M.; Krupiński, S.; Kubica, K. Soldering aluminium to copper with the use of interlayers deposited by cold spraying. Arch. Civ. Mech. Eng. 2016, 16, 835-844. [CrossRef]

183. Li, J.F.; Agyakwa, P.A.; Johnson, C.M.; Zhang, D.; Hussain, T.; McCartney, D.G. Characterization and solderability of cold sprayed Sn-Cu coatings on Al and Cu substrates. Surf. Coat. Technol. 2010, 204, 1395-1404. [CrossRef]

184. Hou, W.; Shen, Z.; Huda, N.; Oheil, M.; Shen, Y.; Jahed, H.; Gerlich, A.P. Enhancing metallurgical and mechanical properties of friction stir butt welded joints of Al-Cu via cold sprayed Ni interlayer. Mater. Sci. Eng. A 2021, 809, 140992. [CrossRef]

185. Hou, W.; Oheil, M.; Shen, Z.; Shen, Y.; Jahed, H.; Gerlich, A. Enhanced strength and ductility in dissimilar friction stir butt welded $\mathrm{Al} / \mathrm{Cu}$ joints by addition of a cold-spray Ni interlayer. J. Manuf. Process. 2020, 60, 573-577. [CrossRef]

186. Wang, H.; Xu, X.; Li, X.; Zhang, J.; Li, C. Synthesis and sintering of indium tin oxide nanoparticles by citrate-nitrate combustion method. Rare Met. 2010, 29, 355-360. [CrossRef]

187. Xu, J.; Yang, L.; Wang, H.; Zhu, G.; Xu, H.; Zhou, C.; Yuan, C.; Yang, Z. Sintering behavior and refining grains of high density tin doped indium oxide targets with low tin oxide content. J. Mater. Sci. Mater. Electron. 2016, 27, 3298-3304. [CrossRef]

188. Kumar, M.; Singh, H.; Singh, N. Effect of increase in nano-particle addition on mechanical and microstructural behaviour of HVOF and cold-spray Ni-20Cr coatings on boiler steels. Mater. Today Proc. 2020, 21, 2035-2042. [CrossRef]

189. Lupoi, R.; Sparkes, M.; Cockburn, A.; O’Neill, W. High speed titanium coatings by supersonic laser deposition. Mater. Lett. 2011, 65, 3205-3207. [CrossRef]

190. Barton, D.J.; Bhattiprolu, V.S.; Thompson, G.B.; Brewer, L.N. Laser assisted cold spray of AISI 4340 steel. Surf. Coat. Technol. 2020, 400, 126218. [CrossRef]

191. Stutzman, A.M.; Rai, A.K.; Alexandreanu, B.; Albert, P.E.; Sun, E.J.; Schwartz, M.L.; Reutzel, E.W.; Tressler, J.F.; Medill, T.P.; Wolfe, D.E. Laser glazing of cold sprayed coatings for the mitigation of stress corrosion cracking in light water reactor (LWR) applications. Surf. Coat. Technol. 2020, 386, 125429. [CrossRef]

192. Olakanmi, E.O.; Doyoyo, M. Laser-assisted cold-sprayed corrosion- and wear-resistant coatings: A review. J. Therm. Spray Technol. 2014, 23, 765-785. [CrossRef]

193. Wang, W.; Han, P.; Wang, Y.; Zhang, T.; Peng, P.; Qiao, K.; Wang, Z.; Liu, Z.; Wang, K. High-performance bulk pure Al prepared through cold spray-friction stir processing composite additive manufacturing. J. Mater. Res. Technol. 2020, 9, 9073-9079. [CrossRef]

194. Li, W.; Wu, D.; Hu, K.; Xu, Y.; Yang, X.; Zhang, Y. A comparative study on the employment of heat treatment, electric pulse processing and friction stir processing to enhance mechanical properties of cold-spray-additive-manufactured copper. Surf. Coat. Technol. 2021, 409, 126887. [CrossRef]

195. Hoziefa, W.; Toschi, S.; Ahmed, M.M.Z.; Morri, A.; Mahdy, A.A.; El-Sayed Seleman, M.M.; El-Mahallawi, I.; Ceschini, L.; Atlam, A. Influence of friction stir processing on the microstructure and mechanical properties of a compocast $\mathrm{AA}^{2024-\mathrm{Al}_{2} \mathrm{O}_{3}}$ nanocomposite. Mater. Des. 2016, 106, 273-284. [CrossRef]

196. Khodabakhshi, F.; Gerlich, A.P.; Švec, P. Fabrication of a high strength ultra-fine grained Al-Mg-SiC nanocomposite by multi-step friction-stir processing. Mater. Sci. Eng. A 2017, 698, 313-325. [CrossRef]

197. Khodabakhshi, F.; Simchi, A.; Kokabi, A.H. Surface modifications of an aluminum-magnesium alloy through reactive stir friction processing with titanium oxide nanoparticles for enhanced sliding wear resistance. Surf. Coat. Technol. 2017, 309, 114-123. [CrossRef] 
198. Hodder, K.J.; Izadi, H.; McDonald, A.G.; Gerlich, A.P. Fabrication of aluminum-alumina metal matrix composites via cold gas dynamic spraying at low pressure followed by friction stir processing. Mater. Sci. Eng. A 2012, 556, 114-121. [CrossRef]

199. Khodabakhshi, F.; Marzbanrad, B.; Yazdanmehr, A.; Jahed, H.; Gerlich, A.P. Tailoring the residual stress during two-step cold gas spraying and friction-stir surface integration of titanium coating. Surf. Coat. Technol. 2019, 380, 125008. [CrossRef]

200. Khodabakhshi, F.; Marzbanrad, B.; Jahed, H.; Gerlich, A.P. Interfacial bonding mechanisms between aluminum and titanium during cold gas spraying followed by friction-stir modification. Appl. Surf. Sci. 2018, 462, 739-752. [CrossRef]

201. Shackelford, J.F.; Doremus, R.H. Ceramic and Glass Materials: Structure, Properties and Processing, 1st ed.; Springer: New York, NY, USA, 2008.

202. Asmatulu, R. Nanocoatings for corrosion protection of aerospace alloys. In Corrosion Protection and Control Using Nanomaterials; Saji, V.S., Cook, R., Eds.; Woodhead Publishing Series in Metals and Surface Engineering; Woodhead Publishing: Cambridge, UK, 2012; pp. 357-374.

203. Tejero-Martin, D.; Rezvani Rad, M.; McDonald, A.; Hussain, T. Beyond traditional coatings: A review on thermal-sprayed functional and smart coatings. J. Therm. Spray Technol. 2019, 28, 598-644. [CrossRef]

204. Bolelli, G.; Cannillo, V.; Lusvarghi, L.; Manfredini, T. Wear behaviour of thermally sprayed ceramic oxide coatings. Wear 2006, 261, 1298-1315. [CrossRef]

205. Zavareh, M.A.; Sarhan, A.A.D.M.; Razak, B.B.A.; Basirun, W.J. Plasma thermal spray of ceramic oxide coating on carbon steel with enhanced wear and corrosion resistance for oil and gas applications. Ceram. Int. 2014, 40, 14267-14277. [CrossRef]

206. Monticelli, C.; Balbo, A.; Zucchi, F. Corrosion and tribocorrosion behaviour of thermally sprayed ceramic coatings on steel. Surf. Coat. Technol. 2011, 205, 3683-3691. [CrossRef]

207. Guo, S.; Xu, D.; Liang, Y.; Gong, Y.; Li, Y.; Yang, J. Corrosion characterization of $\mathrm{ZrO}_{2}$ and $\mathrm{TiO}_{2}$ ceramic coatings via air plasma spraying on 316 stainless steel in oxygenated sub- and supercritical water. J. Supercrit. Fluids 2020, 157, 104716. [CrossRef]

208. Baskaran, T.; Arya, S.B. Hot corrosion resistance of air plasma sprayed ceramic $\mathrm{Sm}_{2} \mathrm{SrAl}_{2} \mathrm{O}_{7}$ (SSA) thermal barrier coatings in simulated gas turbine environments. Ceram. Int. 2018, 44, 17695-17708. [CrossRef]

209. Wang, Y.; Han, Y.; Lin, C.; Zheng, W.; Jiang, C.; Wei, A.; Liu, Y.; Zeng, Y.; Shi, Y. Effect of spraying power on the morphology of YSZ splat and micro-structure of thermal barrier coating. Ceram. Int. 2021, 47, 18956-18963. [CrossRef]

210. Guski, V.; Verestek, W.; Rapp, D.; Schmauder, S. Microstructural investigation of plasma sprayed ceramic coatings focusing on the effect of the splat boundary for SOFC sealing applications using peridynamics. Theor. Appl. Fract. Mech. 2021, 112, 102926. [CrossRef]

211. Łatka, L.; Michalak, M.; Szala, M.; Walczak, M.; Sokołowski, P.; Ambroziak, A. Influence of 13 Wt\% TiO2 Content in aluminatitania powders on microstructure, sliding wear and cavitation erosion resistance of APS sprayed coatings. Surf. Coat. Technol. 2021, 410, 126979. [CrossRef]

212. Kiilakoski, J.; Langlade, C.; Koivuluoto, H.; Vuoristo, P. Characterizing the micro-impact fatigue behavior of APS and HVOFsprayed ceramic coatings. Surf. Coat. Technol. 2019, 371, 245-254. [CrossRef]

213. Bordes, M.C.; Vicent, M.; Moreno, A.; Moreno, R.; Borrell, A.; Salvador, M.D.; Sanchez, E. Microstructure and photocatalytic activity of APS coatings obtained from different $\mathrm{TiO}_{2}$ nanopowders. Surf. Coat. Technol. 2013, 220, 179-186. [CrossRef]

214. Bolelli, G.; Lusvarghi, L.; Varis, T.; Turunen, E.; Leoni, M.; Scardi, P.; Azanza-Ricardo, C.L.; Barletta, M. Residual stresses in HVOF-sprayed ceramic coatings. Surf. Coat. Technol. 2008, 202, 4810-4819. [CrossRef]

215. Liu, Z.; Wang, H.; Haché, M.J.R.; Chu, X.; Irissou, E.; Zou, Y. Prediction of heterogeneous microstructural evolution in cold sprayed copper coatings using local zener-hollomon parameter and strain. Acta Mater. 2020, 193, 191-201. [CrossRef]

216. Assadi, H.; Gärtner, F.; Stoltenhoff, T.; Kreye, H. Bonding mechanism in cold gas spraying. Acta Mater. 2003, 51, 4379-4394. [CrossRef]

217. Sarobol, P.; Chandross, M.; Carroll, J.D.; Mook, W.M.; Bufford, D.C.; Boyce, B.L.; Hattar, K.; Kotula, P.G.; Hall, A.C. Room temperature deformation mechanisms of alumina particles observed from in situ micro-compression and atomistic simulations. $J$. Therm. Spray Technol. 2016, 25, 82-93. [CrossRef]

218. Palmero, P. Synthesis of Ceramic Powders by Wet Chemical Routes. In Encyclopedia of Materials: Technical Ceramics and Glasses; Pomeroy, M., Ed.; Elsevier: Oxford, UK, 2021; pp. 27-39.

219. Shin, H.; Lee, S.; Suk Jung, H.; Kim, J.-B. Effect of ball size and powder loading on the milling efficiency of a laboratory-scale wet ball mill. Ceram. Int. 2013, 39, 8963-8968. [CrossRef]

220. Saghir, M.; Umer, M.A.; Ahmed, A.; Monir, N.B.; Manzoor, U.; Razzaq, A.; Xian, L.; Mohammad, K.; Shahid, M.; Park, Y.-K. Effect of high energy ball milling and low temperature densification of plate-like alumina powder. Powder Technol. 2021, 383, 84-92. [CrossRef]

221. Xu, D.; Tang, D.; Jiao, L.; Yuan, H.; Zhao, G.; Cheng, X. Effects of high-energy ball milling oxide-doped and varistor ceramic powder on ZnO varistor. Trans. Nonferrous Met. Soc. China 2012, 22, 1423-1431. [CrossRef]

222. Turon-Vinas, M.; Zhang, F.; Vleugels, J.; Anglada, M. Effect of calcia Co-doping on ceria-stabilized zirconia. J. Eur. Ceram. Soc. 2018, 38, 2621-2631. [CrossRef]

223. Liu, J.-A.; Li, C.-H.; Zou, Y.; Chen, A.-N.; Hu, L.; Shi, Y.-S. Effect of ball milling on the sintering performance of indium-galliumzinc oxide ceramics: The diffusion mechanism and lattice distortion of milled powders. Ceram. Int. 2021, 47, 15682-15694. [CrossRef] 
224. Wangle, T.; Tyrpekl, V.; Delloye, T.; Larcher, O.; Pakarinen, J.; Cardinaels, T.; Vleugels, J.; Verwerft, M. Homogeneous hydrolysis of thorium by thermal decomposition of urea. Radiochim. Acta 2018, 106, 645-653. [CrossRef]

225. Zhang, J.-Y.; Luo, Z.-H.; Jiang, H.-C.; Jiang, J.; Chen, C.-H.; Zhang, J.-X.; Gui, Z.-Z.; Xiao, N. Highly transparent cerium doped gadolinium gallium aluminum garnet ceramic prepared with precursors fabricated by ultrasonic enhanced chemical co-precipitation. Ultrason. Sonochem. 2017, 39, 792-797. [CrossRef] [PubMed]

226. Kravtsov, A.A.; Chikulina, I.S.; Tarala, V.A.; Evtushenko, E.A.; Shama, M.S.; Tarala, L.V.; Malyavin, F.F.; Vakalov, D.S.; Lapin, V.A.; Kuleshov, D.S. Novel synthesis of low-agglomerated YAG:Yb ceramic nanopowders by two-stage precipitation with the use of hexamine. Ceram. Int. 2019, 45, 1273-1282. [CrossRef]

227. Li, J.; Han, X.; Wu, L.; Sun, X.; Qi, X. Photoluminescence properties of ( $\mathrm{Y} 1-\mathrm{xCex})_{3} \mathrm{Al}_{5} \mathrm{O}_{12}(\mathrm{X}=0.005-0.03)$ nanophosphors and transparent ceramic by a homogeneous co-precipitation method. J. Lumin. 2019, 206, 364-369. [CrossRef]

228. Chen, X.; Chao, X.; Yang, Z. Submicron Barium calcium zirconium titanate ceramic for energy storage synthesised via the Co-precipitation method. Mater. Res. Bull. 2019, 111, 259-266. [CrossRef]

229. Stunda-Zujeva, A.; Irbe, Z.; Berzina-Cimdina, L. Controlling the morphology of ceramic and composite powders obtained via spray drying-A review. Ceram. Int. 2017, 43, 11543-11551. [CrossRef]

230. Kim, D.-J.; Jung, J.-Y. Granule performance of zirconia/alumina composite powders spray-dried using polyvinyl pyrrolidone binder. J. Eur. Ceram. Soc. 2007, 27, 3177-3182. [CrossRef]

231. Wang, A.; Lu, Y.; Zhu, R.; Li, S.; Ma, X. Effect of process parameters on the performance of spray dried hydroxyapatite microspheres. Powder Technol. 2009, 191, 1-6. [CrossRef]

232. Bertrand, G.; Roy, P.; Filiatre, C.; Coddet, C. Spray-dried ceramic powders: A quantitative correlation between slurry characteristics and shapes of the granules. Chem. Eng. Sci. 2005, 60, 95-102. [CrossRef]

233. Vicent, M.; Sánchez, E.; Moreno, A.; Moreno, R. Preparation of high solids content nano-titania suspensions to obtain spray-dried nanostructured powders for atmospheric plasma spraying. J. Eur. Ceram. Soc. 2012, 32, 185-194. [CrossRef]

234. Chahal, H.K.; Matthews, S.; Jones, M.I. Effect of process conditions on spray dried calcium carbonate powders for thermal spraying. Ceram. Int. 2021, 47, 351-360. [CrossRef]

235. Dave, B.C.; Lockwood, S.B. Sol-Gel Method. In Encyclopedia of Nanotechnology; Bhushan, B., Ed.; Springer: Dordrecht, The Netherlands, 2016; pp. 3748-3761.

236. Mastoroudes, B.C.; Markgraaff, J.; Wagener, J.B.; Olivier, E.J. Synthesis of cesium, sodium and nitrogen derived titanates using the pechini sol-gel method. Chem. Phys. 2020, 537, 110816. [CrossRef]

237. Ehi-Eromosele, C.O.; Ajayi, S.O.; Onwucha, C.N. Influence of fuels in the sol-gel combustion synthesis of $\mathrm{Li}_{2} \mathrm{MnO}_{3}$ positive electrode material for Li-Ion battery. Mater. Chem. Phys. 2021, 259, 124055. [CrossRef]

238. Tan, S.N.; Wang, W.; Ge, L. 3.30 Biosensors Based on Sol-Gel Derived Materials*. In Comprehensive Biomaterials II; Ducheyne, P., Ed.; Elsevier: Oxford, UK, 2017; pp. 657-689.

239. Trindade, F.; Politi, M.J. Sol-gel chemistry-Deals with sol-gel processes. In Nano Design for Smart Gels; Bacani, R., Trindade, F., Politi, M.J., Triboni, E.R., Eds.; Micro and Nano Technologies; Elsevier: Amsterdam, The Netherlands, 2019; pp. 15-34.

240. Winnicki, M.; Baszczuk, A.; Jasiorski, M.; Borak, B.; Małachowska, A. Preliminary studies of TiO2 nanopowder deposition onto metallic substrate by low pressure cold spraying. Surf. Coat. Technol. 2019, 371, 194-202. [CrossRef]

241. Baszczuk, A.; Jasiorski, M.; Winnicki, M. Low-temperature transformation of amorphous sol-gel TiO2 powder to anatase during cold spray deposition. J. Therm. Spray Technol. 2018, 27, 1551-1562. [CrossRef]

242. Gibas, A.; Baszczuk, A.; Jasiorski, M.; Winnicki, M. Prospects of low-pressure cold spray for superhydrophobic coatings. Coatings 2019, 9, 829. [CrossRef]

243. Feng, Q.; Ma, X.H.; Yan, Q.Z.; Ge, C.C. Preparation of soft-agglomerated nano-sized ceramic powders by sol-gel combustion process. Mater. Sci. Eng. B 2009, 162, 53-58. [CrossRef]

244. Davar, F.; Shayan, N. Preparation of zirconia-magnesia nanocomposite powders and coating by a sucrose mediated sol-gel method and investigation of its corrosion behavior. Ceram. Int. 2017, 43, 3384-3392. [CrossRef]

245. Zhang, X.; Li, P.; Guo, Y.; Yang, X.; Yan, T.; Guo, X.; Li, F. Preparation of alumina ultrafine powders through acrylamide, starch and glutaric dialdehyde mediated sol-gel method. Ceram. Int. 2016, 42, 6587-6594. [CrossRef]

246. Naderi-beni, B.; Alizadeh, A. Preparation of single phase AlON powders aided by the nitridation of sol-gel-derived nanoparticles. Ceram. Int. 2019, 45, 7537-7543. [CrossRef]

247. Yu, Y.-H.; Xia, M. Preparation and characterization of $\mathrm{ZnTiO}_{3}$ powders by sol-gel process. Mater. Lett. 2012, 77, 10-12. [CrossRef]

248. Lin, G.-S.; Liu, Y.-C.; Anbarasan, R.; Nakagawa, K.; Yoshioka, T.; Matsuyama, H.; Tseng, H.-H.; Tung, K.-L. Silica gel-coated silicon carbide layer deposited by atmospheric plasma spraying. J. Taiwan Inst. Chem. Eng. 2020, 110, 173-181. [CrossRef]

249. Gowtham Sanjai, S.; Srideep, S.; Anantha Krishna, B.; Sai Sumanth, M.; Ramaswamy, P. Synthesis of yttria-stabilized zirconia nano powders for plasma sprayed nano coatings. Mater. Today Proc. 2020, 22, 1253-1263. [CrossRef]

250. Joshi, S.V.; Srivastava, M.P.; Chatterjee, M.; Ray, J.; Chatterjee, A.; Ganguli, D. Plasma spraying of an indigenous yttria stabilized zirconia powder prepared by the sol-gel technique. Bull. Mater. Sci. 1993, 16, 19-28. [CrossRef]

251. Winnicki, M.; Łatka, L.; Jasiorski, M.; Baszczuk, A. Mechanical properties of $\mathrm{TiO}_{2}$ coatings deposited by low pressure cold spraying. Surf. Coat. Technol. 2021, 405, 126516. [CrossRef]

252. Yang, G.-J.; Li, C.-J.; Han, F.; Li, W.-Y.; Ohmori, A. Low temperature deposition and characterization of TiO 2 photocatalytic film through cold spray. Appl. Surf. Sci. 2008, 254, 3979-3982. [CrossRef] 
253. Salim, N.T.; Yamada, M.; Nakano, H.; Shima, K.; Isago, H.; Fukumoto, M. The effect of post-treatments on the powder morphology of titanium dioxide $\left(\mathrm{TiO}_{2}\right)$ powders synthesized for cold spray. Surf. Coat. Technol. 2011, 206, 366-371. [CrossRef]

254. Toibah, A.R.; Sato, M.; Yamada, M.; Fukumoto, M. Cold-sprayed $\mathrm{TiO}_{2}$ coatings from nanostructured ceramic agglomerated powders. Mater. Manuf. Process. 2016, 31, 1527-1534. [CrossRef]

255. Vilardell, A.M.; Cinca, N.; Cano, I.G.; Concustell, A.; Dosta, S.; Guilemany, J.M.; Estradé, S.; Ruiz-Caridad, A.; Peiró, F. Dense Nanostructured calcium phosphate coating on titanium by cold spray. J. Eur. Ceram. Soc. 2017, 37, 1747-1755. [CrossRef]

256. Cinca, N.; Vilardell, A.M.; Dosta, S.; Concustell, A.; Cano, I.G.; Guilemany, J.M.; Estradé, S.; Ruiz, A.; Peiró, F. A new alternative for obtaining nanocrystalline bioactive coatings: Study of hydroxyapatite deposition mechanisms by cold gas spraying. J. Am. Ceram. Soc. 2016, 99, 1420-1428. [CrossRef]

257. Laohaprapanon, S.; Vanderlipe, A.D.; Doma, B.T., Jr.; You, S.-J. Self-cleaning and antifouling properties of plasma-grafted poly(vinylidene fluoride) membrane coated with $\mathrm{ZnO}$ for water treatment. J. Taiwan Inst. Chem. Eng. 2017, 70, 15-22. [CrossRef]

258. Liu, Y.; Li, H.; Zhang, B.T. Nanostructured Ceramic Coating Biomaterials. In Advanced Nanomaterials and Coatings by Thermal Spray; Yang, G.-J., Suo, X., Eds.; Micro and Nano Technologies; Elsevier: Amsterdam, The Netherlands, 2019 ; pp. $291-311$.

259. Yilmaz, O.; Yorgancioglu, A. Nanocoatings: Preparation, Properties, and Biomedical Applications. In Polymeric Nanomaterials in Nanotherapeutics; Vasile, C., Ed.; Micro and Nano Technologies; Elsevier: Amsterdam, The Netherlands, 2019 ; pp. $299-331$.

260. Panich, N.; Sun, Y. Mechanical characterizati on of nanostructured $\mathrm{TiB}_{2}$ coatings using microscratch techniques. In Tribology and Interface Engineering Series; Sinha, S., Ed.; Scratching of Materials and Applications; Elsevier: Amsterdam, The Netherlands, 2006; Volume 51, pp. 210-222.

261. Yao, H.-L.; Yang, G.-J. Cold Spray Processing for Micro-Nano Ceramic Coatings. In Advanced Nanomaterials and Coatings by Thermal Spray; Yang, G.-J., Suo, X., Eds.; Micro and Nano Technologies; Elsevier: Amsterdam, The Netherlands, 2019 ; pp. 119-169.

262. Yao, H.-L.; Ma, J.-H.; Yang, G.-J.; He, X.-L.; Fan, S.-Q.; Li, C.-X.; Li, C.-J. Nano-porous TiO2 layer using ultrafine nano-particles for the blocking layer in dye-sensitized solar cells. J. Nanosci. Nanotechnol. 2014, 14, 2829-2835. [CrossRef] [PubMed]

263. Bestetti, M.; Sacco, D.; Brunella, M.F.; Franz, S.; Amadelli, R.; Samiolo, L. Photocatalytic degradation activity of titanium dioxide sol-gel coatings on stainless steel wire meshes. Mater. Chem. Phys. 2010, 124, 1225-1231. [CrossRef]

264. Alzamani, M.; Shokuhfar, A.; Eghdam, E.; Mastali, S. Sol-gel fabrication and enhanced optical properties, photocatalysis, and surface wettability of nanostructured titanium dioxide films. Mater. Sci. Semicond. Process. 2013, 16, 1063-1069. [CrossRef]

265. Pustovalova, A.A.; Pichugin, V.F.; Ivanova, N.M.; Bruns, M. Structural features of n-containing titanium dioxide thin films deposited by magnetron sputtering. Thin Solid Film 2017, 627, 9-16. [CrossRef]

266. Ratova, M.; Klaysri, R.; Praserthdam, P.; Kelly, P.J. Visible light active photocatalytic C-doped titanium dioxide films deposited via reactive pulsed DC magnetron co-sputtering: Properties and photocatalytic activity. Vacuum 2018, 149, 214-224. [CrossRef]

267. Rezazadeh Sefideh, M.; Sadeghian, Z.; Nemati, A.; Mohammadi, S.P.; Mozafari, M. Effects of processing conditions on the physico-chemical characteristics of titanium dioxide ultra-thin films deposited by DC magnetron sputtering. Ceram. Int. 2015, 41, 7977-7981. [CrossRef]

268. Li, Y.; Ishigaki, T. Thermodynamic analysis of nucleation of anatase and rutile from $\mathrm{TiO}_{2}$ melt. J. Cryst. Growth 2002, $242,511-516$. [CrossRef]

269. Wang, Y.; Liu, J.; Guo, A. Moderate temperature compression incorporating plastic deformation and rearrangement in Al2O3$\mathrm{ZrO}_{2}$ ceramics. Ceram. Int. 2013, 39, 883-886. [CrossRef]

270. Qiao, J.; Jia, H.; Liaw, P.K. Metallic glass matrix composites. Mater. Sci. Eng. R Rep. 2016, 100, 1-69. [CrossRef]

271. Xu, X.; Wang, M.; Guo, A.; Tao, X.; Hu, X.; Liu, J. Plastic deformation promoted by phases separation in bulk amorphous $\mathrm{Al}_{2} \mathrm{O}_{3}-\mathrm{ZrO}_{2}-\mathrm{Y}_{2} \mathrm{O}_{3}$. Mater. Lett. 2016, 170, 15-17. [CrossRef]

272. Xu, X.; Wang, Y.; Guo, A.; Geng, H.; Ren, S.; Tao, X.; Liu, J. Enhanced plasticity by nanocrystallite in bulk amorphous $\mathrm{Al}_{2} \mathrm{O}_{3}-$ $\mathrm{ZrO}_{2}-\mathrm{Y}_{2} \mathrm{O}_{3}$. Int. J. Plast. 2016, 79, 314-327. [CrossRef]

273. Jaworski, R.; Pawlowski, L.; Roudet, F.; Kozerski, S.; Petit, F. Characterization of mechanical properties of suspension plasma sprayed $\mathrm{TiO}_{2}$ coatings using scratch test. Surf. Coat. Technol. 2008, 202, 2644-2653. [CrossRef]

274. Yamada, M.; Isago, H.; Nakano, H.; Fukumoto, M. Cold spraying of $\mathrm{TiO}_{2}$ photocatalyst coating with nitrogen process gas. J. Therm. Spray Technol. 2010, 19, 1218-1223. [CrossRef]

275. Sun, S.; Song, P.; Cui, J.; Liang, S. Amorphous $\mathrm{TiO}_{2}$ nanostructures: Synthesis, fundamental properties and photocatalytic applications. Catal. Sci. Technol. 2019, 9, 4198-4215. [CrossRef]

276. Sabbah, H. Effect of sputtering parameters on the self-cleaning properties of amorphous titanium dioxide thin films. J. Coat. Technol. Res. 2017, 14, 1423-1433. [CrossRef]

277. Randorn, C.; Irvine, J.T.S.; Robertson, P. Synthesis of visible-light-activated yellow amorphous photocatalyst. Int. J. Photoenergy 2008, 2008, e426872. [CrossRef]

278. Huang, J.; Liu, Y.; Lu, L.; Li, L. The photocatalytic properties of amorphous $\mathrm{TiO}_{2}$ composite films deposited by magnetron sputtering. Res. Chem. Intermed. 2012, 38, 487-498. [CrossRef]

279. Lyu, J.; Shao, J.; Wang, Y.; Qiu, Y.; Li, J.; Li, T.; Peng, Y.; Liu, F. Construction of a porous core-shell homojunction for the photocatalytic degradation of antibiotics. Chem. Eng. J. 2019, 358, 614-620. [CrossRef]

280. Ohtani, B.; Ogawa, Y.; Nishimoto, S. Photocatalytic activity of amorphous-anatase mixture of titanium(IV) oxide particles suspended in aqueous solutions. J. Phys. Chem. B 1997, 101, 3746-3752. [CrossRef] 
281. Kasinathan, K.; Kennedy, J.; Elayaperumal, M.; Henini, M.; Malik, M. Photodegradation of organic pollutants RhB dye using UV simulated sunlight on ceria based $\mathrm{TiO}_{2}$ nanomaterials for antibacterial applications. Sci. Rep. 2016, 6, 38064. [CrossRef] [PubMed]

282. Kanna, M.; Wongnawa, S. Mixed amorphous and nanocrystalline $\mathrm{TiO}_{2}$ powders prepared by sol-gel method: Characterization and photocatalytic study. Mater. Chem. Phys. 2008, 110, 166-175. [CrossRef]

283. Wioletta, S.; Agnieszka, B.; Marek, J.; Anna, G.; Marcin, W. Photocatalytic activity enhancement of low-pressure cold-sprayed TiO2 coatings induced by long-term water vapor exposure. J. Therm. Spray Technol. 2021. [CrossRef]

284. Zhou, S.; Bernard, C.A.; Ravi, K.; Saito, H.; Ichikawa, Y.; Ogawa, K.; Yin, S. Development and characterization of photocatalytic GaN coatings by cold spray process. J. Therm. Spray Technol. 2021, 30, 1294-1309. [CrossRef]

285. Winnicki, M.; Gibas, A.; Baszczuk, A.; Jasiorski, M. Low pressure cold spraying of TiO2 on acrylonitrile butadiene styrene (ABS). Surf. Coat. Technol. 2021, 406, 126717. [CrossRef]

286. Fan, S.Q.; Yang, G.J.; Li, C.J.; Liu, G.J.; Li, C.X.; Zhang, L.Z. Characterization of microstructure of nano-TiO2 coating deposited by vacuum cold spraying. J. Therm. Spray Technol. 2006, 15, 513-517. [CrossRef]

287. Vilardell, A.M.; Cinca, N.; Garcia-Giralt, N.; Dosta, S.; Cano, I.G.; Nogués, X.; Guilemany, J.M. In-vitro comparison of hydroxyapatite coatings obtained by cold spray and conventional thermal spray technologies. Mater. Sci. Eng. C 2020, 107, 110306. [CrossRef] [PubMed]

288. Vilardell, A.M.; Cinca, N.; Garcia-Giralt, N.; Dosta, S.; Cano, I.G.; Nogués, X.; Guilemany, J.M. Functionalized coatings by cold spray: An in vitro study of micro- and nanocrystalline hydroxyapatite compared to porous titanium. Mater. Sci. Eng. C 2018, 87, 41-49. [CrossRef]

289. Chen, Q.-Y.; Zou, Y.-L.; Chen, X.; Bai, X.-B.; Ji, G.-C.; Yao, H.-L.; Wang, H.-T.; Wang, F. Morphological, structural and mechanical characterization of cold sprayed hydroxyapatite coating. Surf. Coat. Technol. 2019, 357, 910-923. [CrossRef]

290. Guillem-Marti, J.; Cinca, N.; Punset, M.; Cano, I.G.; Gil, F.J.; Guilemany, J.M.; Dosta, S. Porous titanium-hydroxyapatite composite coating obtained on titanium by cold gas spray with high bond strength for biomedical applications. Colloids Surf. B Biointerfaces 2019, 180, 245-253. [CrossRef]

291. Sun, L.; Berndt, C.C.; Gross, K.A.; Kucuk, A. Material fundamentals and clinical performance of plasma-sprayed hydroxyapatite coatings: A review. J. Biomed. Mater. Res. 2001, 58, 570-592. [CrossRef] [PubMed]

292. Vilardell, A.M.; Cinca, N.; Dosta, S.; Cano, I.G.; Guilemany, J.M. Feasibility of using low pressure cold gas spray for the spraying of thick ceramic hydroxyapatite coatings. Int. J. Appl. Ceram. Technol. 2019, 16, 221-229. [CrossRef]

293. Hasniyati, M.R.; Zuhailawati, H.; Sivakumar, R.; Dhindaw, B.K. Optimization of multiple responses using overlaid contour plot and steepest methods analysis on hydroxyapatite coated magnesium via cold spray deposition. Surf. Coat. Technol. 2015, 280, 250-255. [CrossRef]

294. Mardare, C.C.; Hassel, A.W. Review on the versatility of tungsten oxide coatings. Phys. Status Solidi A 2019, $216,1900047$. [CrossRef]

295. Lee, H.Y.; Yu, Y.H.; Lee, Y.C.; Hong, Y.P.; Ko, K.H. Thin film coatings of WO3 by cold gas dynamic spray: A technical note. J. Therm. Spray Technol. 2005, 14, 183-186. [CrossRef]

296. Lee, H.Y.; Yu, Y.H.; Lee, Y.C.; Hong, Y.P.; Ko, K.H. Interfacial studies between cold-sprayed $\mathrm{WO}_{3}, \mathrm{Y}_{2} \mathrm{O}_{3}$ films and Si substrate. Appl. Surf. Sci. 2004, 227, 244-249. [CrossRef]

297. Chen, M.W.; Qiu, H.P.; Jiao, J.; Wang, Y.; Xie, W.J. High temperature oxidation behavior of silicon carbide ceramic. Key Eng. Mater. 2016, 680, 89-92. [CrossRef]

298. Seo, D.; Sayar, M.; Ogawa, K. SiO2 and MoSi2 formation on inconel 625 surface via SiC coating deposited by cold spray. Surf. Coat. Technol. 2012, 206, 2851-2858. [CrossRef]

299. Sriramulu, D.; Reed, E.L.; Annamalai, M.; Venkatesan, T.V.; Valiyaveettil, S. Synthesis and characterization of superhydrophobic, Self-cleaning NIR-reflective silica nanoparticles. Sci. Rep. 2016, 6, 35993. [CrossRef] [PubMed]

300. Polakiewicz, A.; Dodiuk, H.; Kenig, S. Super-hydrophilic coatings based on silica nanoparticles. J. Adhes. Sci. Technol. 2014, 28, 466-478. [CrossRef]

301. Yang, G.-J.; Li, C.-J.; Liao, K.-X.; He, X.-L.; Li, S.; Fan, S.-Q. Influence of gas flow during vacuum cold spraying of nano-porous $\mathrm{TiO} 2$ film by using strengthened nanostructured powder on performance of dye-sensitized solar cell. Thin Solid Films 2011, 519, 4709-4713. [CrossRef]

302. He, X.-L.; Yang, G.-J.; Li, C.-J.; Li, C.-X.; Fan, S.-Q. Room temperature cold sprayed $\mathrm{TiO}_{2}$ scattering layer for high performance and bending resistant plastic-based dye-sensitized solar cells. J. Power Sources 2014, 251, 122-129. [CrossRef]

303. Patil, D.R.; Annapureddy, V.; Kaarthik, J.; Thakre, A.; Akedo, J.; Ryu, J. Piezoelectric thick film deposition via powder/granule spray in vacuum: A review. Actuators 2020, 9, 59. [CrossRef]

304. Zhang, S.-L.; Shang, Y.-B.; Li, C.-X.; Li, C.-J. Vacuum cold sprayed nanostructured $\mathrm{La}_{0.6} \mathrm{Sr}_{0.4} \mathrm{Co}_{0.2} \mathrm{Fe}_{0.8} \mathrm{O}_{3-\delta}$ as a high-performance cathode for porous metal-supported solid oxide fuel cells operating below $600{ }^{\circ} \mathrm{C}$. Mater. Today Energy 2021, 21, 100815. [CrossRef]

305. Wang, L.-S.; Li, C.-X.; Li, G.-R.; Yang, G.-J.; Zhang, S.-L.; Li, C.-J. Enhanced sintering behavior of LSGM electrolyte and its performance for solid oxide fuel cells deposited by vacuum cold spray. J. Eur. Ceram. Soc. 2017, 37, 4751-4761. [CrossRef]

306. Pradhan, D.; Sukla, L.B. Thin film of yttria stabilised zirconia on $\mathrm{NiO}$ using vacuum cold spraying process for solid oxide fuel cell. Int. J. Nano Biomater. 2017, 7, 38. [CrossRef] 
307. Lee, J.H.; Jang, H.L.; Lee, K.M.; Baek, H.-R.; Jin, K.; Hong, K.S.; Noh, J.H.; Lee, H.-K. In vitro and in vivo evaluation of the bioactivity of hydroxyapatite-coated polyetheretherketone biocomposites created by cold spray technology. Acta Biomater. 2013, 9, 6177-6187. [CrossRef]

308. Tang, J.; Zhao, Z.; Liu, H.; Cui, X.; Wang, J.; Xiong, T. A novel bioactive ta/hydroxyapatite composite coating fabricated by cold spraying. Mater. Lett. 2019, 250, 197-201. [CrossRef]

309. Liu, Y.; Dang, Z.; Wang, Y.; Huang, J.; Li, H. Hydroxyapatite/graphene-nanosheet composite coatings deposited by vacuum cold spraying for biomedical applications: Inherited nanostructures and enhanced properties. Carbon 2014, 67, 250-259. [CrossRef]

310. Liu, Y.; Hou, W.; Lupoi, R.; Yin, S.; Huang, J.; Li, H. Microscopic visualization of cell—Cold sprayed bio-coating interfaces: An intermediate layer formed during the culturing mediates the behaviors of the cells. Appl. Surf. Sci. 2020, 529, 147132. [CrossRef] 